\title{
Expedition 304/305 summary ${ }^{1}$
}

\author{
Expedition 304/305 Scientists ${ }^{2}$
}

\section{Chapter contents}

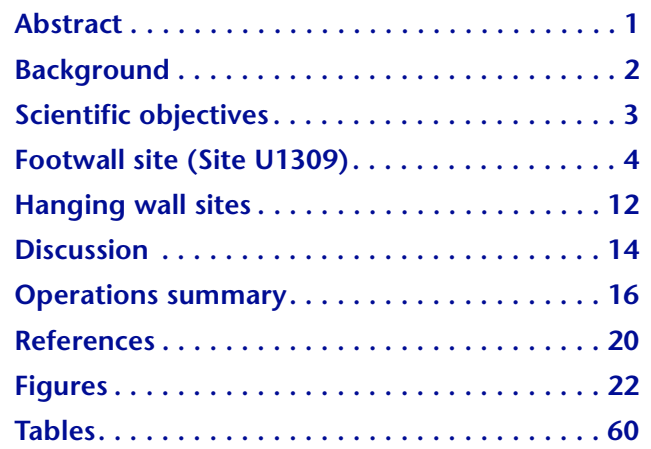

${ }^{1}$ Expedition 304/305 Scientists, 2006. Expedition 304/305 summary. In Blackman, D.K., Ildefonse, B., John, B.E., Ohara, Y., Miller, D.J., MacLeod, C.J., and the Expedition 304/305 Scientists, Proc. IODP, 304/305: College Station TX (Integrated Ocean Drilling Program Management International, Inc.). doi:10.2204/ iodp.proc.304305.101.2006

${ }^{2}$ Expedition 304/305 Scientists' addresses.

\section{Abstract}

Integrated Ocean Drilling Program Expeditions 304 and 305 composed a two-expedition program at Atlantis Massif, Mid-Atlantic Ridge $30^{\circ} \mathrm{N}$, designed to investigate the processes that control oceanic core complex formation and the exposure of ultramafic rocks in young oceanic lithosphere. Geophysical interpretations of unaltered mantle rock occurring $<1 \mathrm{~km}$ below the seafloor suggested we could drill through an alteration front in ultramafic rocks and obtain fresh mantle peridotite. In order to accomplish these objectives, we drilled at two sites: one in the footwall through an exposed detachment fault and one in the hanging wall. Drilling the fractured basalt in the hanging wall was thwarted by difficulties, whereas drilling in the footwall was very successful. The main hole at Site U1309 penetrated 1415.5 meters below seafloor, and recovery averaged $75 \%$. Igneous rocks recovered from the hole are the most primitive ever cored in slow-spreading ocean lithosphere and provide an exceptional record of magmatic and tectonic accommodation to extension in this environment.

The core recovered was dominantly crustal rock types: basalt $(\sim 3 \%)$ and gabbroic $(\sim 91 \%)$. A series of olivine-rich rocks $(\sim 5 \%$; dunites, wehrlites, troctolites), grouped as olivine-rich troctolites, part of which likely represent primitive cumulates, are interlayered with gabbroic rocks. A few thin mantle peridotite intervals are recognized in the upper $180 \mathrm{~m}$ of the section. Overall, the section is moderately altered at conditions ranging from granulite to zeolite facies. The rocks record initial alteration at low strains under granulite- and amphibolite-facies conditions and subsequent, more fully developed, lower temperature alteration (greenschist facies). Fault zone(s) comprising the detachment system must be highly localized to within tens of meters of the present-day seafloor. The existence of a fault at the top of the domal surface is supported by fragments of brecciated talc-tremolite fault schist and fractured metadiabase recovered in Hole U1309B and during the series of shallow cores drilled. Extensive amphibolite facies deformation is lacking, and high-strain ductile shear zones are rare. The absence of a thick, high-temperature ductile deformation zone in the footwall, and the apparent tectonic history (less rotation in the upper $180 \mathrm{~m}$ and variable rotations between several distinct, few-hundred meter sections downhole) suggested by paleomagnetic inclination measurements indicate complexity in structural evolution that differs from the simplest models of deeprooted detachment faults, predicted to be associated with high- 
temperature deformation, and with constant or monotonically varying footwall rotation with depth. Another challenge is that the central dome is clearly not an uplifted dominantly upper mantle section, as had been inferred prior to drilling. The exposures of peridotite along the southern wall of Atlantis Massif, the geophysical results suggesting at least portions of the dome contain fresh olivine-rich rock, and the downhole variability at Site U1309 all likely indicate significant lateral heterogeneity over short distances across the footwall.

\section{Background}

Atlantis Massif formed within the past 1.5-2 m.y., and it currently bounds the median valley on the western flank of the Mid-Atlantic Ridge (MAR) at $30^{\circ} \mathrm{N}$ (Fig. F1). The corrugated, striated central portion of the domal massif displays morphologic and geophysical characteristics inferred to be representative of a structural component of an oceanic core complex (OCC) exposed via long-lived detachment faulting (e.g., Cann et al., 1997; Blackman et al., 1998, 2004; Collins et al., 2001). The "core" of the complex comprises crust and possibly upper mantle rocks, denuded by a detachment fault exposed over an $8-10 \mathrm{~km}$ wide, $15 \mathrm{~km}$ long area that forms the elongate, doubly plunging domal seafloor morphology of Atlantis Massif. An adjacent basaltic block to the east is interpreted as the hanging wall to the detachment fault. A thin cover of variably lithified sediment, volcanic deposits, and rubble on the dome of the massif impedes seafloor mapping and sampling of the fault surface. The sediment-draped volcanic morphology and basalt sampled from scarps in the eastern block show its general character; the location of its contact with the dome can only be inferred from the break in slope. The detachment is inferred to dip beneath the seafloor at the base of the dome and to continue at a shallow angle $\left(<15^{\circ}\right)$ beneath the eastern block toward the present-day ridge axis.

Atlantis Massif shows significant along-axis variations in morphology; evolution of the southern portion of the massif may differ from that of the central dome. The Southern Ridge (Fig. F1) is shallower than the central dome, shoaling to $700 \mathrm{~m}$ below sea level (mbsl). There, the corrugated surface extends eastward to the top of the median valley wall. Exposures along the south face of the massif represent a cross section through the core complex and display a fault system as thick as $\sim 100 \mathrm{~m}$ (Schroeder and John, 2004). The serpentinization-driven Lost City hydrothermal vent field is just below the summit of the Southern Ridge (Kelley et al., 2001, 2005; Früh-Green et al., 2003).
Analysis of seismic refraction data (Fig. F2) at Atlantis Massif (Fig. F3A, F3B) (Collins and Detrick, 1998; Collins et al., 2002) indicates that velocities of $\sim 7.5$ $8 \mathrm{~km} / \mathrm{s}$ may occur within several hundred meters below seafloor at least locally in parts of the core of the massif. The gradient of seismic velocity in at least parts of the central dome of Atlantis Massif is shown to be similar to that determined (Collins et al., 2001) near Ocean Drilling Program (ODP) Site 920, where 100-200 m of serpentinized peridotite was drilled. The determined gradient is quite distinct from that characterizing gabbro-hosted Atlantis Bank (Southwest Indian Ridge) and other sections of the MAR.

Interpretation of multichannel seismic (MCS) reflection data (Fig. F2) suggests a major difference in structure between the outside (conjugate) corner lithosphere versus that hosting Atlantis Massif (Canales et al., 2004). The Layer $2 \mathrm{a} / 2 \mathrm{~b}$ boundary is quite clear on the eastern flank of the ridge axis, but it is not evident on the western flank across the massif. A strong reflector is visible at $0.2-0.5 \mathrm{~s}$ below much of the domal surface (Fig. F3C, F3D) and coincides roughly with the depth below which mantle velocities $(\sim 8 \mathrm{~km} / \mathrm{s})$ are inferred from the seismic refraction data. One interpretation suggests that the reflector marks an alteration front within the peridotite-dominated massif (Canales et al., 2004).

Modeling of sea-surface gravity (Fig. F4) and sparse seafloor data (Blackman et al., 1998, 2004; Nooner et al., 2003) suggest that rocks beneath the central and southern dome have densities $200-400 \mathrm{~kg} / \mathrm{m}^{3}$ greater than the surrounding rock. Results from a twodimensional model support the interpretation that the footwall is overlain by tilted hanging wall blocks capped by rocks with density typical of the upper crust $\left(2.5-2.7 \mathrm{~kg} / \mathrm{m}^{3}\right)$. The interface between the model blocks in the east is a gently inclined $\left(15^{\circ}-\right.$ $25^{\circ}$ ) boundary that dips more steeply than the exposed corrugated surface $\left(\sim 11^{\circ}\right)$ where it meets that hanging wall, possibly coinciding with the base of a fractured, highly altered detachment fault zone.

In situ rock samples (Fig. F2) from scarps, side-scan imagery, and gravity data suggest that the majority of the hanging wall block is composed of erupted basalt. Seismic data show a discontinuous but persistent reflector $0.2-0.5 \mathrm{~s}$ beneath the seafloor, which Canales et al. (2004) suggest coincides with the projection of the corrugated slope beneath the western edge of the hanging wall block. Canales et al. (2004) interpret this reflector to be the unexposed detachment fault. Assuming an average velocity of $4 \mathrm{~km} / \mathrm{s}$ in fractured basalt, the reflector is predicted to occur at 200-300 meters below seafloor (mbsf) at the hanging wall drill site. 
Rock samples collected by the manned submersible Alvin from the central dome are dominated by angular talus and rubble of serpentinized peridotite, metabasalt, and limestone (Cann et al., 2001; Blackman et al., 2004). A few samples from the central dome show cataclastic deformation or are highly serpentinized and/or metasomatically altered peridotite. The protolith of most of the serpentinite sampled on the south wall of the Southern Ridge is harzburgite. Highly altered gabbroic veins composed dominantly of talc, tremolite, and chlorite commonly cut these rocks (Früh-Green et al., 2001; Schroeder et al., 2001). Talc-rich fault rocks preserve textural and geochemical characteristics of their ultramafic protoliths (Boschi et al., 2006). Low-temperature seafloor weathering and carbonate vein formation mark the youngest phases of alteration in these samples.

Microstructural analysis of samples from the south wall of the Southern Ridge indicates shear deformation and dilational fracturing at metamorphic conditions ranging from granulite to subgreenschist facies (Schroeder et al., 2001). Ductile fabrics in peridotite samples are overprinted by semibrittle and brittle deformation (Schroeder and John, 2004). Stable mineral assemblages of tremolite, chlorite, and chrysotile indicate that the latter processes occurred at temperatures $<400^{\circ} \mathrm{C}$. The distribution of samples suggests that strong semibrittle and brittle deformation is concentrated at shallow structural levels $(<90 \mathrm{~m}$ beneath the domal surface) along the Southern Ridge (Schroeder and John, 2004). Outcrop mapping with the Alvin and photomosaics constructed from Argo digital still camera images show that this uppermost surface extends across much of the top of the Southern Ridge (Karson, 2003).

Only a few expeditions in the history of scientific ocean drilling have recovered lower crust and upper mantle rocks near a mid-ocean ridge axis (Fig. F5). During Deep Sea Drilling Project (DSDP) Leg 37 (Aumento, Melson, et al., 1977), 10 m of interlayered gabbro, olivine gabbro, and serpentinized peridotite were recovered at Site $1334\left(37^{\circ} \mathrm{N}\right.$; FAMOUS area) During DSDP Leg 45 (Melson, Rabinowitz, et al., 1979) on the western flank of the MAR south of the Kane Fracture Zone (MARK), a 587.9 m deep hole was drilled into sediments and basaltic basement. A few gabbro cobbles were recovered from the top of the core, and two serpentinized harzburgite and lherzolite cobbles were trapped between basaltic units. The drilling plan for DSDP Leg 82 (Bougault, Cande, et al., 1985) was designed to address regional variations in basalt chemistry along the ridge axis at three sites (Sites 556, 558, and 560) between $34^{\circ} 43^{\prime} \mathrm{N}$ and $38^{\circ} 56^{\prime} \mathrm{N}$; a few tens of meters of metamorphosed gabbro and pervasively serpentinized peridotite were recovered. During ODP Leg 109 (Detrick, Honnorez, Bryan, Juteau, et al., 1988), the first intentional drilling for mantle peridotites at a mid-ocean ridge at ODP Site 670 was completed with 7\% recovery of sepentinized peridotite. Figure F5 shows all holes (recovery $=>5 \%$ ) in upper mantle and lower crustal rocks drilled to date at or near mid-ocean ridges during nine different ODP and Integrated Ocean Drilling Program (IODP) expeditions. ODP Leg 147 (Gillis, Mével, Allan, et al., 1993) is the only deep crustal drilling program that took place in crust created at a fast-spreading ridge (Hess Deep, East Pacific Rise).

Atlantis Massif is the fourth location where drilling an inside corner high and/or a corrugated dome at a slow-spreading ridge has been attempted by ODP or IODP. A total of 16 holes ( $>10 \mathrm{~m}$ deep) were cored at 8 different sites in 3 different locations-Atlantis Bank, Southwest Indian Ridge, $57^{\circ} 16^{\prime} \mathrm{W}$; MARK, $23^{\circ} 32^{\prime} \mathrm{N}$; and MAR, $15^{\circ} 44^{\prime} \mathrm{N}$-during ODP Legs 118 , 153, 176, and 209 (Robinson, Von Herzen, et al., 1989; Cannat, Karson, Miller, et al., 1995; Dick, Natland, Miller, et al., 1999; Kelemen, Kikawa, Miller, et al., 2004). In all of these holes, the dominant rock type recovered is gabbroic and ranges from diabase to troctolitic in composition. The maximum distance between two holes in each of these regions is $2.8 \mathrm{~km}$ (MARK), $1.3 \mathrm{~km}$ (Atlantis Bank), $900 \mathrm{~m}$ (MAR $15^{\circ} 44^{\prime} \mathrm{N}$ ), and $20 \mathrm{~m}$ (Atlantis Massif).

\section{Scientific objectives}

Atlantis Massif has several key features that make it an ideal target for drilling an OCC:

- Its young age (<2 m.y. old) indicates that seafloor weathering and erosion have not degraded (macro-)structural relationships;

- The hanging wall is interpreted to be in contact with the footwall of the detachment; and

- Mantle seismic velocities have been interpreted to be present at several hundred meters depth below seafloor of the domal core (Fig. F3), potentially affording access to fresh in situ peridotite with conventional drilling.

The scientific objectives address fundamental questions related to (1) the nature and evolution (alteration) of the oceanic lithosphere accreted at slowspreading ridges and (2) the formation of OCCs.

The hypotheses tested by drilling during Expeditions 304 and 305 include the following:

- A major detachment fault system controlled the evolution of Atlantis Massif;

- Plate flexure (rolling hinge model) is the dominant mechanism of footwall uplift; 
- The nature of melting and/or magma supply contributes to episodes of long-lived lithospheric faulting;

- Expansion associated with serpentinization contributes significantly to uplift of the massif core;

- The Mohorovicic discontinuity (Moho) at Atlantis Massif is a hydration front; and

- Positive gravity anomalies at Atlantis Massif indicate relatively fresh peridotite.

If long-lived normal faulting and displacement are responsible for the evolution of the massif, uplift of the core may be the result of isostatic adjustment (Vening Meinesz, 1950) and thin-plate flexure (Spencer, 1985; Wernicke and Axen, 1988; Buck, 1988; Lavier et al., 1999; Buck et al., 2005). Differential rotation between the footwall and hanging wall blocks is predicted by thin-plate theory, so we can apply results from Expeditions 304 and 305 to investigate whether either the core and/or logging data show evidence of such history. Logging data provide continuous (oriented) images of fracture patterns in the borehole wall. These can be compared with fractures and veins measured in the cores from the same depth interval. Paleomagnetic inclination data are incorporated to determine any history of rotation of the footwall to depths $>1 \mathrm{~km}$. The pressure-temperature evolution of alteration reflects the tectonic and magmatic history as well, with cooling rates and water/rock ratios being controlled by intrusions, the amount of unroofing, and the degree of fracturing.

All detachment models predict that hanging wall rocks initially reside structurally above the footwall. If this is the case, petrologic and geochemical results may show a genetic relationship between footwall rocks and basalts of the hanging wall, dependent on the longevity and/or magnitude of fault slip.

Finally, the processes responsible for the development of OCCs appear to be episodic, with one factor being the level or style of magmatic activity at the local spreading center. Detailed study of the igneous sequence and structural relationships therein will be used to address the evolution of melting, intrusion, and cooling during the formation of Atlantis Massif. Comparison of our findings with those from ODP Legs 118/176, 153, and 209 will provide a means for assessing the similarities and differences in conditions that prevailed at the slow-spreading centers where the lithosphere drilled at these sites was initially formed.

\section{Footwall site (Site U1309)}

Site U1309 is located on the central dome of Atlantis Massif, 14-15 km west of the median valley axis of the MAR, where the seafloor coincides with what is interpreted to be a gently sloping, corrugated detachment fault surface (Figs. F1, F2). Two drill holes at this site (Holes U1309B and U1309D) penetrate a multiply intruded and faulted crustal section, providing core that documents the interplay between magmatism, deformation, and hydrothermal alteration prior to, during, and subsequent to a period of footwall displacement and denudation associated with detachment faulting. Five shallow-penetration holes (Holes U1309A and U1309E-U1309H) were designed to sample the sedimentary carapace and upper few meters of basement, to test the hypothesis that the upper surface coincides with a detachment fault, and to help constrain the temporal history of denudation. Collected sedimentary deposits may provide constraints on the timing of exposure across the dome based on the age and isotopic character of preserved microfossils. Basement rock sampled in these short holes provides initial information on deformation and alteration within the exposed fault and, perhaps, rock adjacent to the fault zone.

Site selection was based on a combination of geological and geophysical data (Figs. F2, F3, F4), balancing the details of seafloor character with larger scale objectives attainable if deep penetration of the footwall was successful. Centered within the gently sloping, morphologically corrugated, striated dome (Cann et al., 1997), the site coincides with gravity anomaly and seismic velocity maxima that indicate unaltered ultramafic rocks are likely to be present within several hundred meters of the seafloor (Blackman et al., 1998; Collins et al., 1998, 2001). Argo II imagery and Alvin dive mapping previously showed that the seafloor is covered by a thin layer of unconsolidated sediment deposited on bedrock and interrupted in places by lineated rubble fields (Blackman et al., 2004). In areas without significant loose sedimentary cover, a thin cover of lithified carbonate caps the underlying low-relief basement. Dredge and Alvin sampling (Fig. F2) indicate that loose, angular fragments on the central dome include low-grade metabasalt and serpentinite (Blackman et al., 1998, 2004).

Site U1309 comprises eight holes drilled within $2 \mathrm{~km}$ of one another along a spreading-parallel corridor (Fig. F2). The first five holes, Holes U1309A-U1309E, are located within $30 \mathrm{~m}$ of each other in an area with 2-4 $\mathrm{m}$ of unconsolidated sedimentary deposits above basement. A $60 \mathrm{~m} \times 50 \mathrm{~m}$ survey with the vibrationisolated television camera on the drill string documented a $\sim 2000 \mathrm{~m}^{2}$ area where both a single-bit pilot hole and a deep-penetration hole could be initiated within an area free of cobble- to boulder-sized rubble. The area is $\sim 280 \mathrm{~m}$ south of an Argo II track (run 039) and an Alvin dive (3642), both from cruise AT3- 
60 (Blackman et al., 2004), just south of NOBEL Line 10 and west of EW0102 MCS Line Meg-4 at common midpoint 4100 (Canales et al., 2004) (Fig. F3). Towed ocean-bottom instrument (TOBI) and DSL120 sidescan sonar data show spreading-parallel striations crossing this area. A gentle northeast slope coincides with the northern flank of the corrugation that the site penetrates. Principal geologic results from the pilot and deep-penetration holes are presented in subsequent sections.

The series of shallow-penetration holes included in this footwall site are located adjacent to, $280 \mathrm{~m}$ northwest of, and $1.6 \mathrm{~km}$ northeast of the deep hole (Hole U1309D). The motivation for this series of holes was twofold: first, to check for possible fossils or isotopic signatures in the sedimentary deposits to constrain the exposure age of the hypothesized detachment fault and, second, to attempt recovery of possible fault rock at the top of the domal surface. The first shallow-penetration core was obtained in Hole U1309A. Overcoring in the top interval of the deep-penetration holes (Holes U1309B and U1309D) precluded meaningful recovery of the sedimentary deposits and the upper $20 \mathrm{~m}$ of basement immediately below. Additional shallow-penetration holes were drilled in an effort to achieve that goal (Holes U1309E-U1309H).

\section{Hole U1309A}

Before initiating coring in Hole U1309A $\left(30^{\circ} 10.11^{\prime} \mathrm{N}\right.$, $42^{\circ} 07.11^{\prime} \mathrm{W} ; 1642 \mathrm{mbsl}$ ), we obtained a temperature measurement and seawater sample for microbiology and geochemistry. Bottom water at this site has temperature $=5.33^{\circ} \pm 0.6^{\circ} \mathrm{C}, \mathrm{pH}=7.73$, alkalinity $=2.16$ $\mathrm{mM}$, and salinity $=35.5 \mathrm{~g} / \mathrm{kg}$. These values are typical for the water depth and north central Atlantic location of the site (Levitus and Boyer, 1994). A push core in Hole U1309A recovered $2.0 \mathrm{~m}$ of unlithified tacky mud above bedrock. This microfossil ooze (with foraminifers and pteropods) includes mineral grains (fresh olivine and pyroxene) and fish remains. A sample of sediment for microbiological study was collected from Section 304-U1309A-1R-2, 48-60 cm, $\sim 20 \mathrm{~cm}$ above basement.

\section{Hole U1309B}

In an effort to assess drilling conditions and begin geologic characterization of the expected detachment fault zone, a single-bit pilot hole was drilled at Site U1309. Hole U1309B, initiated at the same location as Hole U1309A, was cored to 101.8 mbsf. Recovery was good (overall average $=46 \%$ ), increasing significantly (to an average of $52 \%$ for $30-100 \mathrm{mbsf}$ ) below the upper, very slow drilling $25 \mathrm{~m}$. The hole deviates from vertical by $7^{\circ}$ toward the northeast, and this was probably a factor in the reduced quality for some of the downhole logging measurements (see "Downhole measurements" in the "Site U1309" chapter).

\section{Hole U1309C}

The attempt to set casing for the hard rock reentry system (HRRS) was not successful in Hole U1309C $\left(30^{\circ} 10.11^{\prime} \mathrm{N}, 42^{\circ} 7.12^{\prime} \mathrm{W} ; 1638 \mathrm{mbsl}\right)$. The hole was abandoned with $\sim 25 \mathrm{~m}$ of $13 \frac{3}{8}$ inch casing pipe standing above the seafloor; it is $20 \mathrm{~m}$ east of Hole U1309B and $\sim 30$ m southwest of Hole U1309D.

\section{Hole U1309D}

Drilling in Hole U1309D $\left(30^{\circ} 10.12^{\prime} \mathrm{N}, 42^{\circ} 07.11^{\prime} \mathrm{W}\right.$; $1645 \mathrm{mbsl}$ ) took place over four periods for a total of 15 days during Expedition 304 and 34 days during Expedition 305. The hole was spudded using a hammer drill with $13 \frac{3}{8}$ inch casing in an effort to provide stable reentry for a deep hole. No rock was recovered in the upper $20.5 \mathrm{~m}$ of the hole. Below 20.5 mbsf, coring was accomplished using a rotary core barrel (RCB) bit. Despite rough sea conditions during some of the drilling, recovery rates were generally very good. The section from 108 to 126 mbsf (Cores 304-U1309D-18R through 21R) had very low recovery, including one empty core barrel and a second with only $14 \%$ recovery. Logging data suggest this low-recovery zone may coincide with a fault zone. Aside from the low-recovery interval and the upper $20.5 \mathrm{~m}$, recovery rates averaged $68 \%$ in the upper 400 mbsf (Expedition 304). As drilling conditions in the pilot hole (Hole U1309B) were very good, casing below $20 \mathrm{~m}$ in Hole U1309D was deemed unnecessary. This gave us time to core the upper $\sim 130 \mathrm{~m}$ during our initial occupation of the hole, providing an opportunity to assess cross-hole correlation of lithologic units and structure between Holes U1309B and U1309D. The second period of coring followed drilling at Sites U1310 and U1311 and deepened the hole to 401.3 mbsf before the first logging run in Hole U1309D completed the work of Expedition 304. After coring to a depth of $\sim 840$ mbsf during Expedition 305 , a second logging run was completed. Final coring penetrated to $1415.5 \mathrm{mbsf}$ and was followed by the third set of downhole logging measurements at the end of Expedition 305. Total recovery in Hole $\mathrm{U} 1309 \mathrm{D}$ is $1043.3 \mathrm{~m}$ (average $=75 \%$ below the upper $\sim 20 \mathrm{~m}$ ).

\section{Hole U1309E}

Hole U1309E $\left(30^{\circ} 10.12^{\prime} \mathrm{N}, 42^{\circ} 07.11^{\prime} \mathrm{W} ; 1645 \mathrm{mbsl}\right)$ was offset $10 \mathrm{~m}$ east of Hole U1309D for an attempt to recover the sediment and upper meter of base- 
ment using the RCB. Disrupted sediments were obtained, as were several fragments of metabasalt.

\section{Hole U1309F}

The next attempt at shallow penetration was made in Hole U1309F $\left(30^{\circ} 10.20^{\prime} \mathrm{N}, 4^{\circ} 07.25^{\prime} \mathrm{W} ; 1645\right.$ mbsl), $280 \mathrm{~m}$ to the northwest of Hole U1309D in an area where unconsolidated sedimentary deposits are less widespread than in Holes U1309A-U1309E and lithified carbonate cap rock was mapped with the Alvin and the Argo II during cruise AT3-60 in 2000. A brief camera survey confirmed the basic setting, although some loose sediment occurred within a few meters of the first contact of the drill bit at the seafloor. Despite clear indications that we drilled $>1$ $\mathrm{m}$ into hard rock, recovery included only disrupted sediment and a few fragments of metabasalt. No chips of lithified carbonate were recognized. We discontinued RCB shallow-penetration attempts and switched to the extended core barrel (XCB) bit for a further attempt (Hole U1309G).

\section{Hole U1309G}

Hole U1309G $\left(30^{\circ} 10.54^{\prime} \mathrm{N}, 42^{\circ} 06.32^{\prime} \mathrm{W} ; 1872 \mathrm{mbsl}\right)$ was sited $1.6 \mathrm{~km}$ northeast of Hole U1309D in an area characterized by a broad region of variably lithified carbonate deposits above basement. A brief camera survey confirmed this assessment, and the hole was located within sight of a marker left by the Alvin in 2000. The hole was spudded into stepped and platy lithified carbonate sediment. Coring to $3.5 \mathrm{~m}$ using an XCB bit recovered $0.91 \mathrm{~m}$ of microfossil ooze with three thin $(2-3 \mathrm{~cm})$ interlayers of basaltic hyaloclastite. Glass from the hyaloclastite is oxidized palagonite. No lithified carbonate or intact basement rock was recovered. The sequence of fossiliferous ooze, hyaloclastite, and a clayey material with rounded, largely metabasalt clasts may provide useful postexposure data. The latter could be a sedimentary conglomerate, but we cannot rule out significant reworking due to drilling in this lowermost interval.

\section{Hole U1309H}

A second attempt at basement recovery from a shallow-penetration hole at the same location as Hole U1309G was possible when logging activities in Hole U1309D were stopped early because of logging tools sticking in the borehole. Rather than risk either tools or hole, the remaining time on site was used to RCB core a few meters at essentially the same location as Hole U1309G. This eliminated the need for a camera survey. Drilling for $4 \mathrm{~h}$ penetrated to $4 \mathrm{mbsf}$; recovery from this hole was $0.19 \mathrm{~m}$ and included pieces of basalt and talc-tremolite schist along with one piece of diabase cataclasite (Fig. F6). Despite the small return, these samples are significant. The talc-tremolite schist is similar to fault rocks recovered near the top of the Southern Ridge at Atlantis Massif (Schroeder and John, 2004) and at $15^{\circ} 45^{\prime} \mathrm{N}$ on the MAR (Escartin et al., 2003). Fracture intensity in the diabase is minor, suggesting fairly low strain, but consistent with the sample being part of a process zone associated with a fault system. Although these samples are minimal, they provide direct evidence that the corrugated central dome of Atlantis Massif is an exposed detachment, consistent with the $50-100 \mathrm{~m}$ thick brittle deformation zone described along the top of the south face of the massif (Schroeder and John, 2004; Karson et al., 2005). An Alvin sample within this spreading-parallel corridor on the central dome showed similar talc rock (Blackman et al., 2004) and there were a few chips of talc-tremolite schist in the top core from Hole U1309B, but neither of these latter samples could be proven to be in place.

\section{Igneous sequence petrology and geochemistry}

A total of 770 igneous units were defined in Hole U1309D during Expeditions 304 and 305. Each unit is distinguished on the basis of primary modal mineralogy, igneous contacts, and variations in grain size.

The most abundant rock type is from the gabbro group (Fig. F7), comprising $55.7 \%$ of the core recovered from Hole U1309D. This group spans a wide range in modal composition, including minor (rarely exceeding a few percent) amounts of olivine, Fe-Ti oxides, and/or orthopyroxene. Gabbroic rocks from Hole U1309D exhibit significant variations in grain size from microgabbro (crystals $<1 \mathrm{~mm}$ ) to seriate medium-grained gabbro to pegmatitic gabbro (grain size $>10 \mathrm{~cm}$ ), in places within a single section of core. Gabbronorite and orthopyroxene-bearing gabbro are included in this group. Because unambiguous identification of orthopyroxene requires careful thin section observation, the amount of orthopyroxenebearing gabbro is a minimum estimate (see "Igneous petrology" in the "Site U1309" chapter). Gabbronorites show the same textural relationships as the associated gabbros. In the lower part of Hole U1309D (Cores 305-U1309D-243R through 272R), low-Ca pyroxene appears as orthopyroxene and/or inverted pigeonite.

Olivine gabbro is the second most abundant rock type recovered from Hole U1309D (25.5\%), with modal olivine varying widely $(>5 \%)$. The modal composition of this rock type is highly variable on a 
submeter scale and locally grades into troctolitic gabbro.

Troctolite is commonly spatially associated with olivine and troctolitic gabbros, but it is less common, constituting only $2.7 \%$ of the rocks recovered (Figs. F7, F8). The texture of troctolite is irregularly seriate, locally with poikilitic clinopyroxene. Troctolite units are commonly intruded by late-stage dikes of both coarse-grained gabbro and microgabbro.

Olivine-rich rocks with relatively low modal plagioclase and clinopyroxene, including dunite, wehrlite, and troctolite, are grouped as olivine-rich troctolite (see "Igneous petrology" in the "Site U1309" chapter). They represent $5.4 \%$ of the recovered rocks in Hole U1309D, with the thickest interval between 1092 and 1236 mbsf (Fig. F7). The olivine-rich troctolites contain $>70 \%$ olivine by mode and are commonly intercalated with olivine and troctolitic gabbro (Fig. F9). In contrast to troctolite, olivine-rich troctolite displays subhedral to rounded mediumgrained olivine and interstitial to poikilitic plagioclase and clinopyroxene in variable proportions (Fig. F10).

Two short intervals of ultramafic rock were recovered in the upper $100 \mathrm{~m}$ of both Holes U1309B and U1309D (Fig. F9C). Four intervals of serpentinized peridotite (three of which are clearly in place) at $\sim 61$, $132.5,172-173$, and 224 mbsf were recovered in Hole U1309D and include both lherzolite and dunite. Peridotites from Hole U1309B ( 58 mbsf) have $\mathrm{Mg} \#$ of 90-91. The low $\mathrm{CaO}$ and $\mathrm{Al}_{2} \mathrm{O}_{3}$ contents of the peridotites suggest that, prior to alteration, they were more refractory than those collected during Leg 153 at $23^{\circ} \mathrm{N}$ on the MAR (Casey, 1997).

Oxide gabbro, defined by the presence of $>2 \%$ modal Fe-Ti oxide minerals, makes up $7 \%$ of the rocks recovered from Hole U1309D (Fig. F7). The most common occurrence of oxide minerals $(\sim 80 \%$ of the oxide gabbros) is as randomly dispersed patches in undeformed, generally coarse grained gabbro (Fig. F11A, F11B). Concentrations of oxide minerals are also present as discrete dikelets/layers cutting other rock types with either sharp or diffuse boundaries. Additionally, oxide mineral concentrations are associated with intervals of ductile deformation (Fig. F11C, F11D). Many oxide gabbros contain apatite and zircon as accessory minerals. Common occurrences of oxide gabbros were also noted in Hole 735B, Atlantis Bank (Dick, Natland, Miller, et al., 1999); in the MARK area (Leg 153; Cannat, Karson, Miller, et al., 1995); and at $15^{\circ} \mathrm{N}$ at the MAR (Leg 209; Kelemen, Kikawa, Miller, et al., 2004).

Where visible, contact relations between gabbro and other rock types (except diabase) at Site U1309 sug- gest that gabbro is generally intrusive into more olivine rich rock types (olivine gabbro and troctolite) and that it is in turn intruded by felsic ("leucocratic") dikes and oxide gabbro. These relationships are more common between 400 and 650 mbsf than in the lower part of the hole, where gabbro contacts are commonly more diffuse. Contact relations between troctolite and gabbro range from sharp, where thin intervals of gabbro crosscut the serpentine foliation in troctolite, to gradational, where thicker intervals of gabbro are present. Contacts between oxidebearing rock types and gabbro range from sharp to gradational over centimeters. Felsic dikes in gabbro generally show sharp contacts, but varying degrees of high-temperature reaction between dikes and wallrocks are also observed. These reaction zones commonly have oriented minerals such as oxides, pyroxenes, or plagioclase growing along and across them, suggesting postemplacement reaction.

Holes U1309B and U1309D have interfingered units that vary in thickness from centimeters up to $~ 100$ $200 \mathrm{~m}$ where intrusive contacts are preserved. The $\sim 140$ m thick interval of olivine-rich troctolite from 1094 to 1236 mbsf in Hole U1309D forms an integral lithologic package. The olivine-rich troctolites and minor associated lithologic units that this package comprises have been intruded by numerous crosscutting gabbroic dikes of variable thickness at temperatures below the troctolite solidus. Broader scale contacts with adjacent olivine gabbro appear to be dominantly intrusive and formed under hypersolidus conditions. Interstitial clinopyroxene appears more abundant adjacent to gabbroic dikes, suggesting that oikocrystic clinopyroxene recrystallized during intrusion of the crosscutting dikes.

Diabase intrudes other rock types in several places throughout Holes U1309B and U1309D (Fig. F7C, F7D). The intrusive contacts in Hole U1309B and the upper $130 \mathrm{~m}$ of Hole U1309D, taken with the relative intensity of alteration and vein development, suggest that the diabase bodies were emplaced late in the intrusive history of the footwall at Site U1309. Subhorizontal magmatic foliations, together with paleomagnetic and logging data, suggest that diabase in Holes U1309B and U1309D forms groups of subhorizontal sheets or sills. Unit boundaries are locally marked by chilled margins, and in some cases magnetic susceptibility (MS) increases systematically toward the top and base of a unit (Fig. F12). Together, these observations suggest individual diabase sheet thicknesses on the order of 2-8 $\mathrm{m}$.

Nearly all gabbroic rock types recovered from Site U1309 are cut by veins/dikes (Fig. F13) of variable thickness and composition. These veins and/or dikes range in composition between gabbro, oxide-bearing 
gabbro, and trondhjemite and may be partly magmatic, partly metamorphic, partly deformationrelated, or the result of a combination of all three processes.

Among DSDP/ODP/IODP drill holes, Hole U1309D is unique in that it represents a section of primitive to somewhat evolved gabbroic rocks and includes intrusive diabase intervals as well as olivine-rich rocks, which may represent primitive cumulates. Gabbroic rocks from Site U1309 have compositions that are among the most primitive sampled by drilling along the MAR $\left(23^{\circ} \mathrm{N}\right.$ and $15^{\circ} 20^{\prime} \mathrm{N}$; Agar et al., 1997; Kelemen, Kikawa, Miller, et al., 2004) and on the Southwest Indian Ridge (SWIR; Hole 735B) (Dick, Natland, Miller, et al., 1999) (Fig. F14). This is reflected in $\mathrm{Mg}$ numbers ranging from 67 to 87 (Fig. F15) and low $\mathrm{TiO}_{2}(<0.72 \mathrm{wt} \%), \mathrm{Na}_{2} \mathrm{O}$, and trace element contents. Site U1309 gabbroic rocks can be interpreted as cumulates related to the basalt and diabase through crystal fractionation processes and a common parental magma.

Basalt and diabase from Site U1309 are tholeiitic basalts and minor basaltic andesite, with compositions that overlap basaltic glasses from the entire MAR (Fig. F16). All samples analyzed are slightly $\mathrm{CaO}$ and $\mathrm{Al}_{2} \mathrm{O}_{3}$ poor and $\mathrm{Na}_{2} \mathrm{O}$ rich compared to average MAR basaltic glass compositions. These differences may be related to the pervasive greenschist-facies alteration. All diabasic rocks show significant variation in incompatible trace elements, including $\mathrm{Y}$ and $\mathrm{Zr}$.

\section{Hydrothermal alteration, metamorphism, and metasomatism}

Alteration mineral assemblages in rocks from Site U1309 record cooling of mafic plutonic rocks from submagmatic conditions $\left(>1000^{\circ} \mathrm{C}\right)$ to the temperatures of zeolite facies $\left(<200^{\circ} \mathrm{C}\right)$ during the unroofing and uplift of Atlantis Massif. Individual samples generally display a range of superposed metamorphic conditions, but no single sample records the entire cooling history of the site. Alteration intensity is moderate, tends to decrease downcore, and is commonly related to the intensity of veining (Figs. F9, F17). Locally, there are exceptions to the decreasing alteration downhole where, for example, alteration intensity broadly correlates with the modal abundance of olivine in the intercalated olivine-rich troctolite, olivine gabbro, and gabbro recovered between $\sim 1090$ and $\sim 1240$ mbsf and in the lowermost gabbros and olivine gabbros. Coarser grained gabbro intervals are, in general, more altered than medium- to coarse-grained units. Intervals of olivine-rich troctolite show alteration restricted to heterogeneous serpentine networks, with strong alteration gradients from the contact with intensely veined intercalated gabbros to the fresher cores of the olivine-rich troctolite units (Fig. F17C). The latter locally contain intervals of very fresh (as low as 1\% serpentinization) olivine-rich (as much as $>90 \%$ ) rocks.

The metamorphic and alteration history recorded at Site U1309 is summarized as follows:

1. High-temperature, near-solidus, mylonitic deformation and recrystallization of plagioclase + clinopyroxene and brown amphibole at granulite to upper-amphibolite-facies conditions (Fig. F18).

2. Replacement of pyroxene by green to brown hornblende in diabase, gabbro (especially oxide gabbro), and mylonite zones. The extent of this largely static event is difficult to estimate because of a greenschist-facies overprint by amphibole and uncertainties over amphibole compositions in thin section.

3. A widespread, largely static upper-greenschist-facies to lower-amphibolite-facies metamorphism manifested by the following:

- Formation of secondary plagioclase and amphibole and, below 384 mbsf, epidote growth that appears to be related to late magmatic leucocratic intrusions.

- Replacement of pyroxene by actinolitic amphibole. This is the major effect of the greenschist event in most gabbroic rocks and diabase. In the upper $\sim 300 \mathrm{~m}$ of Hole U1309D, this alteration is pervasive and all samples are affected to some extent. At greater depths, the alteration is increasingly associated with the emplacement of amphibole-rich veins and accompanying halo alteration (Fig. F19).

- Development of tremolite-chlorite \pm talc corona texture in all rocks containing both olivine and plagioclase (Fig. F20). This may include some amphibolite-facies formation of cummingtonite and green hornblende. In the upper $300 \mathrm{~m}$ of Hole U1309D, this reaction proceeded to completion in almost all samples, removing either olivine or plagioclase from the assemblage. At greater depths, the reaction commonly did not proceed to completion and is increasingly localized by amphibole veins and the margins of gabbroic dikelets. At shallower levels, most amphibole veins postdate corona formation.

- Metasomatic talc-tremolite \pm chlorite veins and irregular zones in ultramafic rocks, especially near contacts with mafic rock (Fig. F21).

- Talc-tremolite schist with ultramafic protolith (upper $25 \mathrm{~m}$ of Holes U1309B and U1309D and fragments in Holes U1309E and U1309H) (Fig. F6). 
4. Static, lower greenschist to subgreenschist metamorphism that includes the following:

- Serpentinization in olivine gabbro, troctolite, and olivine-rich troctolite with concomitant formation of prehnite and hydrogrossular in associated plagioclase. Above $\sim 300 \mathrm{mbsf}$, serpentinization is restricted to rocks where olivine was in excess over plagioclase and was therefore still present after the corona-forming reaction went to completion. At deeper levels, serpentine, prehnite, and hydrogrossular are often localized on closely spaced, variably oriented fractures ("ladder veins"). The degree of serpentinization varies widely from $>90 \%$ to $<10 \%$ of the olivine. In the simplest case, serpentinization proceeds via the development of kernel texture (O'Hanley, 1996) (Fig. F22). A commonly observed feature in serpentinized rocks is the development of microfracture sets that radiate or extend into plagioclase from neighboring serpentinized olivine grains (Fig. F23). These fractures are commonly filled with chlorite and/or amphibole.

- Sporadic talc-carbonate metasomatic alteration of olivine-rich rocks.

- Relatively late emplacement of slip-fiber amphibole veins and associated local metasomatism.

- Serpentinization of isolated grains in olivine gabbro and relict grains in coronas.

- Zeolite-facies metamorphism that includes replacement of plagioclase by zeolites throughout the core and emplacement of zeolite-bearing veins below 700 mbsf (Fig. F24, F25). Late, open, irregular fractures commonly contain a clay mineral that may be saponite, along with carbonate and (below 700 mbsf) zeolite minerals.

\section{Structural relationships}

The majority of core recovered from Site U1309 records pervasive static alteration of the rocks and shows that pseudomorphs of igneous textures remain largely unmodified. Magmatic deformation fabrics (defined by the preferred orientation of plagioclase) were recorded in $22 \%$ of recovered rocks (Fig. F26). These fabrics are weak except in local intervals. Magmatic foliation tends to be better developed in finer grained gabbros than in coarser grained varieties; foliation is also well developed in the rare layered intervals. Textural observations suggest that some foliation may have been destroyed by late growth of pyroxene crystals reaching sizes as large as $20 \mathrm{~cm}$. Magmatic foliations typically dip $\sim 30^{\circ}-60^{\circ}$ but are steeper (e.g., at 400 and $560 \mathrm{mbsf}$ ) or more gently dipping (e.g., at 850 and $1150 \mathrm{mbsf}$ ) in local intervals. In many places, weak to moderate crystalplastic deformation seems to overprint magmatic foliations (Fig. F27), as also described in Hole 735B (Shipboard Scientific party, 1999). This deformation is commonly difficult to identify macroscopically but is evident in thin section.

High-strain crystal-plastic shear zones are rare (recorded in only $3 \%$ of the core). The highest densities of crystal-plastic shear zones are at 35-80 mbsf and 670-720 mbsf in Hole U1309D and are typically restricted to clearly defined, mostly granulite grade shear zones ranging in width from millimeters to a maximum of a few meters. Both normal and reverse senses of offset in the core reference frame are observed in such shear zones, and their dips are typically moderate but can be locally steep (e.g., at 700 mbsf). This is in marked contrast to the much larger number of high-strain shear zones recorded in Hole 735B on the SWIR, especially in the upper $500 \mathrm{~m}$ (Dick, Natland, Miller, et al., 1999; Dick et al., 2000).

Vein sets defined by mineralogy are found throughout the core. The earliest generation is late magmatic veins. Their occurrence broadly correlates with country rocks with a similar composition, suggesting local derivation (scale $=\sim 100 \mathrm{~m}$ ). Later generations of veins include dark green amphibolite-facies veins (consisting of amphibole) cut by pale green, fibrous greenschist-facies veins (actinolite/tremolite-chlorite \pm talc and epidote). Fiber orientations on the pale green veins are commonly subhorizontal (particularly deeper than $\sim 300 \mathrm{mbsf}$ ) independent of veindip, indicating strike-slip movement during formation. The latest (and lowest metamorphic grade) vein type is typically open, white veins (carbonate and sulfide \pm chlorite; prehnite), possibly associated with unloading. Gray veins (serpentine and chlorite) are spatially restricted to olivine-rich troctolite and both cut and are cut by serpentine foliation. In hand sample, such areas of intense serpentinization form a conspicuous but generally irregular foliation (Fig. F28) with orientations varying on a meter scale or from one piece of core to the next, and several crosscutting foliations developed in the same piece of core. Subsets of the gray veins have synkinematic fibers. Vein intensities tend to correlate with fault zones on a local scale (Fig. F29), though displacement on veins (vein faults) is not common. Vein intensities decrease significantly below 785 mbsf. The dip of veins is variable but moderate on average, irrespective of the vein type. On the scale of the entire core, there is no systematic, lithology-dependent downhole distribution pattern of specific vein types.

The amount of strain recorded by brittle fracture and cataclasis is negligible overall, except for fault zones 
concentrated in the upper $50 \mathrm{~m}$ of Hole U1309D, at 108-126 mbsf, and between 685 and 785 mbsf (Fig. F30), where the boundaries of structural units are defined (Fig. F29). Additional zones of significant cataclasite were found at 250 and 1100 mbsf. Cataclasis is locally associated with oxide gabbro intervals/ dikelets, leucocratic veins, and contact zones between diabase intrusions and their gabbroic host rocks. Crosscutting relationships indicate a complex succession of events involving fluid flow and deformation.

Structurally, core from Hole U1309D can be subdivided into three major units (Fig. F29):

- Structural Unit 1 (0-170 mbsf) is marked by a high but decreasing degree of cataclasis downhole; abundant, late, relatively undeformed diabase; a high degree of greenschist-grade alteration; and a near-present-day orientation of the paleomagnetic inclination. The boundary to structural Unit 2 at $\sim 170$ mbsf is marked by a subhorizontal to moderately dipping crystal-plastic shear zone within gabbroic rocks, a high intensity of veining, strong cataclasis, and a $\sim 2 \mathrm{~m}$ thick interval of altered ultramafic rocks.

- Structural Unit 2 extends from 170 to 785 mbsf. It is marked by a relatively high intensity of veining, including the presence of sulfides. Paleomagnetic inclinations are $\sim 10^{\circ}-30^{\circ}$ shallower than present-day values. Lithologically, structural Unit 2 is varied and nondistinct. The base of structural Unit 2 is defined by a series of greenschist-grade cataclastic fault zones occurring between 695 and 785 mbsf. There is a sharp decrease in whole rock $\mathrm{Mg \#}$ of the gabbros at $600 \mathrm{mbsf}$ (Fig. F15).

- Structural Unit 3 extends from this boundary to the bottom of Hole U1309D and is characterized by an overall low intensity of cataclastic deformation, veining, and plastic deformation.

Tentative reorientations of structures using paleomagnetic and logging data were performed on structural features from Holes U1309B and U1309D to $\sim 130$ mbsf. These data indicate that crystal-plastic foliations dip dominantly to the west, a majority of veins dip toward the east, and several faults strike east-west. Holes U1309B and U1309D are $20 \mathrm{~m}$ apart, and thus the local continuity of igneous, metamorphic, and structural units can be evaluated. On a broad scale, lithologic correlations between Holes U1309B and U1309D are possible, but correlation breaks down at a scale of $<10 \mathrm{~m}$ (see "Structural geology" in the "Site U1309" chapter).

The lack of significant structures indicative of high displacement by either ductile or brittle processes severely limits the possible thickness of fault zones that could comprise a detachment system over the central dome. Poor recovery of the upper $20 \mathrm{~m}$ of the footwall allows the possibility that this narrow zone accommodated very high strain along a brittle fault. Such extreme strain localization has been documented to occur associated with continental detachments (e.g., John, 1987; Miller, 1996). If this is the case here, the central dome differs from the Southern Ridge of Atlantis Massif, where seafloor mapping and sample analysis suggest a detachment zone thickness on the order of $50-100 \mathrm{~m}$ (Schroeder and John, 2004; Karson, 2003).

\section{Geophysical measurements}

Shipboard physical property data in combination with downhole logging data provide an initial means to assess which aspects of the geological characteristics of the domal core of Atlantis Massif might contribute to the regional geophysical data sets. In addition, inherent rock properties can be assessed and related to rock type and alteration.

MS is highest in the olivine-rich troctolites recovered from Hole U1309D but is quite low in most of the gabbros (Fig. F31). Both olivine-rich troctolite and oxide gabbro intervals can have very high MS signals (2,000-10,000 instrument units), although only the former is consistently at these levels. The olivinerich troctolites are variously serpentinized, with very strong local gradients, and the susceptibility reflects magnetite produced during the alteration process.

Natural remanent magnetization (NRM) of the rocks from Hole U1309D was determined on board following removal of the drilling-induced overprint. Alternating-field demagnetization (typically $30 \mathrm{mT}$ ) was used to remove the overprint, and the bulk of the archive-half sections show negative inclination direction (Fig. F29C), which corresponds to a reversed magnetic polarity epoch. Minicore samples, cleaned of overprint by either alternating-field (up to 100 $\mathrm{mT}$ ) or thermal demagnetization (to $500^{\circ}-550^{\circ} \mathrm{C}$ ), generally show very good agreement with the halfcore inclination patterns downhole. Five inclination groups have been identified based on remanence data from archive halves and discrete samples (Fig. F29C). The boundaries between these groups generally coincide with structural features (faults and shear zones), so structural data have been used to define the precise boundaries.

The upper $180 \mathrm{~m}$ is characterized by a mean discrete sample inclination $\left(-49^{\circ}\right)$ that is identical to the expected dipole inclination at the site (Fig. F29C). This suggests that from 0 to $180 \mathrm{mbsf}$ there has not been detectable tectonic rotation since the remanence was acquired, although it should be kept in mind that modest but significant $\left(\sim 20^{\circ}\right)$ counterclockwise rota- 
tion about a $10^{\circ}$ trending, horizontal axis (i.e., subparallel to the ridge axis) would produce no net change in the inclination of the remanent vector. In contrast, the mean inclinations from all inclination groups deeper than 180 mbsf in the hole are statistically distinct from the expected direction (Fig. F29C). The shallower inclinations in these sections cannot be attributed to artifacts of the drilling and/ or measurement process, as they are corroborated by numerous high-quality discrete sample demagnetization data. Inclination Groups III and IV have mean values steeper than those from Groups II and V. This nonsystematic change in remanence inclination downhole is difficult to reconcile with any simple model of denudation. Instead of the footwall behaving as a single block, it appears that different intervals (inclination Groups I-V) may have experienced different tectonic and/or alteration histories. Because structural boundaries generally coincide with the inclination group boundaries (Fig. F29), those deformation zones could provide a mechanism for variation in tectonic rotation within the footwall.

Multicomponent remanences were documented for a few samples in the upper $400 \mathrm{~m}$ of Hole U1309D, and this suggests that remanence acquisition spanned multiple polarity intervals. The highest stability reversed polarity magnetizations are typically shallower than the normal polarity overprint (Fig. F32), and the two components are not antipodal. These overprints, distinct from the steep, low-coercivity drilling-induced component, have a mean inclination $\left(53.6^{\circ}+6.4^{\circ} /-8.2^{\circ}\right)$ that is not statistically distinguishable from the present-day normal polarity inclination at the site. The difference between the normal and reversed polarity directions may reflect the influence of tectonic tilting after acquisition of the highest stability reversed polarity magnetization. Although less common, such multicomponent magnetizations are also observed in several discrete samples analyzed from the lower $1000 \mathrm{~m}$ of the hole.

The physical properties that are most relevant for relating the rocks from Hole U1309D to broader scale geophysical measurements are seismic velocity and density. Shipboard measurements provide an indication of the inherent properties of small samples at room temperature and pressure. Variability in the measured values can be due to a number of factors, including mineralogy, porosity, grain size, and the style and degree of alteration.

A significant change in several core sample and downhole logging properties occurs between $\sim 280$ and $\sim 350$ mbsf, across an interval dominated by serpentinized, olivine-rich rocks (Fig. F33). Density values have reduced scatter and slightly higher average values below $350 \mathrm{mbsf}$, increasing from $2.8 \mathrm{~g} / \mathrm{cm}^{3}$ in the interval $280-340$ mbsf to $2.9 \mathrm{~g} / \mathrm{cm}^{3}$ in the interval 350-400 mbsf. Average compressional velocity of minicore samples in the 280-340 mbsf interval drops to $5.3 \mathrm{~km} / \mathrm{s}$ (from $5.5 \mathrm{~km} / \mathrm{s}$ in the overlying $200 \mathrm{~m}$ ) before increasing to $5.7 \mathrm{~km} / \mathrm{s}$ at 340-400 mbsf. Logging compressional velocity increases from $\sim 5.5$ to $6.0 \mathrm{~km} / \mathrm{s}$ between 340 and $370 \mathrm{mbsf}$. These changes combine to produce an impedance contrast (Fig. F25), and this can be related to the seismic reflection data. Electrical resistivity measured by the Dual Laterolog shows a marked decrease in the $280-340$ mbsf interval and then increases significantly below 350 mbsf in the underlying gabbroic interval (Fig. F33). Overall alteration in the serpentinized, olivinerich interval is greater than in the overlying section (average $=50 \%-75 \%$ ), and it drops steadily to $20 \%-$ $40 \%$ by 400 mbsf. Higher velocity and density values correspond to the underlying gabbroic interval.

A second strong gradient in borehole electrical resistivity is present from 730 to 760 mbsf. Core sample porosity drops from an average of 1.5\% (400-700 mbsf) to $1 \%$ (700-800 mbsf) and maintains an average of $0.6 \%$ at greater depths. These physical property changes approximately coincide with a rapid drop in overall level of alteration (Fig. F17, F34) across this interval. Intriguingly, below $~ 925 \mathrm{mbsf}$, average sample velocities steadily decrease from $\sim 5.9$ to $\sim 5.5 \mathrm{~km} / \mathrm{s}$ at $1415 \mathrm{mbsf}$, whereas the densities remain stable on average (Fig. F33). The cause of this decrease in compressional velocity is not clear but could be related to microcracking due to unloading during the coring process at these depths.

The check shot experiment extended from 275 to 840 mbsf with average station spacing $\sim 50 \mathrm{~m}$. Tool failure and high seas combined to preclude collection of any seismic measurements during the final logging run. The check shot data indicate an average velocity in the upper $550 \mathrm{~m}$ of the footwall in Hole $\mathrm{U} 1309 \mathrm{D}$ of $5.5-5.6 \mathrm{~km} / \mathrm{s}$. An increase is indicated for greater depths by higher average velocities $(5.8 \mathrm{~km} / \mathrm{s}$ for stations 580-796 mbsf). Interval velocities computed from the automatic picks on stacked seismograms vary between stations. At this stage, we cannot rule out the determination of a velocity of $>7$ $\mathrm{km} / \mathrm{s}$ between 580 and $635 \mathrm{mbsf}$. Adjustments that could compensate for an error in seismometer position(s) of several meters do not change the basic result of a thin higher-than-average velocity interval. It is possible that a lens of essentially unaltered, olivine-rich rock occurs within the Fresnel zone of the check shot experiment at Hole U1309D (on the order of a few hundred meters), although confidence in this result will require additional seismic measurements. 
Temperature in the borehole increases with depth as expected (Fig. F35). Because of the significant impact of drilling in the hole, the measurements made provide minimum estimates of what the actual formation temperature is. The Temperature/Acceleration/ Pressure (TAP) tool recorded a temperature of $120^{\circ} \mathrm{C}$ at the bottom of the hole (1415 mbsf). The temperature is somewhat lower than predictions from a simple cooling plate model of a spreading ridge flank with an age of $\sim 2 \mathrm{Ma}$. However, the measured temperatures are a minimum (owing to hole cooling during coring), and much more careful measurement is required before quantitative interpretation should be made. These initial results suggest that thermally driven flow in the hole is likely to occur. Several drops of a few degrees were recorded in narrow intervals on repeated TAP runs (Fig. F35). At least two of these coincide with documented fault zones $(\sim 785$ and $1107 \mathrm{mbsf})$, perhaps indicating fluid flow there.

\section{Microbiology}

A total of 12 samples for microbiological investigations were collected from whole-round core samples recovered from Holes U1309B and U1309D during Expedition 304. Sample depths ranged from 0.45 to $396.5 \mathrm{mbsf}$, and all major rock types were included: carbonate sediment, basalt, diabase, gabbro, and serpentinized peridotite. Shipboard cultivation studies indicate growth of matter from two altered gabbro samples at elevated temperature, based on positive fluorescence tests. Shore-based analyses are required to confirm that this is a microbial signature as opposed to being due to inorganic material.

Additional microbiological studies were conducted on 15 whole-round core samples taken from 401 to 1391 mbsf during Expedition 305. Gabbro, olivine gabbro, and olivine-rich troctolite were sampled. In an effort to establish a culture collection of endolithic microbes, four different types of media, as well as agar plates, were inoculated with portions of these core samples. Growth was observed from two samples based on a positive fluorescence test. Again, because of the autofluorescence of rock particles, the presence of microorganisms can neither be confirmed nor denied until a shore-based molecular analysis of cultures is undertaken.

\section{Hanging wall sites}

Site U1310 was drilled to assess any petrogenetic relationship between volcanic rocks in the hanging wall and potential source rocks recovered in the footwall, to document faulting and any rotation of the hanging wall, and to compare the alteration and deformation styles between the footwall and hanging wall cores. The site was located where the hypothesized detachment that forms the corrugated central dome might be intersected once drilling reached the base of the hanging wall. The position of a seismic reflector (Canales et al., 2004) beneath Site U1310 may indicate that the detachment occurs at a depth of 250-350 mbsf. Recovery of rock from within the detachment fault zone was a high priority, inferred to be more likely where hanging wall volcanic rocks may armor the fault than at Site U1309, where seafloor exposure of the detachment is likely to have degraded (or even removed) the material because of weathering and/or erosion. In addition, the difficulty associated with the bare-rock spud makes recovery of a thin detachment zone unlikely at the footwall site.

Because of drilling difficulties at Site U1310, we developed an alternate strategy for delivering some of the objectives outlined for the hanging wall site. Site $\mathrm{U} 1311$ is on the lower eastern slope of the central dome, along seismic Line Meg-10 (Canales et al, 2004), where D-reflector is interpreted to surface before diving east beneath the hanging wall. The site can be interpreted as a possible klippe of hanging wall rock, stranded above the detachment fault. We note that if this target is not a klippe, but instead is either the detachment surface itself or postexposure volcanic deposits, objectives related to penetration into D-reflector and into the footwall would still be addressed at this site.

\section{Site U1310}

Site U1310 is located $\sim 10 \mathrm{~km}$ west of the center of the rift valley (Fig. F2). TOBI and DSL120 side-scan sonar data and bathymetry indicate that the site is on a small fault-bound horst, $\sim 600 \mathrm{~m}$ east of the break in slope inferred to mark the termination of the detachment fault exposed on the central dome. The site coincides with the eastern end of Alvin dive 3643 , cruise AT3-60, in an area with numerous small northeast-striking scarps (both southeast and northwest facing) (Fig. F36). Based on nearby Alvin observations and sampling, these scarps expose pillow basalts.

A push test at the end of the camera survey indicated there was as much as $6 \mathrm{~m}$ of unlithified microfossil ooze in Hole U1310A $\left(30^{\circ} 11.49^{\prime} \mathrm{N}, 42^{\circ} 03.93^{\prime} \mathrm{W}\right.$; $2582.8 \mathrm{mbsl})$. No coring was attempted at this site, but $\sim 1 \mathrm{~kg}$ of broken basaltic material was recovered from the hammer drill casing when it returned to the rig floor. The dominant rock type is sparsely plagioclase-phyric fine-grained pillow basalt. A single $\sim 10 \mathrm{~cm}$ pillow fragment has a palagonitized glass rim grading through a spherulitic zone to a microcrystalline interior. The remaining material ranges in size 
from $\sim 5 \mathrm{~cm}$ to dust. It includes palagonitized glass fragments, some of which are encrusted by calcareous sediment and/or iron-manganese oxides, angular and drill-rounded fine-grained basalt fragments, minor calcareous sediment, and iron manganese oxides. The finer material includes separate fragments and coatings of ferrous and siliceous welding slag derived from assembly and disassembly of the bottomhole assembly (BHA).

The first core recovered from Hole U1310B $\left(30^{\circ} 11.48^{\prime} \mathrm{N}, 42^{\circ} 03.92^{\prime} \mathrm{W} ; 2582.7 \mathrm{mbsl}\right)$ contained 1.3 $\mathrm{m}$ of fist-sized and smaller pieces of basalt from the $13.5 \mathrm{~m}$ interval below a $5 \mathrm{~m}$ thick sediment cover. Although we cored as deep as $23 \mathrm{~m}$, the second core barrel was still in the lower BHA when it severed, so no rock was recovered from below 18.5 mbsf. Most of the basalt fragments recovered from Core 304U1310B-1R are broken; alteration along these fracture surfaces is minimal and the interior is $<1 \%$ altered, suggesting the fragments are derived from in situ pillows. The piece interiors are also almost unaltered. Vesicles compose $3 \%-5 \%$ of the pieces analyzed. Vesicles close to fracture surfaces are internally discolored brown but not filled; spherulitic zones appear light brown in places, and within these zones, plagioclase appears white rather than transparent. Some fragments have a glassy rim 1-3 $\mathrm{mm}$ thick with relatively fresh glass. Thin zones of palagonite are mostly confined to the outer pillow surface. Glass samples were taken for onshore analysis (see 304GLASS.XLS in "Supplementary material").

In thin section, the pillow interiors appear fresh, with 5\%-10\% seriate plagioclase needles and radiating clusters in a glassy groundmass characterized by branching, feathery quench textures. Sparse anhedral olivine and prismatic plagioclase microphenocrysts are no more than $0.5 \mathrm{~mm}$ in size, with rare grains up to several millimeters in long dimension. Crystal clots composed of subophitic intergrowths of plagioclase and olivine are relatively common. Major and trace element geochemistry suggests that the basalt is a primitive tholeiite in composition. The basalt has $49.35 \mathrm{wt} \% \mathrm{SiO}_{2}, 10.23 \mathrm{wt} \% \mathrm{MgO}, 9.66 \mathrm{wt} \%$ $\mathrm{Fe}_{2} \mathrm{O}_{3}, 15.21 \mathrm{wt} \% \mathrm{Al}_{2} \mathrm{O}_{3}, 11.94 \mathrm{wt} \% \mathrm{CaO}, 2.02 \mathrm{wt} \%$ $\mathrm{Na}_{2} \mathrm{O}, 0.05 \mathrm{wt} \% \mathrm{~K}_{2} \mathrm{O}$, and $0.95 \mathrm{wt} \% \mathrm{TiO}_{2}$. Site $\mathrm{U} 1310$ basalt has 7.8 ppm Ba, 72 ppm Sr, 23.9 ppm Y, 48.2 ppm Zr, 234 ppm V, and 34.3 ppm Sc. Sample 304U1310B-1R-1, 16-18 cm, is characterized by high $\mathrm{Mg}$ and low trace element contents, consistent with the observation of olivine microphenocrysts noted in thin section.

\section{Site U1311}

Site U1311 is located on a small knoll near the break in slope where the corrugated dome meets the adja- cent volcanic hanging wall block (Figs. F2, F36). The hole was sited based on the possibility that the knoll represents a thin klippe of basalt above the detachment surface. Recovery of fresh glassy vesicular basalt in Hole U1311A does not provide a definitive test of this hypothesis. The eruptive basalt could have come from the inferred hanging wall, as hypothesized, or it could have been erupted onto or against the slope of the easternmost surface of the dome at any time after exposure at the seafloor.

Hole U1311A $\left(30^{\circ} 10.61^{\prime} \mathrm{N}, 42^{\circ} 04.19^{\prime} \mathrm{W} ; 2552\right.$ meters below sea level) is located on the southern slope of the knoll. A $60 \times 60 \mathrm{~m}$ survey with the vibration-isolated television camera documented a $\sim 3600 \mathrm{~m}^{2}$ area of mud- and rubble-covered seafloor, with a moderate slope to the south-southeast. Along the northeastern corner of the survey area, a moderately to steeply southeast dipping, $>20 \mathrm{~m}$ high scarp oriented east-northeast $\left(\sim 075^{\circ}\right)$ crops out and is characterized by rounded pillow structures.

One attempt to drill at this site penetrated 12 meters below seafloor, including $3.5 \mathrm{~m}$ of unconsolidated mud. Recovery from the hole produced $1.5 \mathrm{~m} \mathrm{(13 \% )}$ of fresh, vesicular, moderately plagioclase-olivine phyric basalt pillows, with sparse glass preserved. Almost all pieces are angular and have broken along fracture surfaces within pillows-few, if any, were cut by the drill. The fracture surfaces are discolored dark brown and minimally altered. These observations suggest that the core is derived from in situ pillows. Some piece interiors include multiple gray Liesegang bands, indicating pervasive minor or incipient alteration. Vesicles close to fracture surfaces are internally discolored brown but not filled.

The basalt is dark gray to black in color and characterized by abundant (5\%-10\%) seriate plagioclase that locally occurs in radiating clumps. Sparse euhedral plagioclase phenocrysts range upward in size to $\sim 2 \mathrm{~mm}$. In thin sections taken from pillow interiors, the basalt appears fresh, with minimal darkening of the matrix and local orange to green smectites either in vesicles or in the vicinity of olivine. Randomly oriented acicular to prismatic plagioclase, ranging in size from $<0.1$ to $0.5 \mathrm{~mm}$, makes up $\sim 40 \%$ of the sample (Fig. F37). Many of the plagioclase crystals have a hollow or swallowtail quench morphology. Olivine microphenocrysts ( $5 \%)$ appear either in subophitic crystal clots with plagioclase or as euhedral microphenocrysts ranging in size from 0.1 to 0.3 $\mathrm{mm}$ and in shape from larger prisms to smaller diamonds and more complex quenched forms. The remainder of the rock is the devitrified glass matrix, dominated by plumose quenched clinopyroxene with anhedral interstitial plagioclase. Oxide intervals are abundant, up to $2 \%$, in the matrix and are 
mostly present as complex quench morphologies, most likely ilmenite. Vesicles occupy $3 \%-5 \%$ of total volume. They are present in two forms, round $(\sim 0.1$ $\mathrm{mm})$ and elongate, and are irregular and locally interconnected. Most are unfilled, but a few are completely or partially filled by devitrified glass, and a few, especially near fracture surfaces, are filled by secondary green or orange smectite. They generally range in size up to $0.5 \mathrm{~mm}$ but in places are as large as $2 \mathrm{~mm}$. Where present, glass is $1-3 \mathrm{~mm}$ thick with $50 \%-100 \%$ palagonitization close to outer surfaces.

The one sample of pillow basalt (Sample 304U1311A-1R-1, 34-36 cm) analyzed for major and trace element geochemistry suggests that the basalt is a primitive tholeiite, with an Mg\# of 66. The sample is characterized by loss on ignition values of $-0.05 \mathrm{wt} \%$ and $\mathrm{H}_{2} \mathrm{O}$ and $\mathrm{CO}_{2}$ below detection limit. It has $48.97 \mathrm{wt} \% \mathrm{SiO}_{2}, 9.63 \mathrm{wt} \% \mathrm{MgO}, 9.82 \mathrm{wt} \%$ $\mathrm{Fe}_{2} \mathrm{O}_{3}, 16.81$ wt $\% \mathrm{Al}_{2} \mathrm{O}_{3}, 12.61$ wt $\% \mathrm{CaO}, 2.17$ wt $\%$ $\mathrm{Na}_{2} \mathrm{O}, 0.04$ wt $\% \mathrm{~K}_{2} \mathrm{O}$, and $1.12 \mathrm{wt} \% \mathrm{TiO}_{2}$. It has 8.8 ppm Ba, 83 ppm Sr, 26 ppm Y, 57 ppm Zr, and 38 ppm Sc, virtually equivalent to the basalt sampled in Hole U1310B. Basalt from both hanging wall sites reflect a depleted source.

\section{Discussion}

Site U1309 is located at the surface of a low-angle detachment fault exposed at the seafloor on Atlantis Massif. Holes U1309B and U1309D are at the base of a north-facing, $\sim 12^{\circ}$ slope running down from the Southern Ridge to the central dome, and the drilling took place close to the point of inflection (in the spreading-parallel direction) of the domal fault surface. The breakaway of the fault is inferred to be $\sim 5$ $\mathrm{km}$ to the west, and the fault termination (where the exposed fault intersects the seafloor) $\sim 5 \mathrm{~km}$ to the east. The dip angle of the fault at its termination is $\sim 11^{\circ}$; this value provides a minimum estimate for footwall rotation at Site U1309 because the fault is approximately horizontal at this location. Shipboard paleomagnetic data show that from 0 to 180 mbsf in Hole U1309D the remanent vector inclination is not distinguishable from the expected dipole inclination at this site. Mean inclinations from the paleomagnetically defined groups (II-V) deeper than $180 \mathrm{mbsf}$ differ from the local geocentric dipole inclination and require at least moderate and variable rotation between the different blocks. Interpretations of the amount of tectonic rotation of the recovered sequence are speculative at this stage, but it is clear that steady rotation of a single, ductilely deforming footwall block cannot explain the structural and paleomagnetic data.
The gabbroic section recovered from Site U1309 shows a lack of extensive amphibolite-facies alteration and deformation. A similar relationship is noted in shallow-penetration cores collected from the corrugated dome at $15^{\circ} 45^{\prime} \mathrm{N}$ on the MAR (MacLeod et al., 2002; Escartin et al., 2003) and contrasts markedly with the gabbroic section recovered from Hole 735B at the Southwest Indian Ridge (Robinson, Von Herzen, et al., 1989; Dick, Natland, Miller, et al., 1999; Dick et al., 2000). The overall low intensity of deformation at Site U1309 suggests that structures associated with significant slip on the detachment fault were either localized within the unrecovered upper $20 \mathrm{~m}$ or occurred at low temperature within the brittle regime and are distributed along faults documented within the upper $\sim 250 \mathrm{~m}$ of the footwall.

The relatively little-deformed nature of the plutonic section recovered from Site U1309 allows an unprecedented opportunity to study emplacement processes associated with formation of oceanic lithosphere. Intrusive contacts are preserved in many places, and their dip may suggest the type of injection (sill versus dike, for example). The observations of gabbro dikes and late magmatic leucocratic veins that crosscut more primitive rock types indicate that melt migration was controlled by brittle mechanisms during the later stages of the fractionation and crystallization process. The observation of crystal-plastic shear zones within narrow intrusions/dikes and at the contacts between gabbroic intervals suggests that the presence of melt promoted strain localization at/ near the ridge axis.

The gabbroic rocks sampled from Site U1309 are among the most primitive known along the entire MAR. The most olivine-rich end-member consists of a series of moderately serpentinized, olivine-rich troctolite intervals, locally fresh, that may represent primitive cumulates. Oxide gabbros, a rock type commonly recovered from slow-spreading midocean ridges (Robinson, Von Herzen, et al., 1989; Dick, Natland, Miller, et al., 1999; Pettigrew, Casey, Miller, et al., 1999; Kelemen, Kikawa, Miller, et al., 2004) are also present at Site U1309. Mylonitic shear zones can overprint these oxide-bearing intervals. However, the latter are most common in Hole U1309D in undeformed rocks with magmatic textures and either sharp or diffuse boundaries. The interplay between relatively late Fe-Ti oxide crystallization and deformation is probably complex, and their relative timing may be variable.

There is little magmatic deformation associated with the intrusive igneous history. This observation suggests that plutons were possibly "shielded" from deformation related to emplacement within the man- 
tle lithosphere. Alternatively, the lack of significant magmatic deformation may simply reflect differences in the timing of deformation and plutonism at the ridge axis. The drilled gabbro section is relatively continuous and structurally homogeneous, except for zones of increased crystal-plastic and brittle deformation in the upper $\sim 320$ mbsf and between 650 and 800 mbsf. Following granulite-grade shearing, there is relatively little evidence for deformation at amphibolite facies. Evidence for deformation related to denudation in the shallow part of Holes U1309B and U1309D suggests that faulting initiated at greenschist-grade conditions. These observations suggest that the footwall cooled considerably between pluton emplacement and denudation at the seafloor.

The most significant boundary within the recovered gabbroic sequence appears to be located at $\sim 600-800$ mbsf, as indicated by a series of observations, including a marked change in Mg\# at 600 mbsf (Fig. F15), a series of faults with cataclasite between $\sim 685$ and 785 mbsf (Fig. F29), changes in paleomagnetic inclination, and a change in the late metamorphic overprint below $~ 800$ mbsf (Figs. F17, F34).

The regional seismic reflector $\mathrm{D}$ was interpreted by Canales et al. (2004) to correspond to an alteration front in mantle peridotite or to a deeper detachment fault within a system of normal faults that controlled the evolution of the OCC. At the drill site, D-reflector could correspond to a strong reflector at $\sim 0.12 \mathrm{~s}$ (two-way travel time [TWT]) or to a reflector near 0.25 s TWT (see Figs. F2, F25). However, neither of these reflectors corresponds to an alteration front in mantle peridotite or a clearly defined deeper detachment fault in the recovered core. Complexity along the strike of MCS Line Meg-4 makes it difficult to be certain; the stacked section (not shown) suggests that $0.12 \mathrm{~s}$ marks D-reflector, but the migrated section (Fig. F3) suggests that it occurs at $0.25 \mathrm{~s}$ near Hole U1309D.

Onboard synthetic seismogram modeling (Fig. F25) indicates that physical property changes across the 300-400 mbsf interval could give rise to D-reflector. If $\sim 340$ mbsf coincides with D-reflector $(\sim 0.12 \mathrm{~s}$ TWT), the average velocity of the overlying section would be $\sim 5.44 \mathrm{~km} / \mathrm{s}$ locally, slightly lower than the $5.54 \mathrm{~km} / \mathrm{s}$ value determined by a check shot to 345 mbsf. Both of these values are higher than the 5.0 $\mathrm{km} / \mathrm{s}$ noted by Canales et al. (2004) for the interval velocity above this reflector in the center of MCS Line Meg-10. In Hole U1309D, it is probably the change from less altered gabbro to more altered olivine-rich rocks that dominates the local acoustic impedance contrast. Given the lithologic (and related alteration) variability with depth in Hole U1309D, it would be surprising if the $\sim 300-400$ mbsf interfaces between gabbroic rocks and olivine-rich troctolite extend at a similar depth across the central dome of Atlantis Massif. The increase in alteration in the interval 280-340 mbsf and the fact that it is embedded within a much larger gabbroic sequence contrast sharply with the interpretation (Canales et al., 2004) of D-reflector as the base of a regional alteration front.

If, on the other hand, D-reflector in Hole U1309D coincides with the $\sim 0.25 \mathrm{~s}$ TWT reflector, the changes in physical properties (drop in porosity, jump in resistivity, and drop in alteration; see "Geophysical measurements") across the 700-800 mbsf interval might explain the impedance contrast on a seismic wavelength. However, we do not have sonic log data to confirm in situ velocities below 750 mbsf. Tying D-reflector to this deeper set of physical property/alteration changes could support Canales et al.'s (2004) inference of a subsurface fault giving rise to D-reflector. Fault gouge recovered near $750 \mathrm{mbsf}$ confirms the existence of at least a narrow fault zone; low recovery over a broader interval (10-20 m) may indicate a greater width. The dip in borehole temperature at this depth suggests the fault zone could be permeable enough to allow fluid flow, and such localized change in properties would certainly contribute to an observable impedance contrast.

Our findings at Site U1309 are in marked contrast with the expectation that we would drill through an alteration front in mantle peridotite at Atlantis Massif. The results are inconsistent with the predrilling hypothesis that the footwall was composed mainly of an uplifted mantle section where serpentinization was responsible for lower densities and high seismic velocity gradients in the upper few hundred meters of the footwall. A more complex model than was put forward before Expeditions 304 and 305 will be required. The fact that we did not reach fresh mantle peridotite, together with the known exposures of serpentinized mantle along the southern face of the massif, supports models of significant lateral heterogeneity in slow-spreading oceanic crust. The drilling results indicate that more detailed analysis of the existing geophysical data is warranted, using more intensive processing methods and testing a suite of possible three-dimensional subsurface models. Together with the core and logging data from Hole U1309D, this work will provide an unprecedented opportunity to advance understanding of lower crustal accretion and tectonic evolution at slowspreading ridges. 


\section{Operations summary}

\section{Expedition 304 port call}

The Ponta Delgada, Azores Islands (Portugal), port call was completed in 3.5 days. Pacing items for the port call were loading of specialty hardware required for the advanced diamond core barrel system and the HRRS, delayed incoming airfreight, and maintenance on the active heave compensator (AHC).

\section{Expedition 304 transit to Site U1309}

The last line away from Berth 12, Ponta Delgada, was at $2012 \mathrm{~h}$ on Saturday, 20 November 2004. The transit was uneventful, with the ship averaging $11.1 \mathrm{kt}$ over the $939 \mathrm{nmi}$ distance. The vessel arrived at location (based on Global Positioning System [GPS] coordinates) and launched a beacon at $0830 \mathrm{~h}$ on 24 November.

\section{Holes U1309A-U1309D}

After arriving at Site U1309, we assembled the BHA and ran the pipe to just above the seafloor. Operations began with a vibration-isolated television (VIT) camera bottom survey to determine suitable locations to spud the pilot hole and to install the HRRS. The survey was completed in $<2 \mathrm{~h}$, and an appropriate area was selected for drilling (devoid of large boulders or rubble). A water sample and temperature measurement were collected with the Water Sampling Temperature Probe (WSTP) from just above the mudline. The first hole (Hole U1309A) was a punch core with the RCB assembly to capture the surface sediments. Rotary coring commenced in Hole U1309B (without moving ship location) at $0050 \mathrm{~h}$ on 25 November 2004. Weight on bit started at 4000 $\mathrm{lb}$ with a rotation of $30 \mathrm{rpm}$ and was gradually increased to $12,000 \mathrm{lb}$ at $55 \mathrm{rpm}$ as the BHA drilled into the hard formation. Penetration rates started at $<1 \mathrm{~m} / \mathrm{h}$ but increased to $>2 \mathrm{~m} / \mathrm{h}$ with the increased weight on bit and increased rotation. A brief test of the AHC system was conducted at the start of coring operations, but the vessel heave $(4-5 \mathrm{~m})$ proved too large for the AHC. Previous experience limits the use of the AHC to $2.5 \mathrm{~m}$ maximum heave.

Coring continued to 101.8 mbsf (Table T1), when penetration ceased, likely owing to bit failure after $>86$ rotating hours. The mechanical bit release was activated, and the bit was released at the bottom of the hole. The annulus was displaced with drill (fresh) water for logging, and the pipe was pulled back to 25 mbsf. Three logging runs were completed, including the triple combination (triple combo) and Formation MicroScanner (FMS)-sonic tool strings and a test of the logging heave compensation winch. Logging was completed and operations in Hole U1309B ended at $0805 \mathrm{~h}$ on 1 December.

The HRRS was run in an attempt to install $31.5 \mathrm{~m}$ of casing in Hole U1309C, 20 m west of Hole U1309B. The hammer-in casing attempt started at $0945 \mathrm{~h}$ on 2 December. After $\sim 5-6 \mathrm{~m}$ penetration, high torque and loss of pipe rotation dictated an inspection with the subsea camera. This inspection revealed that the casing running tool had prematurely released, disconnecting the BHA with the hammer from the casing string. With no further advancement possible, Hole U1309C was abandoned. A 25 m length of 133/ 8 inch casing was left sticking out of the seabed at Hole U1309C. A new drilling target (Hole U1309D) was selected, the HRRS system was prepared, and the vessel was offset $20 \mathrm{~m}$ north of Hole U1309B. Hole U1309D was spudded at $0120 \mathrm{~h}$ on 4 December. The HRRS was drilled to $20.5 \mathrm{mbsf}$, leaving $4.5 \mathrm{~m}$ of casing above the seafloor. After running the reentry cone, the VIT camera was deployed to inspect the HRRS. All components appeared to be in place. The BHA was pulled clear and tripped back to surface. An RCB BHA was then assembled to reenter Hole U1309D to core ahead from 20.5 mbsf.

The first reentry into Hole U1309D was accomplished in $10 \mathrm{~min}$ by $0240 \mathrm{~h}$ on 6 December. Cores 304-U1309D-1R through 22R (20.5-131.0 mbsf; recovery $=51 \%$ ) were predominantly $4.5 \mathrm{~m}$ penetrations, but two $\sim 9.5 \mathrm{~m}$ cores (Cores 16R and 17R; 89.0-107.9 mbsf) were cut to compare recovery rates. Penetration rates and operating parameters were similar to pilot Hole U1309B. Coring was terminated at 60.75 bit rotating hours to prevent bit deterioration from affecting hole conditions. After the bit cleared the top of the reentry cone at Hole U1309D, the vessel was moved to Site U1310 using the dynamic positioning (DP) system.

\section{Site U1310}

During the DP transit to Site U1310, drill pipe was added to reach the estimated $2580 \mathrm{~m}$ of water depth. A subsea camera survey located a target for Hole U1310A, and after a punch test to determine sediment thickness, the pipe was recovered. The bit cleared the rotary table at $1520 \mathrm{~h}$ on 10 December 2004, officially ending Hole U1309D and starting Hole U1310A. The bit was in poor condition, with numerous missing and broken teeth and three loose cones.

The HRRS was assembled and tested at the rig floor prior to deployment. During the initial assembly, an error was discovered in the length measurement of the new nonagon design bit. This resulted in the overall casing length being too short for the BHA. The bottom joint of casing had to be removed, and 
the ring bit had to be removed from the casing and reinstalled on a longer joint of casing. The completed assembly was then deployed to the seabed and a drill pipe measurement to the seafloor was recorded at 2594 meters below rig floor. The HRRS was spudded at $0000 \mathrm{~h}$ on 12 December. Hammer drilling continued for the next $6.75 \mathrm{~h}$ with little penetration. The HRRS was pulled back to the surface, and it was clear that the nonagon design bit had failed. The drive bit had pushed through the ring bit and could not have been engaging during hammer operation. The nonagon pilot bit and nonagon ring bit were changed to a wing bit with an open casing shoe.

After $6 \mathrm{~h}$ during this HRRS installation attempt, penetration stopped and we were unable to maintain rotation. We pulled the hammer assembly from the seafloor, moved $10 \mathrm{~m}$ north, and attempted a third penetration. After $5 \mathrm{~h}$, penetration stopped again with $\sim 6 \mathrm{~m}$ of hole, so we pulled and inspected the hammer system. The bit was missing gauge buttons from the outside of the wings. The casing was shortened to a single joint, and a new wing-style reamer bit was installed. We elected to reenter the short hole started with our previous installation attempt to reduce the required depth of penetration. After a total of $\sim 13 \mathrm{~m}$ of penetration, the penetration rate was so slow we decided to release the casing and continue with the reentry funnel deployment. However, we could not extract the pilot bit from the hole even after multiple attempts. After a several-hour struggle, we were finally able to extract the assembly, casing in tow, from the seabed. When brought to the rig floor, we determined the running tool had released the casing but the wing-style reamer bit was lodged in the lower end of the casing, preventing extraction of the bit. One reamer arm was missing and the lower part of the casing was bent. Because no installation was successful but basalt pieces were recovered from behind the arms of the hammer and within the casing, we elected to call all the attempts collectively Hole U1310A and curated the material recovered as Core 304-U1310A-1M (miscellaneous).

For fear that the missing reamer arm lay at the bottom of Hole U1310A, the vessel was offset $10 \mathrm{~m}$ to the east and an RCB coring assembly was deployed to initiate a bare rock penetration in Hole U1310B. Hole U1310B was spudded at $2250 \mathrm{~h}$ on 15 December. The first coring interval (Core 304-U1310B-1R; $0-18.5$ mbsf; recovery $=7 \%$ ) required $30 \mathrm{~h}$ to complete. High torque and rubble falling into the hole were relentless during the coring operation. After recovering Core 304-U1310B-1R, $3 \mathrm{~m}$ of fill had to be cleared from the hole before continuing coring. Cutting Core 304-U1310B-2R required an additional $16.5 \mathrm{~h}$. When the wireline failed to retrieve the core barrel (after two attempts), the operations team surmised we had lost the lower part of the BHA. Recovery of the pipe proved this to be the case and ended operations at Site U1310.

\section{Site U1311}

$\mathrm{A}<1 \mathrm{nmi}$ transit brought us to our alternate hanging wall drilling location. After a brief subsea camera survey, Hole U1311A was spudded with an RCB assembly at $2040 \mathrm{~h}$ on 18 December 2004. Core 304U1311A-1R (0-12 mbsf) required $>26 \mathrm{~h}$ to cut. After the first core had been cut in Hole U1311A, there was at least $3 \mathrm{~m}$ of fill in the $12 \mathrm{~m}$ deep hole. We attempted to clear the hole for several hours without success, and the hole was abandoned. Based on our prespud bottom survey, we elected to move $\sim 100 \mathrm{~m}$ north, survey another location, and attempt another hole at this site.

Because we had not been able to keep a hole clear of fill at Site U1310 or in Hole U1311A, we decided to attempt to drill a large-diameter bore without coring. We hoped this strategy would allow deployment of a casing to isolate the upper part of the formation and allow deeper penetration. The two options left in our arsenal of drilling tools were a large rotary bit and the wing-style, reaming hammer bit. We surmised that the rotary bit was not likely to be successful, based on our attempts with rotary coring bits. The larger bit face would translate to less weight on bit per unit area, thus yielding even slower penetration rates. In addition, the size difference between the top of the bit and the BHA would provide ample space for rocks falling into the hole to trap the bit. After a brief subsea camera survey, we chose a location with a smooth sediment cover to deploy the hammer bit. Although there was an initial rapid penetration rate, at a depth of only a few meters below seafloor penetration virtually ceased. High torque stalled rotation, and picking the bit up off bottom to regain rotation allowed rock to cascade into the hole underneath the bit. We hammered for $\sim 19 \mathrm{~h}$, but could gain no headway, so operations at Site U1311 were terminated.

\section{Deepening and logging Run 1: Hole U1309D, Holes U1309E-U1390H}

Following a pipe trip to install an RCB BHA, we reentered Hole U1309D through the HRRS and recommenced coring at 131 mbsf. Cores 304-U1309D-23R through 47R (131.0-252.4 mbsf) were cut with an average recovery of $64 \%$. We made a pipe trip to pick up a fresh bit, and coring continued through Core 304-U1309D-78R with 74\% recovery (average recovery for Hole $1309 \mathrm{D}=58 \%$ ). We terminated coring at 
401.3 mbsf after the RCB bit had accumulated 56 rotating hours. The hole was cleaned and filled with freshwater in preparation for logging. A shallow-penetration hole (Hole U1309E) was cored to $3.8 \mathrm{mbsf}$ $10 \mathrm{~m}$ east of Hole U1309D (Core 304-U1309E-1R). Continuing with efforts to capture the oldest sediments draping the central dome of Atlantis Massif, as well as the detachment surface, we moved the vessel in DP mode to a site $275 \mathrm{~m}$ northwest of Hole U1309D. Hole U1309F was initiated with the RCB and cored to 4.8 mbsf (Core 304-U1309F-1R). Because RCB coring was not successful in recovering the uppermost basement in either Hole U1309E or U1309F, we tripped the pipe in preparation for logging.

We reentered Hole U1309D with a new APC/XCB bit, and our intention was to log the hole then attempt shallow cores with the XCB. The bit was positioned in the casing, but the logging tools were unable to pass an obstruction at $\sim 40$ mbsf. Because the $\mathrm{XCB}$ bit would not fit in the RCB hole, we terminated the logging attempt and pursued shallow-penetration coring. We made a transit in DP mode to an alternate location on the dome, where a submersible dive had observed a hard carbonate cap (interpreted to represent the oldest sediment cover on the dome) directly overlying basement. Core 304-U1309G-1X was cored to $3.5 \mathrm{mbsf}$, but no hard carbonate or recognizable fault rock was recovered. We elected to make a final attempt to recover the lithified carbonate and upper basement with the APC. Only the upper half of the APC barrel returned. Subsequently, we chose to trip the pipe to install a logging bit to guide the pipe past the obstruction in Hole U1309D and accomplish our logging objectives in that hole. Triple-combo and FMS-sonic tool string runs were successful, but an Ultrasonic Borehole Imager run was not attempted since the second FMS pass ended with fallen rock briefly trapping the tool in the hole. The tool was extracted with no significant damage.

After logging operations were concluded, there was sufficient time left in the expedition for a short bit run. We elected to attempt a single short RCB core at the same location as Hole U1309G. Using the retired bit from our last coring run, we attempted coring to a depth of just $>2 \mathrm{~m}$ below the soft sediment blanket, but the core barrel returned empty. With $\sim 5 \mathrm{~h}$ of operations time left in the expedition, the bit was returned to the seafloor and Core $304-\mathrm{U} 1309 \mathrm{H}-1 \mathrm{R}$ was cut without circulation in the upper $0.5 \mathrm{~m}$ and low pump pressure for the remainder of coring $(\sim 3.5 \mathrm{~m})$. The pipe was pulled and inspected, and we were under way for Ponta Delgada by 0700 h on 4 January 2005.

\section{Expedition 305 Port Call}

Expedition 305 began when the first line was placed ashore at Pier 12 in Ponta Delgada on the island of Sao Miguel, Azores Islands, Portugal, at $2120 \mathrm{~h}$ on 7 January 2005. The three pacing items for the port call were an American Bureau of Shipping (ABS) Annual and Statutory survey, an overhaul of the drawworks transmission, and the replacement of the AHC hydraulic hose bundle.

The ABS survey was completed by the morning of 11 January. The replacement hose for the AHC was determined to be defective, so the AHC was not operational for Expedition 305. The completion of the drawworks transmission repair was dependent upon the arrival of hardware from the Transocean warehouse in Houston, Texas (USA). Customs clearance in Lisbon, Portugal, delayed arrival of these parts until $\sim 1530 \mathrm{~h}$ on 12 January. At $1715 \mathrm{~h}, 12$ January, the last line was released from the dock, and, after clearing the harbor entrance, the pilot was released at $1721 \mathrm{~h}$ and the vessel began the journey to Site U1309. The duration of the port call was 4.8 days.

\section{Transit to Site U1309}

The transit to Site U1309 covered $1002 \mathrm{nmi}$ at an average speed of $10.7 \mathrm{kt}$. During the transit, the ship's clocks were retarded two $h$ to $-3 \mathrm{~h}$ Universal Time Coordinated. On approach to Site U1309, we conducted a $17.8 \mathrm{nmi}$ towed magnetometer survey near the site. The survey line began at $30^{\circ} 4.7^{\prime} \mathrm{N}$, $41^{\circ} 47.0^{\prime} \mathrm{W}$, and extended west-northwest to $30^{\circ} 07.9^{\prime} \mathrm{N}$ and $42^{\circ} 07.1^{\prime} \mathrm{W}$.

\section{Site U1309}

\section{Initial deepening of Hole U1309D}

The vessel was positioned over Hole U1309D at 1600 h on 16 January 2005 using the GPS and the beacon that was deployed during Expedition 304. At $0027 \mathrm{~h}$ on 17 January, we reentered Hole U1309D and deployed the WSTP to the bottom of the hole. To minimize contamination or disturbance of the borehole water column, the drill string was lowered to $\sim 10 \mathrm{~m}$ off the bottom of the hole with minimum rotation and no circulation. After the WSTP was retrieved, 3 $\mathrm{m}$ of fill was cleaned from the bottom of the hole.

Between 17 January and 30 January, we cored from 401.3 to 837.4 mbsf (Table T1) using four C-7 rotary core bits. The average rate of penetration steadily decreased downhole from 2.6 to $1.6 \mathrm{~m} / \mathrm{h}$, averaging 2.2 $\mathrm{m} / \mathrm{h}$ for the 14 day coring operation, with recovery averaging $>80 \%$. Based on a conservative estimate of bit life, we elected to change bits after nominally 50 $h$ of rotation. At the end of each bit run, the bits re- 
turned worn but essentially undamaged. Mud sweeps $(20 \mathrm{bbl})$ were circulated every $10 \mathrm{~m}$ of advance to clean the hole. Fluorescent microspheres and perfluorocarbon tracers (PFTs) were deployed episodically during cored intervals at depths where microbiology samples were requested. However, PFT use was discontinued after Core 305-U1309D-90R at the request of the shipboard microbiologist because there was insufficient time to process samples rapidly enough. At the end of the fourth bit run, the hole was conditioned for logging, including displacing the borehole fluid with freshwater to improve the logging signal.

\section{Logging Run 1, Hole U1309D}

In preparation for logging, the bottom of the pipe was set at 170 mbsf. This allowed overlap with previous logging runs performed during Expedition 304 and positioned the pipe below an interval where minor obstructions were encountered in the borehole during reentry. Six logging runs were completed, including the triple combo, FMS-sonic, Vertical Seismic Profile (VSP), Ultrasonic Borehole Imager, and Goettingen Borehole Magnetometer tools and a test of the logging wireline heave compensation system. In accordance with IODP policy, prior to the VSP a $1 \mathrm{~h}$ visual survey of the water within a $700 \mathrm{~m}$ radius of the vessel was undertaken to ensure that no marine mammals were present. Also consonant with the policy, the generator injector gun was soft-started (gradually increased intensity for the first $30 \mathrm{~min}$ of operation) at the initiation of testing. The marine mammal watch was maintained until the VSP was secured, and no marine mammals were sighted during the experiment. Logging operations were completed at $1040 \mathrm{~h}$ on 2 February.

\section{Deepening Hole U1309D}

Between 2 February and 23 February, we cored from 837.4 to $1415.5 \mathrm{mbsf}$, using one C-7 bit and five C-9 bits. The C-9 bits are designed for harder formation coring. We elected to use C-9 bits in order to preserve the last two C-7 bits in inventory in the event we encountered softer rock or noted deteriorating performance of the C-9 bits at depth. Average rate of penetration continued at $1.6-2.4 \mathrm{~m} / \mathrm{h}$, with recovery averaging $78 \%$. We experienced no significant difference in bit performance between the styles of coring bits employed. Our routine procedure included 20bbl mud sweeps after every other cored interval to clean the hole. Coring was completed at $1015 \mathrm{~h}$ on 23 February.

During our midcruise logging run, a temperature of $\sim 60^{\circ} \mathrm{C}$ was measured by one of the magnetometer tool's sensors. We used two different approaches to verify borehole temperature prior to our final logging experiment. In our first attempt, an assortment of calibrated, heat-sensitive adhesive strips were affixed to a modified advanced piston corer (APC) brass core catcher spacer deployed in a dedicated core barrel run. The core barrel was deployed at 1162 mbsf (a few meters above the bottom of the hole at the time) and allowed to equilibrate for $17 \mathrm{~min}$ without circulation. Upon recovery, the temperature strips indicated a minimum temperature of $\sim 70^{\circ} \mathrm{C}$. During the ensuing bit trip, we deployed the WSTP to collect a water sample and temperature measurement. Before deploying the sampler, our technicians determined the thermistor on the WSTP was broken and no exact replacement was available. The shipboard electrical technician fabricated an ad hoc arrangement of the APC Temperature (APCT) tool on the WSTP and found an uncalibrated thermistor to install on the WSTP. In addition to these two temperature measuring devices, an assortment of the adhesive temperature recording strips were also affixed to the WSTP. Owing to a failed O-ring, the APCT failed to record a temperature. The thermistor on the WSTP recorded a maximum temperature of $\sim 60^{\circ} \mathrm{C}$. A subsequent bench test determined $60^{\circ} \mathrm{C}$ was the maximum recording temperature for the new WSTP thermistor/datalogger assembly. The adhesive temperature strips indicated a minimum temperature of $110^{\circ} \mathrm{C}$.

\section{Logging Run 2, Hole U1309D}

After hole conditioning on 23 February, the borehole was filled with drill water to improve the logging signal in resistive rock. A logging BHA was deployed, and the bit was set at 194 mbsf. Two passes were completed with the triple combo tool string. The second logging run utilized the FMS-sonic tool string (two passes including overlap with our midcruise logging passes); however, the sonic tool was not deployed because of tool failure. A marine mammal watch was instituted at daybreak 24 February in preparation for a VSP experiment. The three-component VSP tool failed, and, after deployment of the single-component tool, the sea state ( $>5 \mathrm{~m}$ heave) had deteriorated to the point where we were required to terminate logging. A single station was occupied and shots recorded with the single-component well-seismic tool. Operations in Hole U1309D concluded on 26 February.

\section{Final transit to Ponta Delgada}

Prior to departure from Site U1309, a towed magnetometer survey was conducted. The $950 \mathrm{nmi}$ transit required $104 \mathrm{~h}$ at an average speed of $9.1 \mathrm{kt}$. Expedition 305 concluded with the first line ashore at Ponta Delgada at 1805 h on 2 March 2005. 


\section{References}

Agar, S.M., and Lloyd, G.E., 1997. Deformation of Fe-Ti oxides in gabbroic shear zones from the MARK area. In Karson, J.A., Cannat, M., Miller, D.J., and Elthon, D. (Eds.), Proc. ODP, Sci. Results, 153: College Station, TX (Ocean Drilling Program), 123-141.

Aumento, F., Melson, W.G., et al., 1977. Init. Repts. DSDP, 37: Washington (U.S. Govt. Printing Office).

Blackman, D.K., Cann, J.R., Janssen, B., and Smith, D.K., 1998. Origin of extensional core complexes: evidence from the MAR at Atlantis fracture zone. J. Geophys. Res., 103:21315-21334. doi:10.1029/98JB01756

Blackman, D.K., Ildefonse, B., John, B.E., MacLeod, C.J., Ohara, Y., Miller, D.J., and the Expedition 304/305 Project Team, 2004. Oceanic core complex formation, Atlantis Massif-oceanic core complex formation, Atlantis Massif, Mid-Atlantic Ridge: drilling into the footwall and hanging wall of a tectonic exposure of deep, young oceanic lithosphere to study deformation, alteration, and melt generation. IODP Sci. Prosp., 304/ 305. doi:10.2204/iodp.sp.304305.2004

Blackman, D.K., Karson, J.A., Kelley, D.S., Cann, J.R., FrühGreen, G.L., Gee, J.S., Hurst, S.D., John, B.E. Morgan, J., Nooner, S.L., Ross, D.K., Schroeder, T.J., and Williams, E.A., 2004. Geology of the Atlantis Massif (MAR $\left.30^{\circ} \mathrm{N}\right)$ : implications for the evolution of an ultramafic oceanic core complex. Mar. Geophys. Res., 23:443-469. doi:10.1023/B:MARI.0000018232.14085.75

Bougault, H., Cande, S.C., et al., 1985. Init. Repts. DSDP, 82: Washington (U.S. Govt. Printing Office).

Boschi, C., Früh-Green, G.L., Delacour, A., Karson, J.A., and Kelley, D.S., 2006. Mass transfer and fluid flow during detachment faulting and development of an oceanic core complex, Atlantis Massif (MAR $30 \mathrm{~N}$ ). Geochem., Geophys., Geosyst., 7:Q01004. doi:10.1029/ 2005GC001074

Buck, W.R., 1988. Flexural rotation of normal faults. Tectonics, 7:959-973.

Buck, W.R., Lavier, L.L., and Poliakov, A.N.B., 2005. Modes of faulting at mid-ocean ridges. Nature (London, U. K.), 434:719-723. doi:10.1038/nature03358

Canales, J.P., Tucholke, B.E., and Collins, J.A., 2004. Seismic reflection imaging of an oceanic detachment fault: Atlantis megamullion (Mid-Atlantic Ridge, $30^{\circ} 10^{\prime} \mathrm{N}$ ). Earth Planet. Sci. Lett., 222:543-560. doi:10.1016/ j.epsl.2004.02.023

Cann, J., Blackman, D., Morgan, J., and MARVEL Cruise Participants, 2001. Geological inferences about the MidAtlantic Ridge $30^{\circ} \mathrm{N}$ core complex from initial analysis of side-scan, bathymetry and basalt petrography. Eos, Trans. Am. Geophys. Union, 82:F1099. (Abstract)

Cann, J.R., Blackman, D.K., Smith, D.K., McAllister, E., Janssen, B., Mello, S., Avgerinos, E., Pascoe, A.R., and Escartin, J., 1997. Corrugated slip surfaces formed at ridgetransform intersections on the Mid-Atlantic Ridge. Nature, (London, U. K.), 385:329-332. doi:10.1038/ $385329 \mathrm{a} 0$
Cannat, M., Karson, J.A., Miller, D.J., et al., 1995. Proc. ODP, Init. Repts., 153: College Station, TX (Ocean Drilling Program).

Casey, J.F., 1997. Comparison of major- and trace-element geochemistry of abyssal peridotites and mafic plutonic rocks with basalts from the MARK region of the MidAtlantic Ridge. In Karson, J.A., Cannat, M., Miller, D.J., and Elthon, D. (Eds.), Proc. ODP, Sci. Results, 153: College Station, TX (Ocean Drilling Program), 181-241.

Collins, J.A., and Detrick, R.S., 1998. Seismic structure of the Atlantis Fracture Zone megamullion, a serpentinized ultramafic massif. Eos, Trans. Am. Geophys. Union, 79(45):800. (Abstract)

Collins, J.A., Tucholke, B.E., and Canales, J.P., 2001. Structure of Mid-Atlantic Ridge megamullions from seismic refraction experiments and multichannel seismic reflection profiling. Eos, Trans. Am. Geophys. Union, 82:F1100. (Abstract)

Collins, J.A., Tucholke, B.E., and Canales, J.P., 2002. Seismic velocity structure of Mid-Atlantic Ridge core complexes. Eos, Trans. Am. Geophys. Union, 83(47):EAE03-A10390. (Abstract)

Detrick, R., Honnorez, J., Bryan, W.B., Juteau, T., et al., 1988. Proc. ODP, Init. Repts., 106/109: College Station, TX (Ocean Drilling Program).

Dick, H.J.B., Natland, J.H., Alt, J.C., Bach, W., Bideau, D., Gee, J.S., Haggas, S., Hertogen, J.G.H., Hirth, G., Holm, P.M., Ildefonse, B., Iturrino, G.J., John, B.E., Kelley, D.S., Kikawa, E., Kingdon, A., LeRoux, P.J., Maeda, J., Meyer, P.S., Miller, D.J., Naslund, H.R., Niu, Y.-L., Robinson, P.T., Snow, J., Stephen, R.A., Trimby, P.W., Worm, H.-U., and Yoshinobu, A., 2000. A long in situ section of the lower ocean crust: results of ODP Leg 176 drilling at the Southwest Indian Ridge. Earth Planet. Sci. Lett., 179:3151. doi:10.1016/S0012-821X(00)00102-3

Dick, H.J.B., Natland, J.H., Miller, D.J., et al., 1999. Proc. ODP, Init. Repts., 176 [Online]. Available from World Wide Web: http://www-odp.tamu.edu/publications/ 176_IR/176TOC.HTM.

Escartin, J., Mével, C., MacLeod, C.J., and McCaig, A., 2003. Constraints on deformation conditions and the origin of oceanic detachments, the Mid-Atlantic Ridge core complex at $15^{\circ} 45^{\prime} \mathrm{N}$. Geochem., Geophys., Geosyst., 4. doi:10.1029/2002GC000472

Früh-Green, G., Kelley, D.S., Karson, J.A., Blackman, D.K., Boschi, C., John, B.E., Schroeder, T., Ross, D.K., and MARVEL cruise participants, 2001. Hydrothermal alteration, serpentinization and carbonate precipitation at the Lost City vent field ( $30^{\circ} \mathrm{N}$ MAR). Eos, Trans. Am. Geophys. Union, 82:F1101.

Früh-Green, G.L., Kelley, D.S., Bernasconie, S.M., Karson, J.A., Ludwig, K.A., Butterfield, D.A., Boschi, C., and Proskurowksi, G., 2003. 30,000 years of hydrothermal activity at the Lost City vent field. Science, 301:495-498. doi:10.1126/science.1085582

Gillis, K., Mével, C., Allan, J., et al., 1993. Proc. ODP, Init. Repts., 147: College Station, TX (Ocean Drilling Program). 
Irvine, T.N., and Baragar, W.R.A., 1971. A guide to the chemical classification of the common volcanic rocks. Can. J. Earth Sci., 8:523-548.

John, B.E., 1987. Geometry and evolution of a mid-crustal extensional fault system: Chemehuevi Mountains, southeastern California. In Coward, M.P., Dewey, J.F., and Hancock, P.L. (Eds.), Continental Extensional Tectonics, Spec. Publ.-Geol. Soc. Am., 28:313-335.

Karson, J., Früh-Green, G.L., Kelley, D., Yoerger, D., and Jakuba, M., 2005. Detachment shear zone of the Atlantis Massif Oceanic Core Complex. Eos, Tans. Am. Geophys. Union, 86(52):T34B-03. (Abstract)

Karson, J.A., 2003. Unconformities in slow-spread oceanic crust: implications for spreading processes and dismembered ophiolites, Eos, Trans. Am. Geophys. Union, 84:F1506. (Abstract)

Kelemen, P.B., Kikawa, E., Miller, D.J., et al., 2004. Proc. ODP, Init. Repts., 209 [Online]. Available from World Wide Web: http://www-odp.tamu.edu/publications/ 209_IR/209ir.htm.

Kelley, D.S., Karson, J.A., Blackman, D.K., Früh-Green, G.L., Butterfield, D.A., Lilley, M.D., Olson, E.J., Schrenk, M.O., Roe, K.K., Lebon, G.T., and Rivizzigno, P., 2001. An off-axis hydrothermal vent field near the Mid-Atlantic Ridge at $30^{\circ} \mathrm{N}$. Nature (London, U. K.), 412(6843):145149. doi:10.1038/35084000

Kelley, D.S., Karson, J.A., Früh-Green, G.L., Yoerger, D.R., Shank, T.M., Butterfield, D.A., Hayes, J.M., Schrenk, M.O., Olson, E.J., Proskurowski, G., Jakuba, M., Bradley, A., Larson, B., Ludwig, K., Glickson, D., Buckman, K., Bradley, A.S., Brazelton, W.J., Roe, K., Elend, M.J., Delacour, A., Bernasconi, S.M., Lilley, M.D., Baross, J.A., Summons, R.E., and Sylva, S.P., 2005. A serpentinitehosted ecosystem: the Lost City hydrothermal field. Science, 307:1428-1434. doi:10.1126/science.1102556

Lavier, L., Buck, W.R., and Poliakov, A.N.B., 1999. Self-consistent rolling-hinge model for the evolution of largeoffset low-angle normal faults. Geology, 27:1127-1130. doi:10.1130/00917613(1999)027<1127:SCRHMF>2.3.CO;2

Le Maitre, R.W., Bateman, P., Dudek, A., Keller, J., Lameyre, J., Le Bas, M.J., Sabine, P.A., Schmid, R., Sorensen, H., Streckeisen, A., Woolley, A.R., and Zanettin, B., 1989. A Classification of Igneous Rocks and Glossary of Terms: Beijing (Geological Publishing House). (Trans. by Bixiang, W., Kun, S., and Lijun, B.)

Levitus, S., and Boyer, T.P., 1994. World Ocean Atlas 1994 (Vol. 4): Temperature. NOAA Atlas NESDIS 4.

MacLeod, C.J., Escartin, J., Banerji, D., Banks, G.J., Gleeson, M., Irving, D.H.B., Lilly, R.M., McCaig, A.M., Niu, Y., Allerton, S., and Smith, D.K., 2002. Direct geological evidence for oceanic detachment faulting: the MidAtlantic Ridge, $15^{\circ} 45^{\prime}$ N. Geology, 30:10:879-882. doi:10.1130/0091-7613(2002)030<0879:DGEFOD $>2$.0.CO;2

McFadden, P.L., and Reid, A.B., 1982. Analysis of paleomagnetic inclination data. Geophys. J. R. Astron. Soc., 69:307-319.

Melson, W.G., Rabinowitz, P.D., et al., 1979. Init. Repts. $D S D P$, 45: Washington (U.S. Govt. Printing Office).
Miller, M.G., 1996. Ductility in fault gouge from a normal fault system, Death Valley, California: a mechanism for strengthening and relevance to paleoseismicity. Geology, 24:603-606. doi:10.1130/0091-

7613(1996)024<0603:DIFGFA>2.3.CO;2

Nooner, S.L., Sasagawa, G.S., Blackman, D.K., and Zumberge, M.A., 2003. Constraints on crustal structure at the Mid-Atlantic Ridge from seafloor gravity measurements made at the Atlantis Massif. Geophys. Res. Lett., 30:1446. doi:10.1029/2003GL017126

O'Hanley, D.S., 1996. Serpentinites: records of tectonic and petrological history. Oxford Monogr. Geol. Geophys., Vol. 34.

Pettigrew, T.L., Casey, J.F., Miller, D.J., et al., 1999. Proc. ODP, Init. Repts., 179 [CD-ROM]. Available from: Ocean Drilling Program, Texas A\&M University, College Station, TX 77845-9547, U.S.A. [HTML]

Robinson, P.T., Von Herzen, R., et al., 1989. Proc. ODP, Init. Repts., 118: College Station, TX (Ocean Drilling Program).

Schroeder, T., and John, B.E., 2004. Strain localization on an oceanic detachment fault system, Atlantis Massif, $30^{\circ} \mathrm{N}$, Mid-Atlantic Ridge. Geochem., Geophys., Geosyst., 5. doi:10.1029/2004GC000728

Schroeder, T., John, B.E., Kelley, D., and MARVEL cruise participants, 2001. Microstructural observations of an 'oceanic core complex': Atlantis Massif, $30^{\circ} \mathrm{N}$ MidAtlantic Ridge, Eos, Trans. Am. Geophys. Union, 82:F1100.

Shipboard Scientific Party, 1999. Site 735. In Dick, H.J.B., Natland, J.H., Miller, D.J., et al., Proc. ODP, Init. Repts., 176 [Online]. Available from World Wide Web: http:// www-odp.tamu.edu/publications/176_IR/CHAP_03/ Output/chap_03.htm.

Spencer, J.E., 1985. Miocene low-angle normal faulting and dike emplacement, Homer Mountain and surrounding areas, southeastern California and southernmost Nevada. Geol. Soc. Am. Bull., 96:110-1155. doi:10.1130/0016-7606(1985)96<1140:MLNFAD $>2.0 . C O ; 2$

Tucholke, B.E., Lin, J., and Kleinrock, M.C., 1998. Megamullions and mullion structure defining oceanic metamorphic core complexes on the Mid-Atlantic Ridge. J. Geophys. Res., 103:9857-9866. doi:10.1029/98JB00167

Tucholke, B.E., Stewart, W.K., and Kleinrock, M.C., 1997. Long-term denudation of ocean crust in the central North Atlantic Ocean. Geology, 25(2):171-174. doi:10.1130/00917613(1997)025<0171:LTDOOC>2.3.CO;2

Vening Meinesz, F.A., 1950. Les graben africains resultant de compression ou de tension dans la croute terrestres? Kol. Inst. Bull., 21:539-552.

Wernicke, B.P., and Axen, G.J., 1988. On the role of isostasy in the evolution of normal fault systems. Geology, 16:848-451. doi:10.1130/00917613(1988)016<0848:OTROII >2.3.CO;2

Publication: 3 June 2006 MS 304305-101 
Figure F1. Tectonic and morphologic setting of Atlantis Massif. Bathymetric contours illustrate the deep median valley of the Mid-Atlantic Ridge and its intersection with the Atlantis transform fault. The shallow, corrugated dome composing the core of Atlantis Massif has two structural components: the central dome, where IODP footwall drilling was focused, and the Southern Ridge.

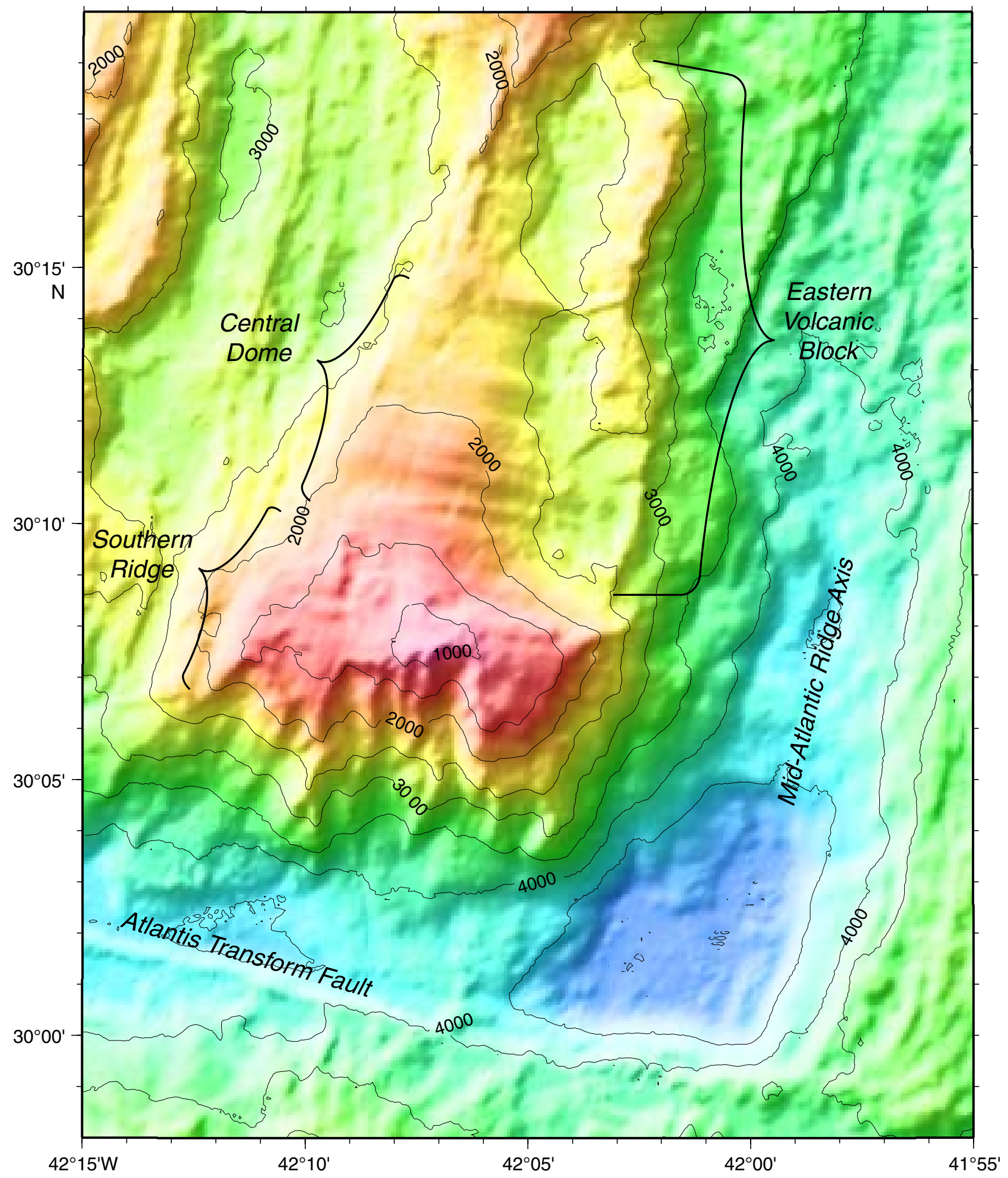


Figure F2. Base map of Atlantis Massif showing prior geological and geophysical data coverage and the location of Integrated Ocean Drilling Program (IODP) drill sites (circles). Bathymetry is contoured at $100 \mathrm{~m}$ intervals, based on a $100 \mathrm{~m}$ grid. Seismic reflection and refraction lines and seafloor mapping/sampling sites are shown. The corrugated detachment surface capping the central dome is inferred to extend beneath the eastern block, thereby making the upper crustal volcanics a hanging wall to the fault. MCS = multichannel seismic. $\mathrm{OBH}=$ ocean bottom hydrophone.

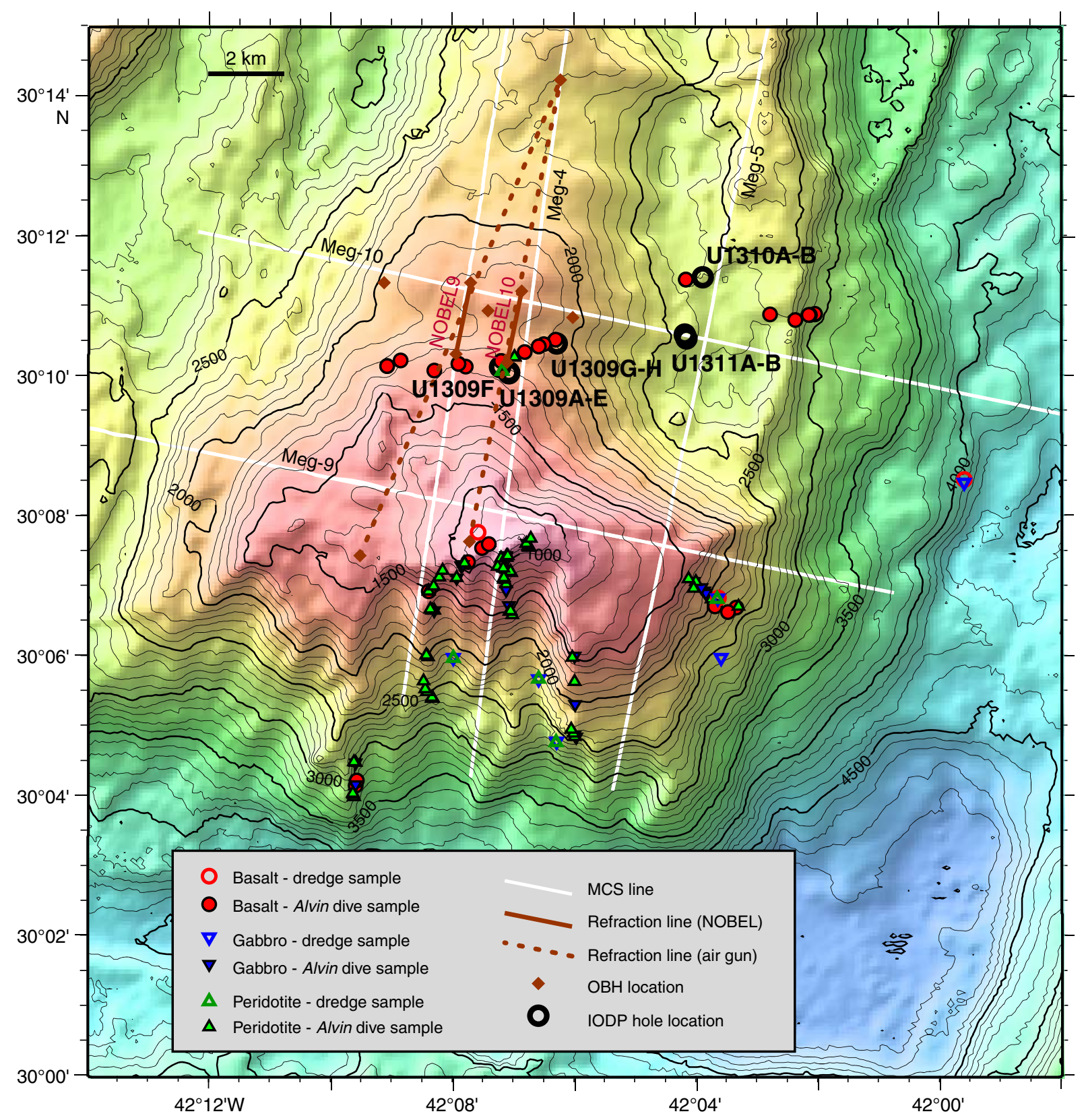


Figure F3. Seismic sections indicate subsurface structure of Atlantis Massif. A. Deep source refraction (Line NOBEL9; Fig. F2) recorded by an ocean bottom hydrophone shows arrivals indicating a high-velocity body (8 $\mathrm{km} / \mathrm{s}$, assuming plane-layered structure) at very short range. B. Velocity gradient determined from refraction analysis at Atlantis Massif (from Collins et al., 2001) is similar to that determined near ODP Site 920, where serpentinized peridotite was recovered. The gradient near Hole 735B, where only gabbro has been recovered, is not as strong. MARK = Mid-Atlantic Ridge (MAR) just south of Kane Fracture Zone, MCS = multichannel seismic, SWIR = Southwest Indian Ridge. C. A portion of MCS Line Meg-10 (Fig. F2) across the central dome. $\mathrm{CMP}=$ common midpoint. D. MCS Line Meg-4 (Fig. F2), along the strike of Atlantis Massif. MCS data were collected by the Ewing (EW-0102) in 2001 using a 10 gun array with 3100 in $^{3}(51 \mathrm{~L})$ capacity. Shot spacing was $37.5 \mathrm{~m}$. Canales et al. (2004) processed the data by CMP gathers, deconvolution, normal moveout correction, dip moveout correction, and stacking. In addition, the record section in D has been time migrated. The reflector labeled " $\mathrm{D}$ " extends below much of the domal surface.

A

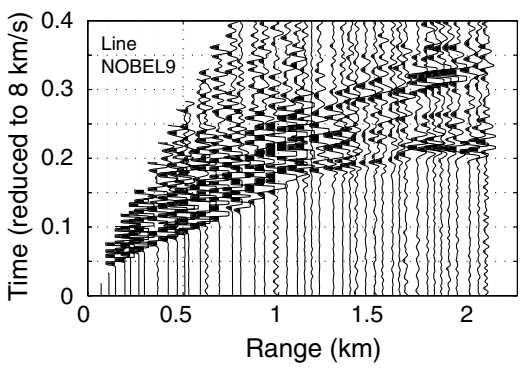

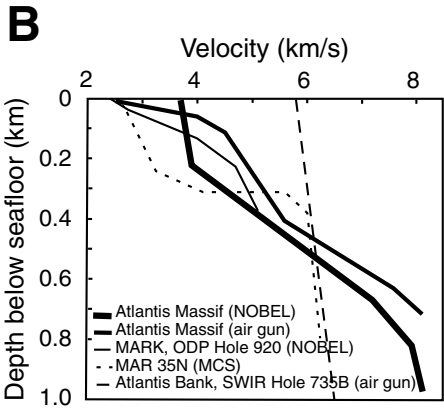

C

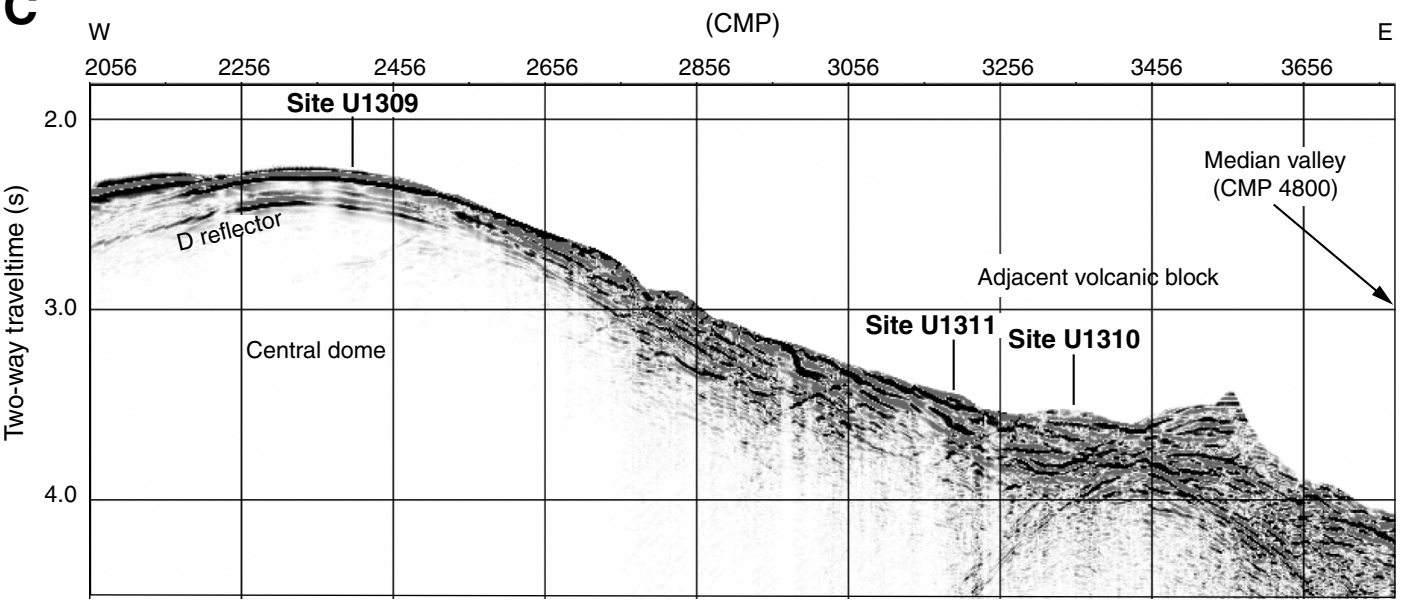

D

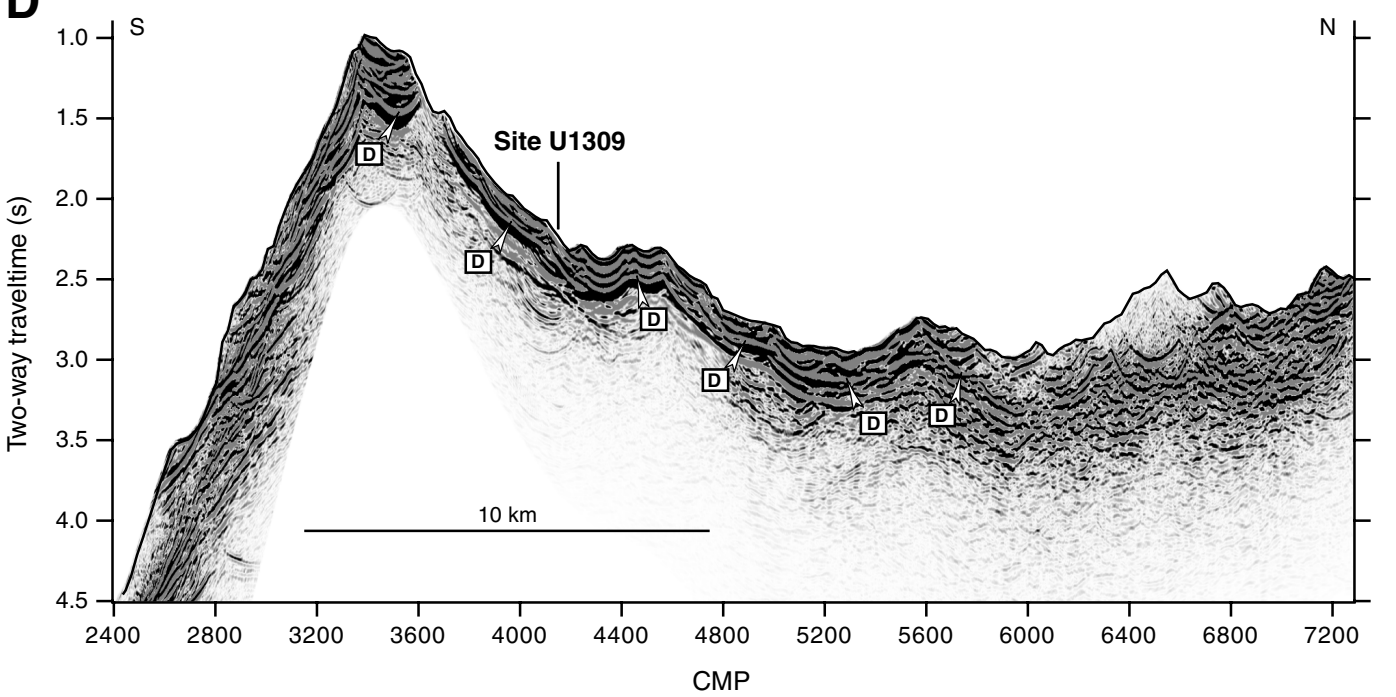


Figure F4. Bouguer gravity anomaly map of the ridge/transform intersection $\left(30^{\circ} \mathrm{N}, \mathrm{MAR}\right)$. Contribution of seafloor topography has been removed from the free-air anomaly, assuming a density contrast between seawater and ocean crust of $1700 \mathrm{~kg} / \mathrm{m}^{3}$. Trackline data from EW0102 and EW9212 have been added to the compilation presented in Blackman et al. (1998). Anomalously high densities occur within Atlantis Massif. Lower than average density (thicker crust?) characterizes the outside corner region near the fracture zone. Broader scale thermal contribution of subaxial upwelling (gravity low in northern portion of rift valley) and plate cooling have not been removed.

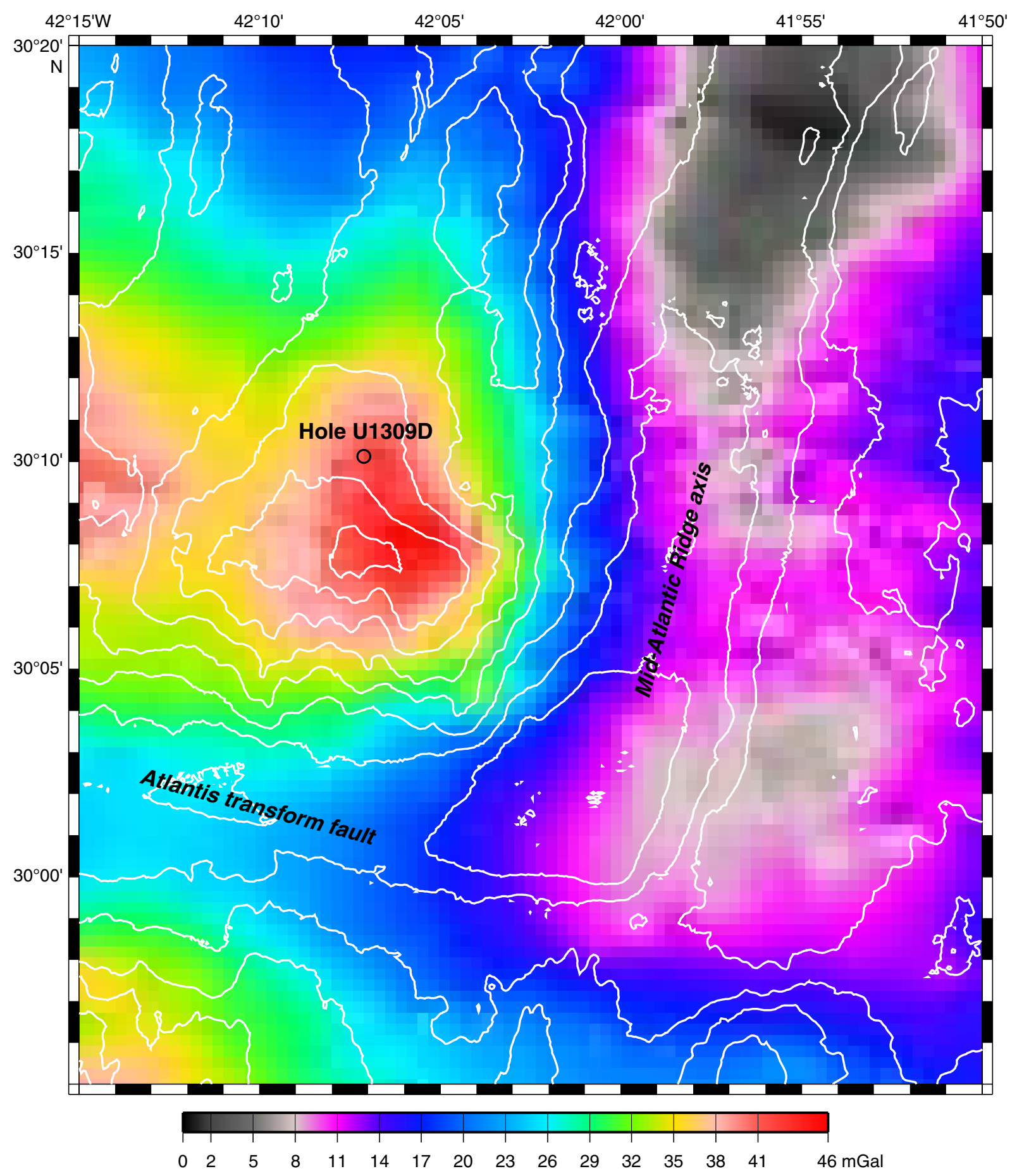


Figure F5. All holes (recovery $=>5 \%$ ) in upper mantle and lower crustal rocks drilled to date at or near midocean ridges during nine different Ocean Drilling Program (ODP) legs and Integrated Ocean Drilling Program (IODP) expeditions. Leg 147 is the only one that took place in crust created at a fast-spreading ridge. Numbers below columns are rock recoveries.

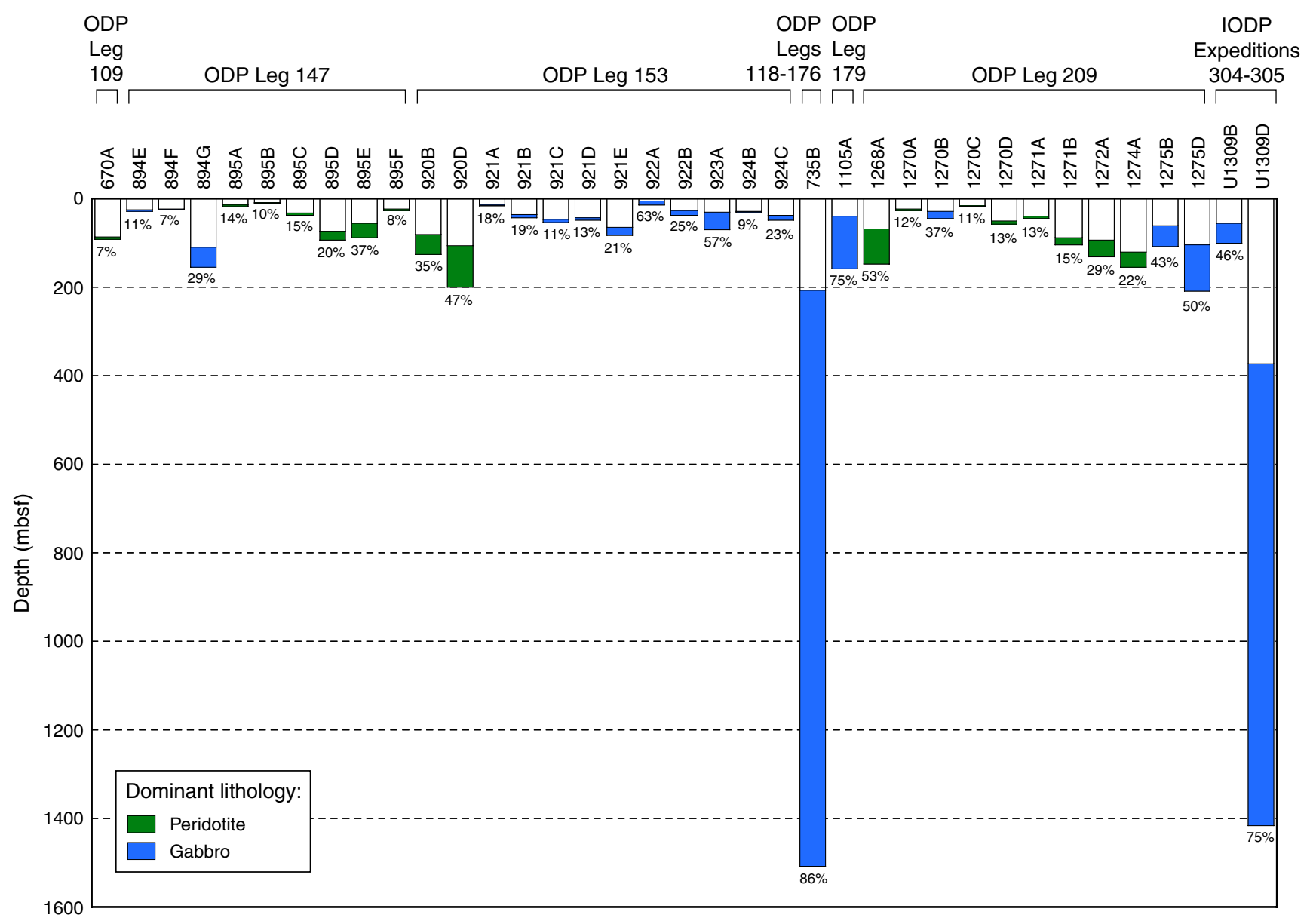


Figure F6. Rocks recovered from shallow-penetration Hole U1309H include basalt, talc-tremolite schist, and fractured diabase (Section 304-U1309H-1R-1).

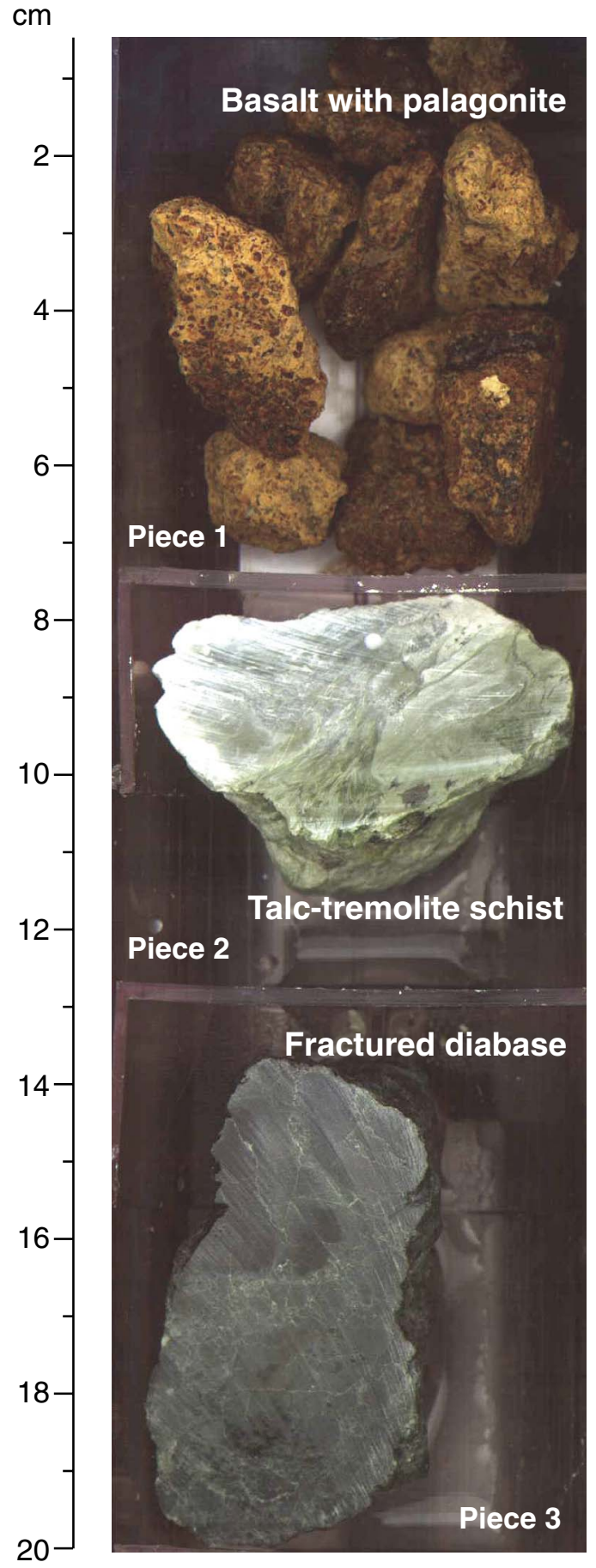


Figure F7. Lithology of core recovered from deep holes at Site U1309. A. A 20 m running average of lithologic proportions from Hole U1309D (white = no recovery). B. Lithology proportions (in percent) for Hole U1309D. (Continued on next page.)

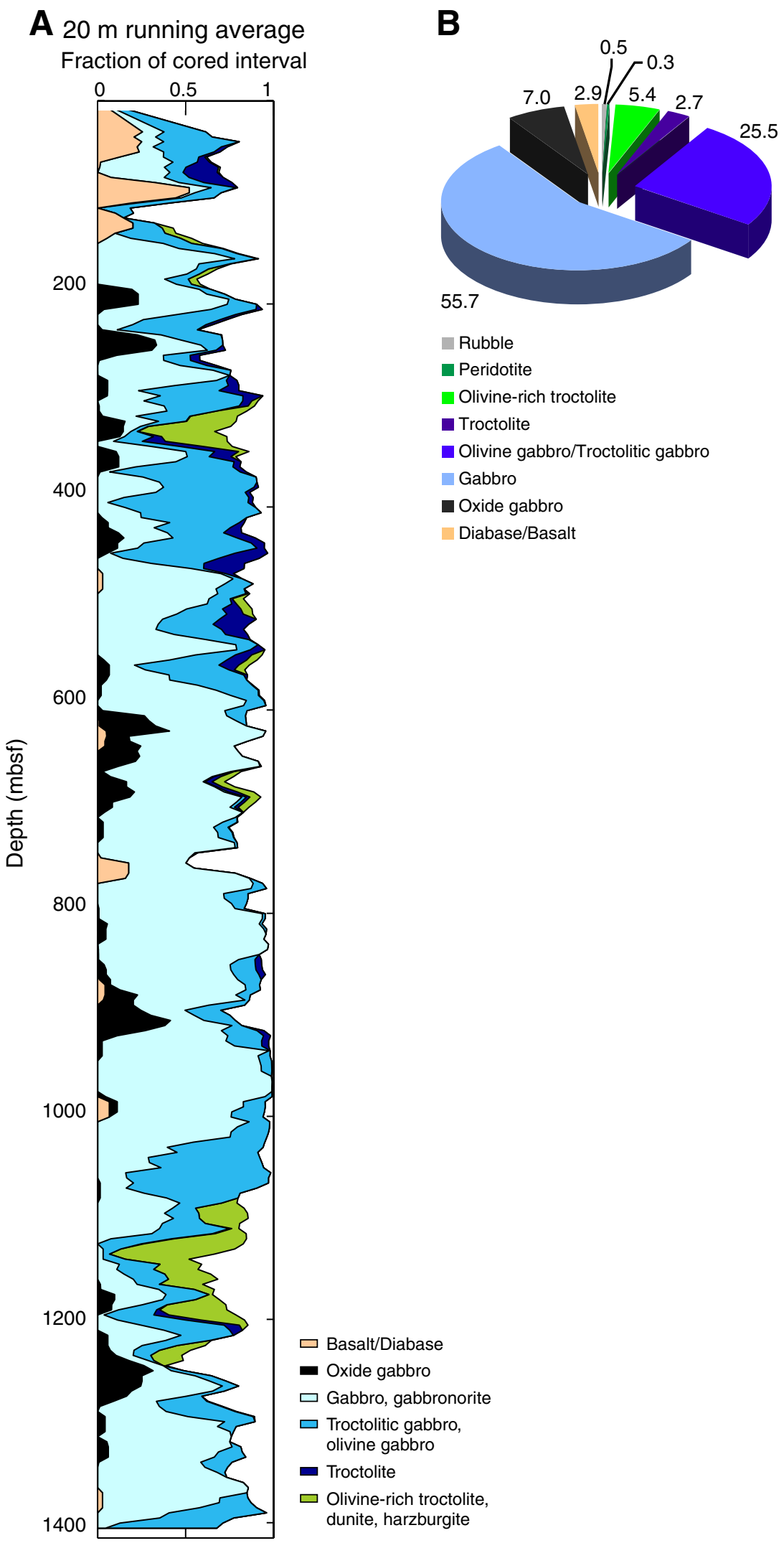


Figure F7 (continued). C. Lithostratigraphy of Hole U1309B. D. Lithostratigraphy of Hole U1309D.

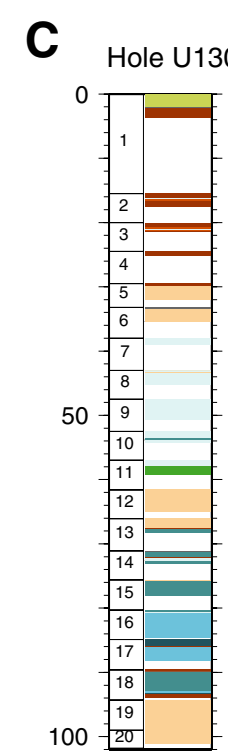

\section{Hole U1309D}

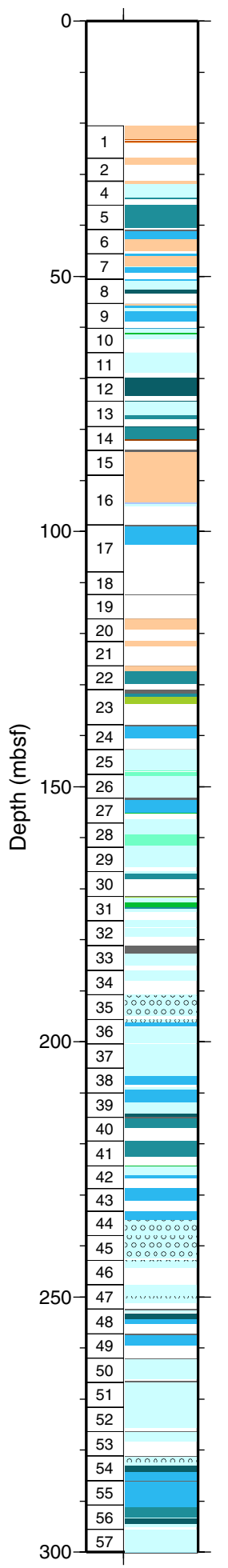

$$
300
$$$$
\begin{array}{|l|}
\hline 58 \\
\hline 59 \\
\hline 60 \\
\hline 61 \\
\hline 62 \\
\hline 63 \\
\hline 64 \\
\hline 65 \\
\hline 66 \\
\hline 07
\end{array}
$$

350
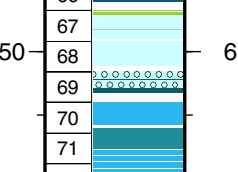

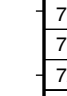

$$
\begin{array}{ll}
72 \\
73 \\
74
\end{array}
$$

\begin{tabular}{|l|l|l|l|l}
\hline 73 & \\
\hline 74 & & \\
\hline 75 & &
\end{tabular}

$$
\begin{aligned}
74 \\
75 \\
76
\end{aligned}
$$
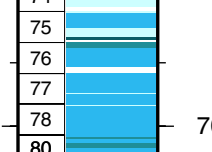

$700-$

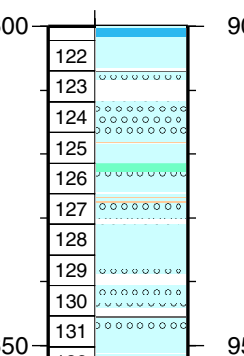

-

450

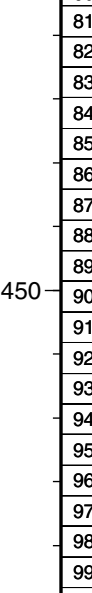

$500-$

99

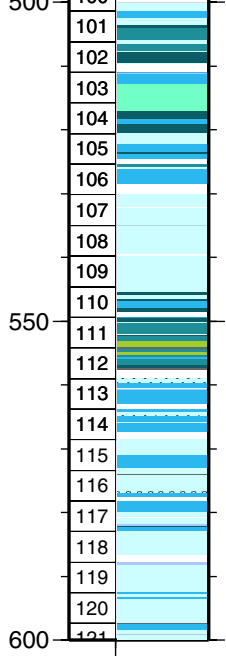

750

\begin{tabular}{|l|}
134 \\
\hline 135 \\
\hline 136
\end{tabular}

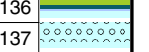

138

$139=$

140

$-$

5

$\longrightarrow$

\begin{tabular}{|l|l|}
\hline 150 \\
\hline 150 \\
\hline 150 \\
150
\end{tabular}

800

$800-\frac{163}{164} \ldots . . . .$.
900

950
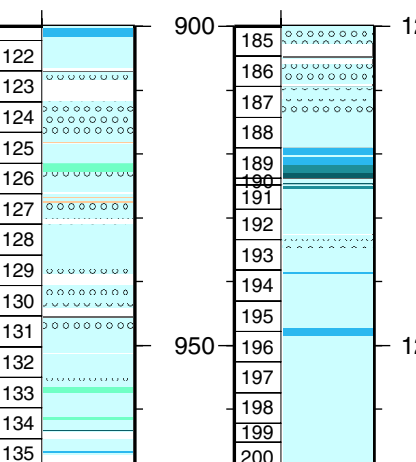

\begin{tabular}{l|l}
142 & -1000 \\
\hline
\end{tabular}

-

-

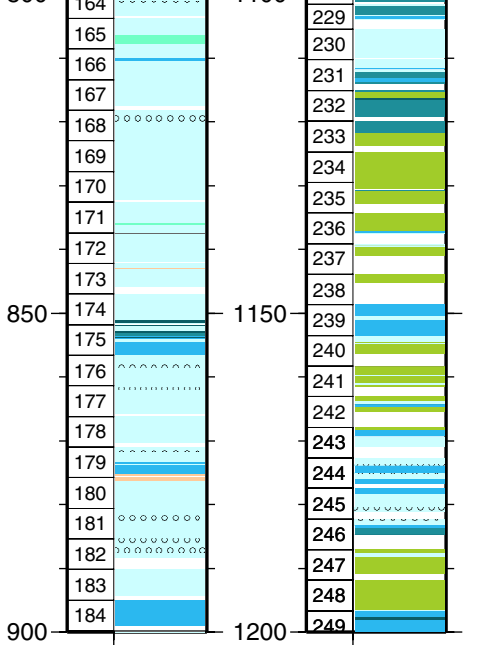

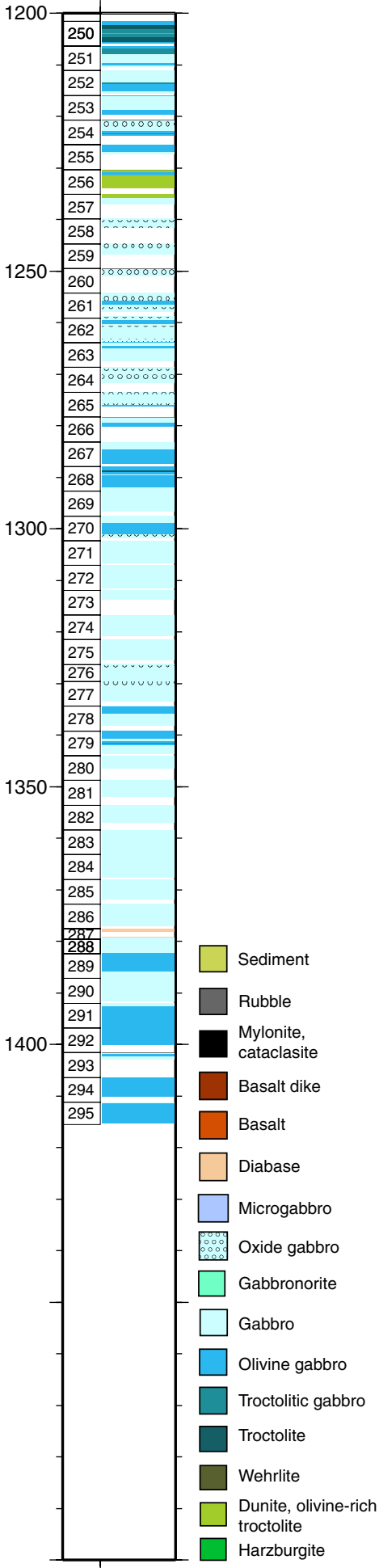


Figure F8. Contact between olivine gabbro and troctolite (interval 305-U1309D-251R-1, 44-65 cm).

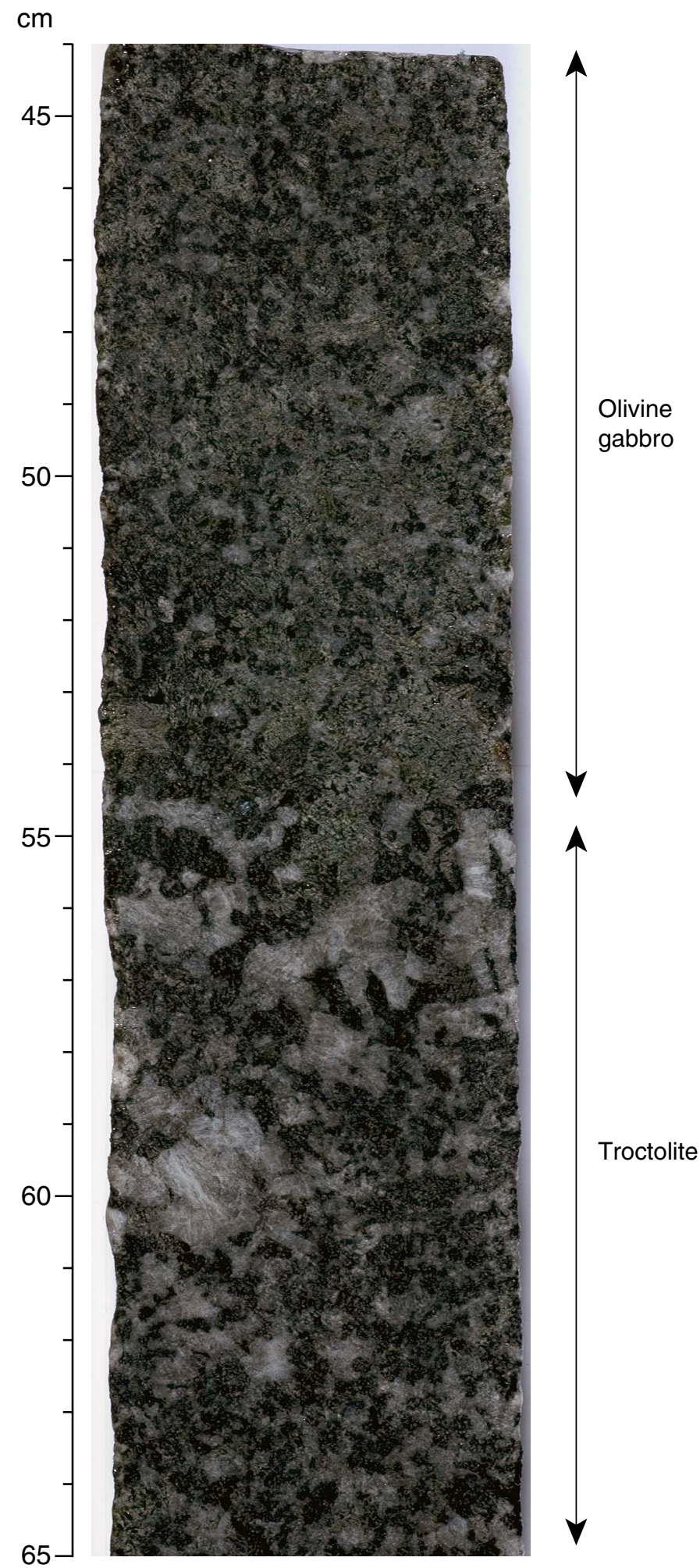


Figure F9. Examples of olivine-rich troctolite occurrence. A. Partially serpentinized olivine-rich troctolite in contact with olivine gabbro (interval 305-U1309D-227R-2, 22-45 cm). B. Fresh olivine-rich troctolite, cut by a gabbroic dikelet (interval 305-U1309D-248R-2, 2-26 cm).

$\mathbf{A}_{\mathrm{cm}}$

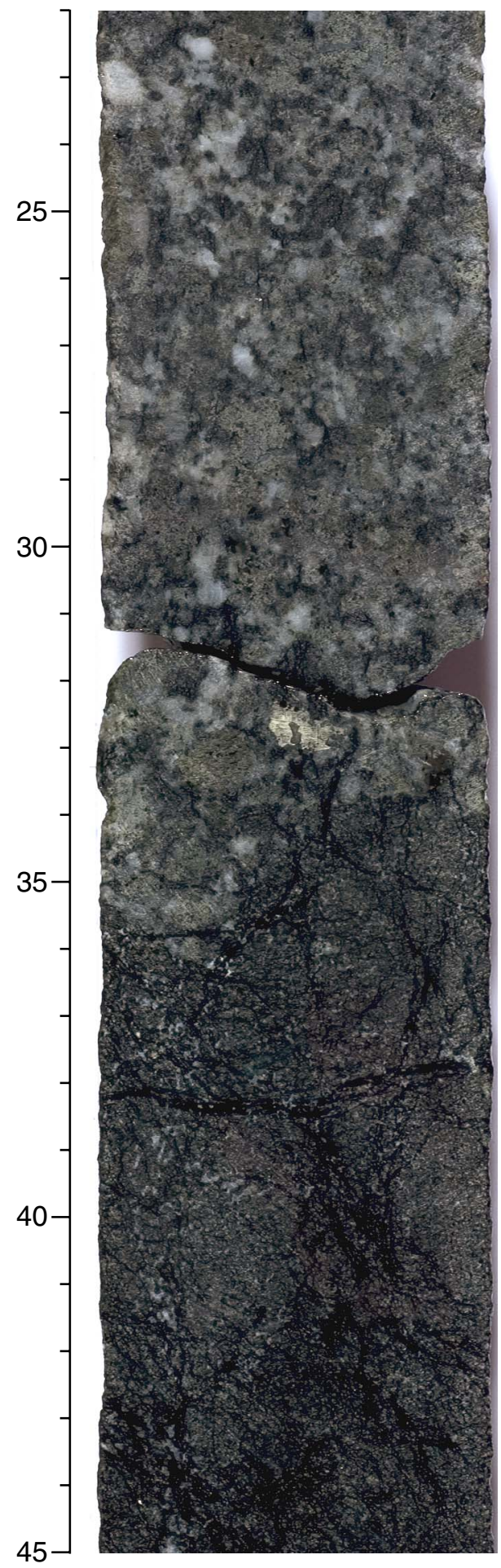

$\mathbf{B}_{\mathrm{cm}}$

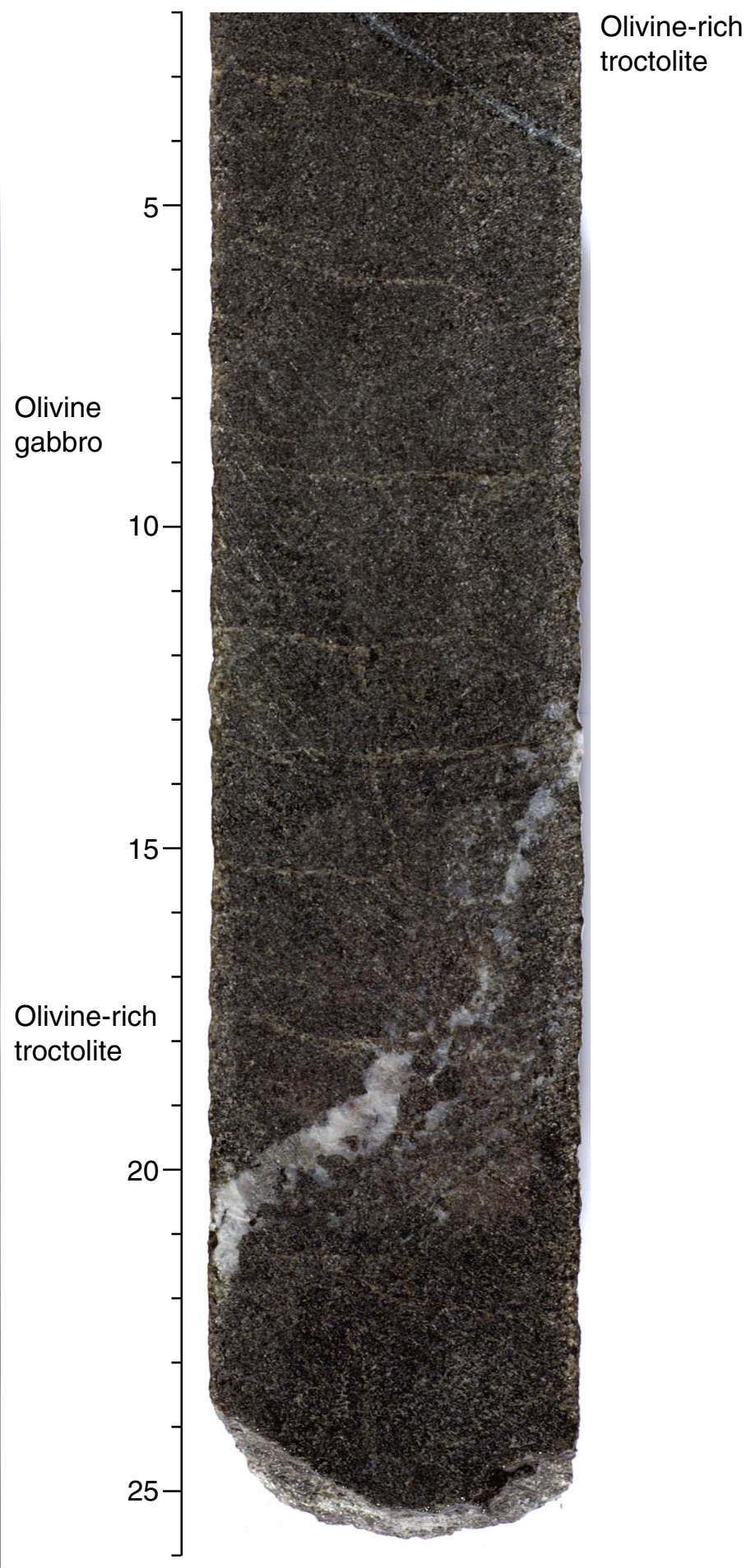


Figure F10. A. Plagioclase-bearing websterite (Sample 305-U1309D-100R-1, 10-13 cm) (cross-polarized light; field of view [FOV] = 22 mm). B. Olivine-rich troctolite (Sample 305-U1309D-227R-3, 70-72 cm) (cross-polarized light; FOV = $22 \mathrm{~mm}$ ). C. Olivine-rich troctolite (Sample 305U1309D-248R-2, 7-9 cm) (cross-polarized light; FOV = $22 \mathrm{~mm}$ ). D. Dunite (Sample 305-U1309D-248R-2, 96-99 cm) (cross-polarized light; FOV $=22 \mathrm{~mm})$. E, F. Close-up of fresh olivine and plagioclase in olivine-rich troctolite (Sample 305-U1309D-248R-2, 7-9 cm) (cross-polarized light; $\mathrm{FOV}=11 \mathrm{~mm})$
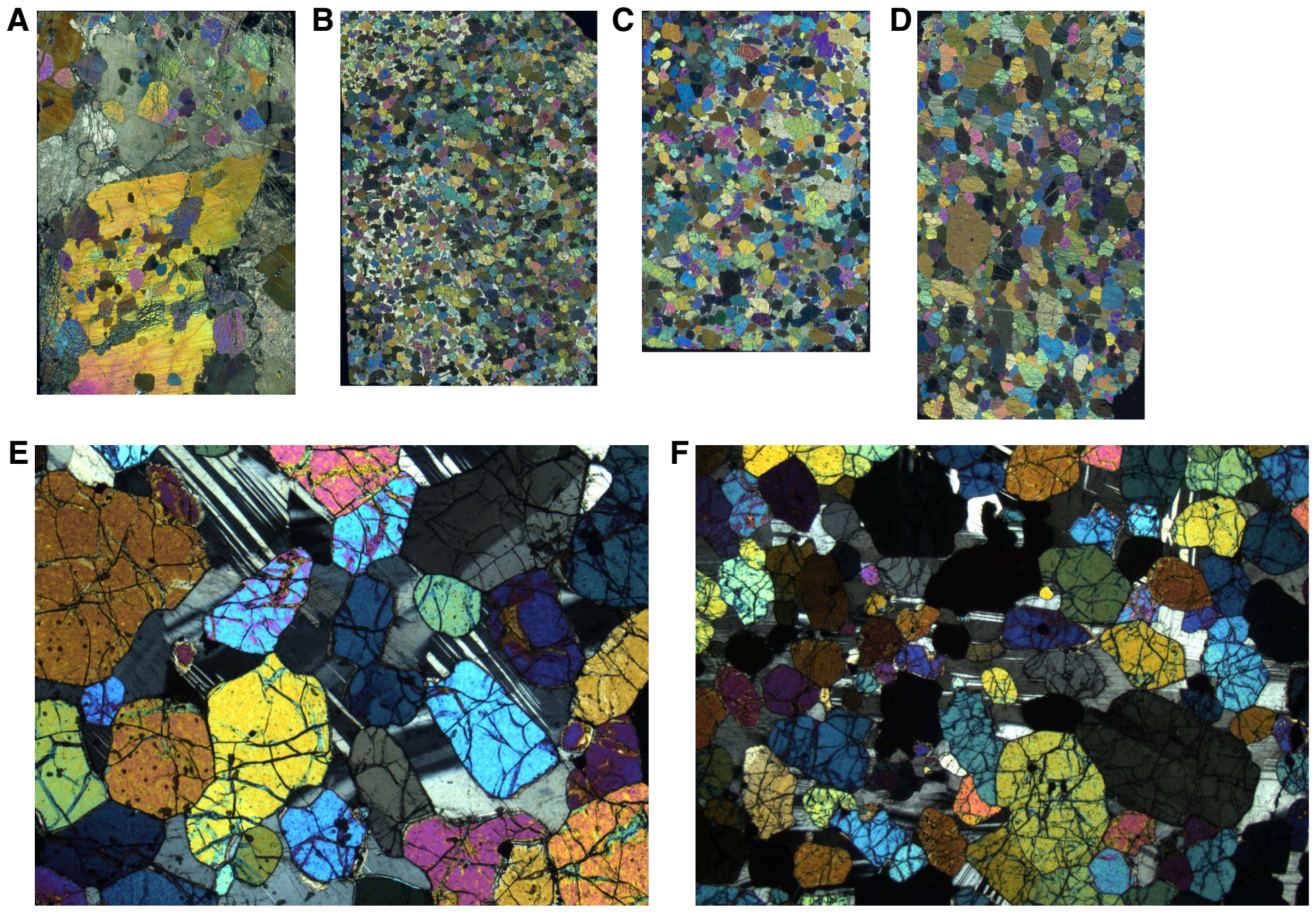
Figure F11. Modes of occurrence of oxide-rich gabbros. A. Oxide patches in magmatic texture (Sample 305U1309D-254R-1, 34-36 cm) (plane-polarized light; field of view [FOV] = $2 \mathrm{~cm}$ ). B. Same as A; cross-polarized light. C. Oxide-rich shear zone (Sample 305-1309D-183R-2, 32-34 cm) (plane-polarized light; FOV = $2 \mathrm{~cm}$ ). D. Same as C; cross-polarized light.
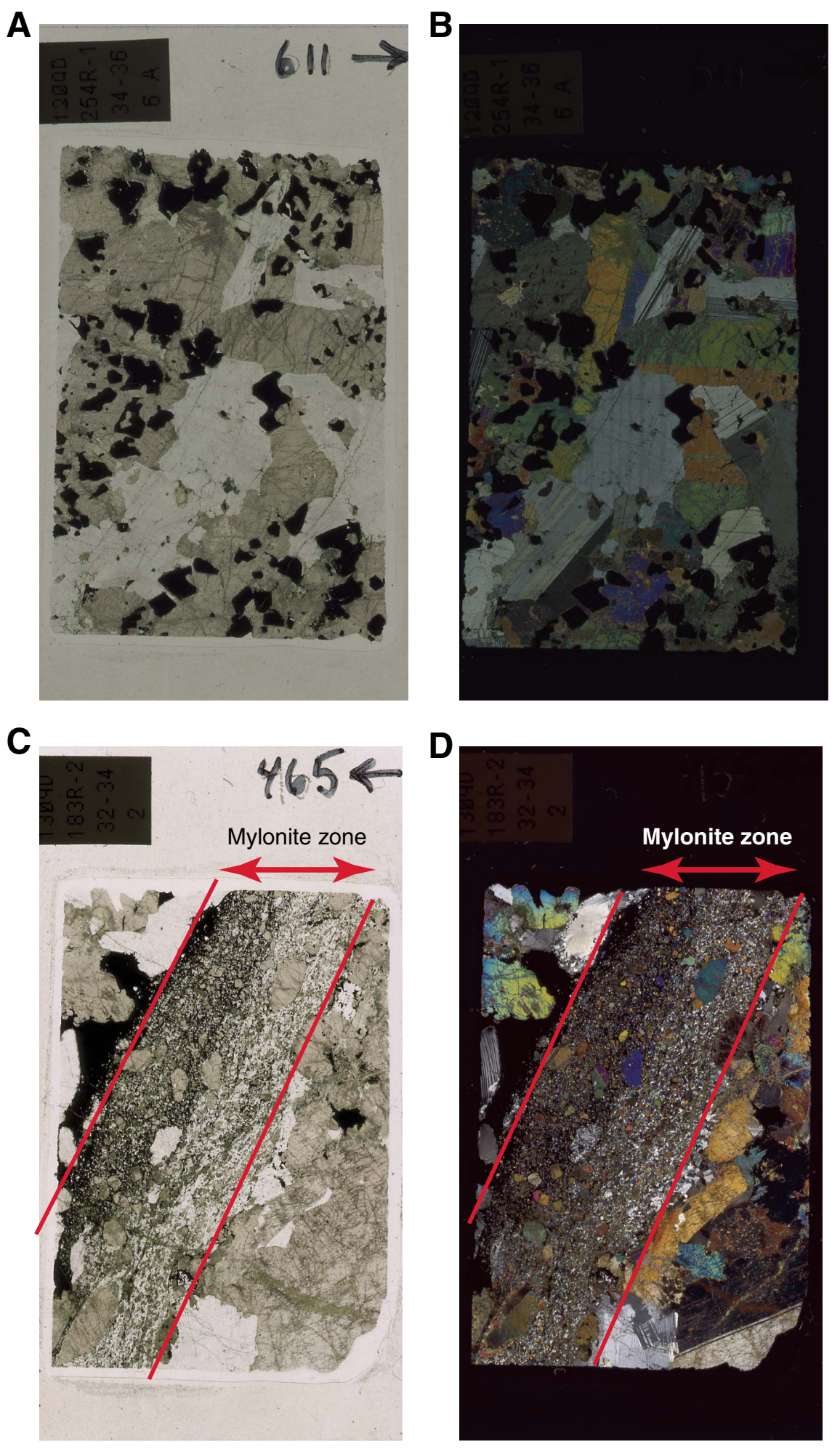
Figure F12. Magnetic susceptibility (MS) measured along half cores from Hole U1309B in diabase Unit 20 (Core 305-U1309D-19R). Edited data (blue) are measurements made $>5 \mathrm{~cm}$ from the edge of a core piece, so values are most reliable; however, overall pattern is the essentially the same as for all data (gray). Note the lower MS in the middle of this diabase unit (MS remains high in Core 305-U1309D-20R below 99 mbsf).

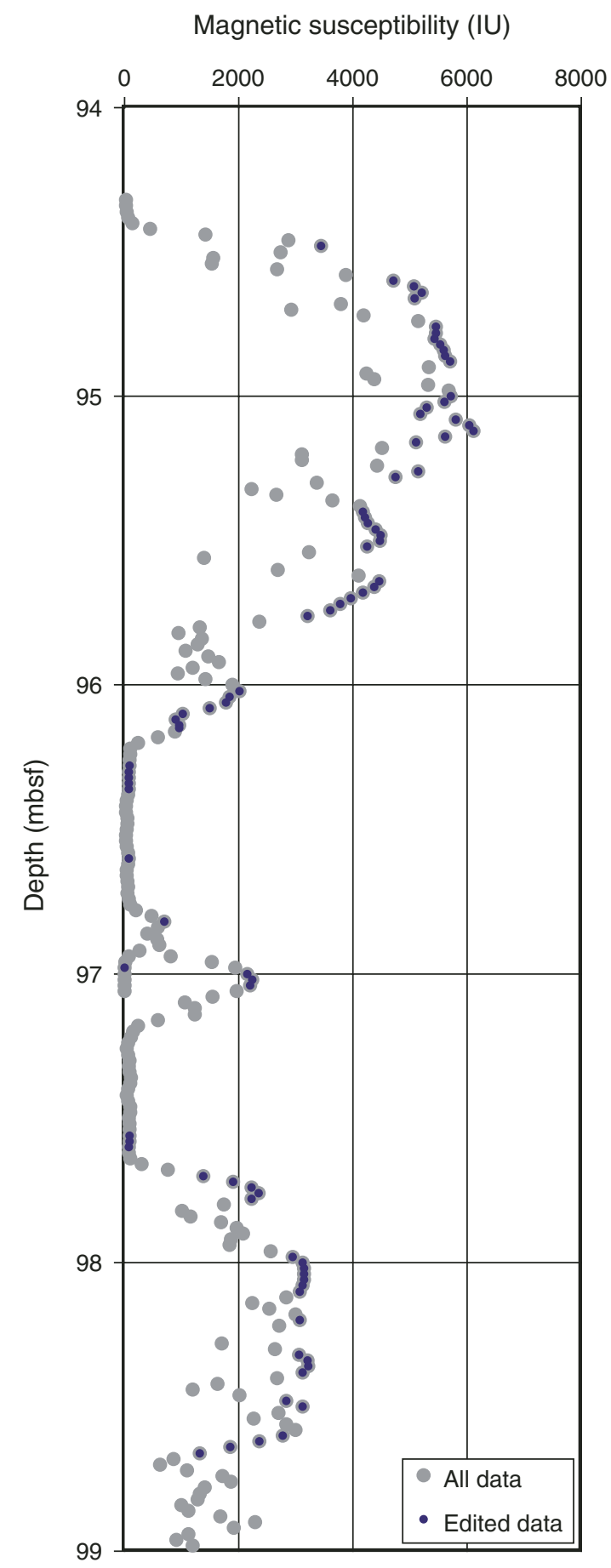


Figure F13. Termination of a late magmatic leucocratic vein in Core 304-U1309D-62R.

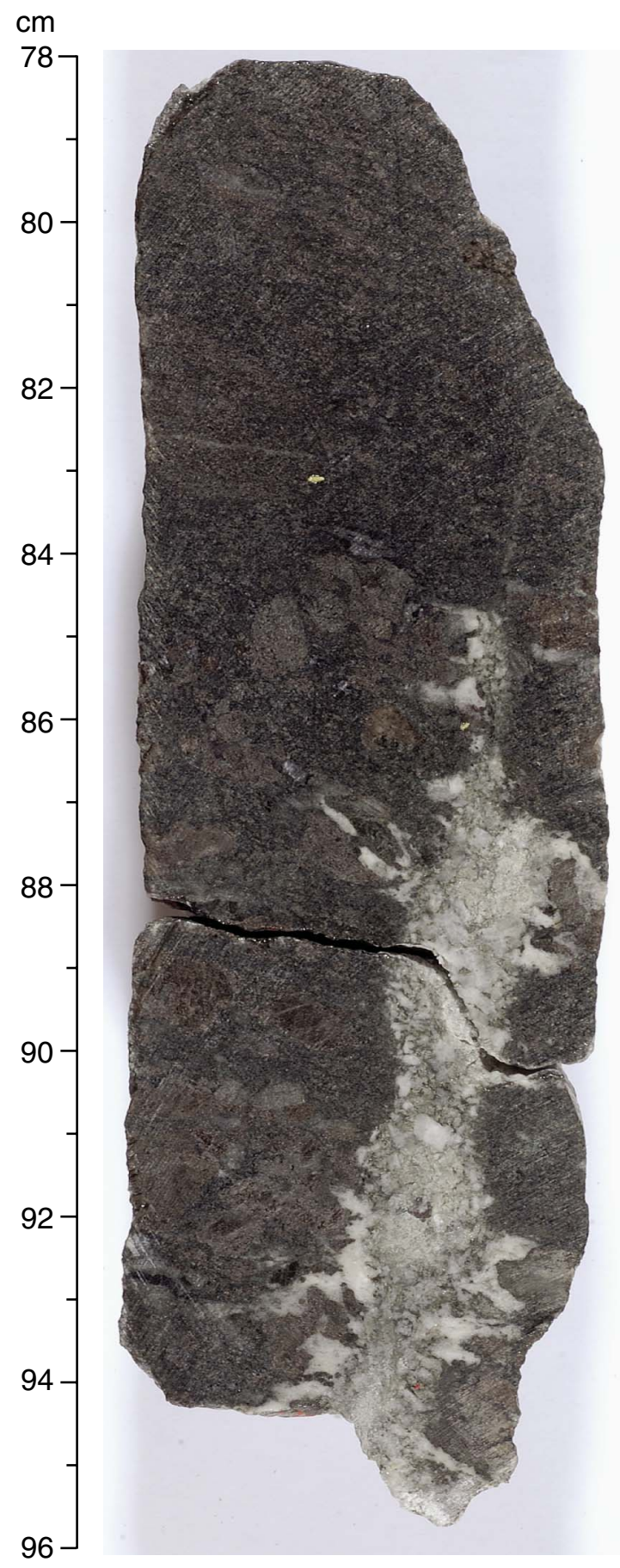


Figure F14. Ni versus Mg\# (molar Mg/[Mg + Fe]) for gabbros, olivine gabbros, troctolites, orthopyroxene-bearing gabbros, oxide-gabbros, ultramafic rocks, and peridotites from Site U1309. Shaded fields represent data from Leg 153 (peridotite = upper purple field; gabbro = lower purple field), Leg 209 (peridotite = upper yellow field; gabbro = lower yellow field), and Hole 735B (green field).

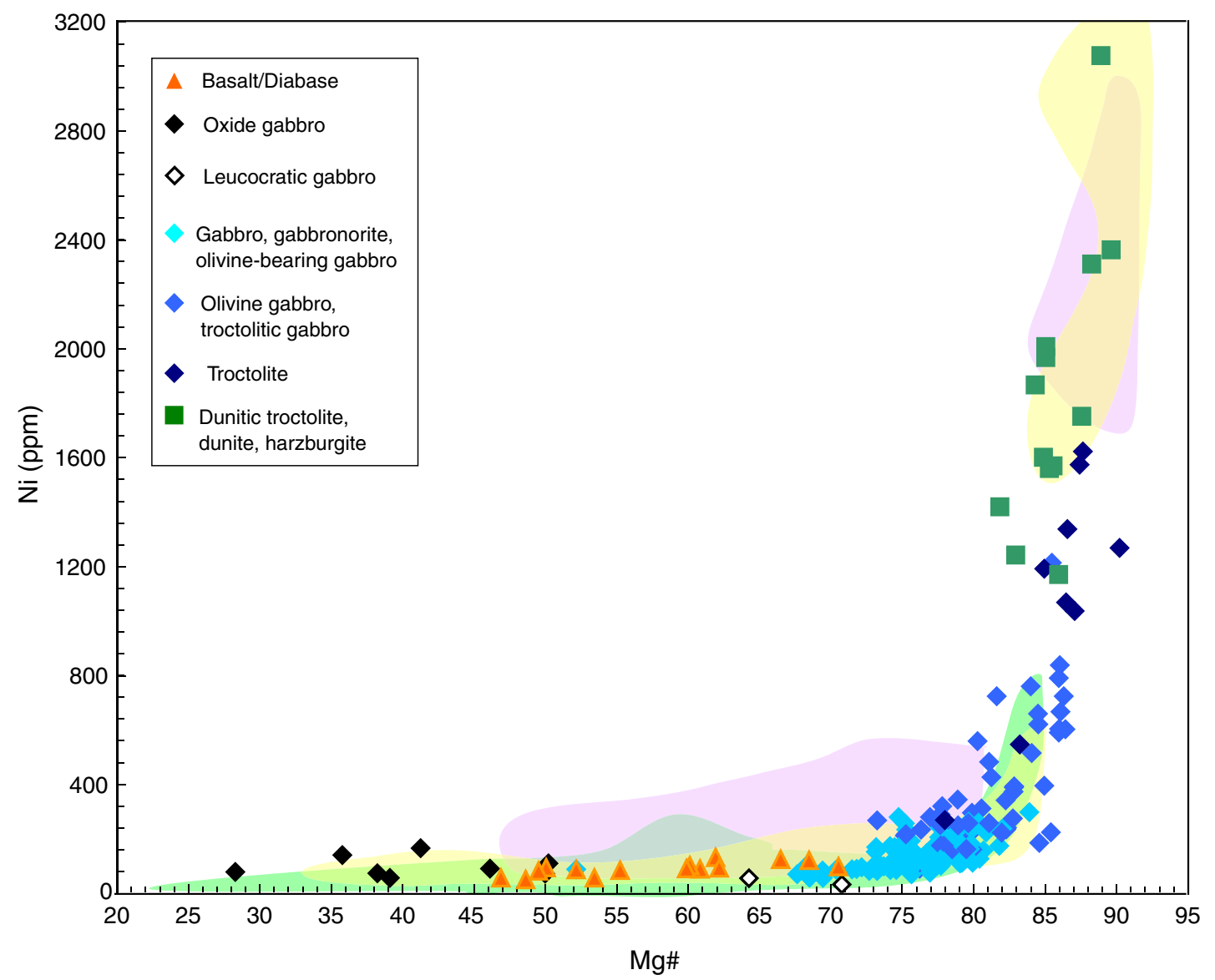


Figure F15. Downhole variations in whole-rock Mg\# for Hole U1309D core samples. Dashed lines = fault zones.

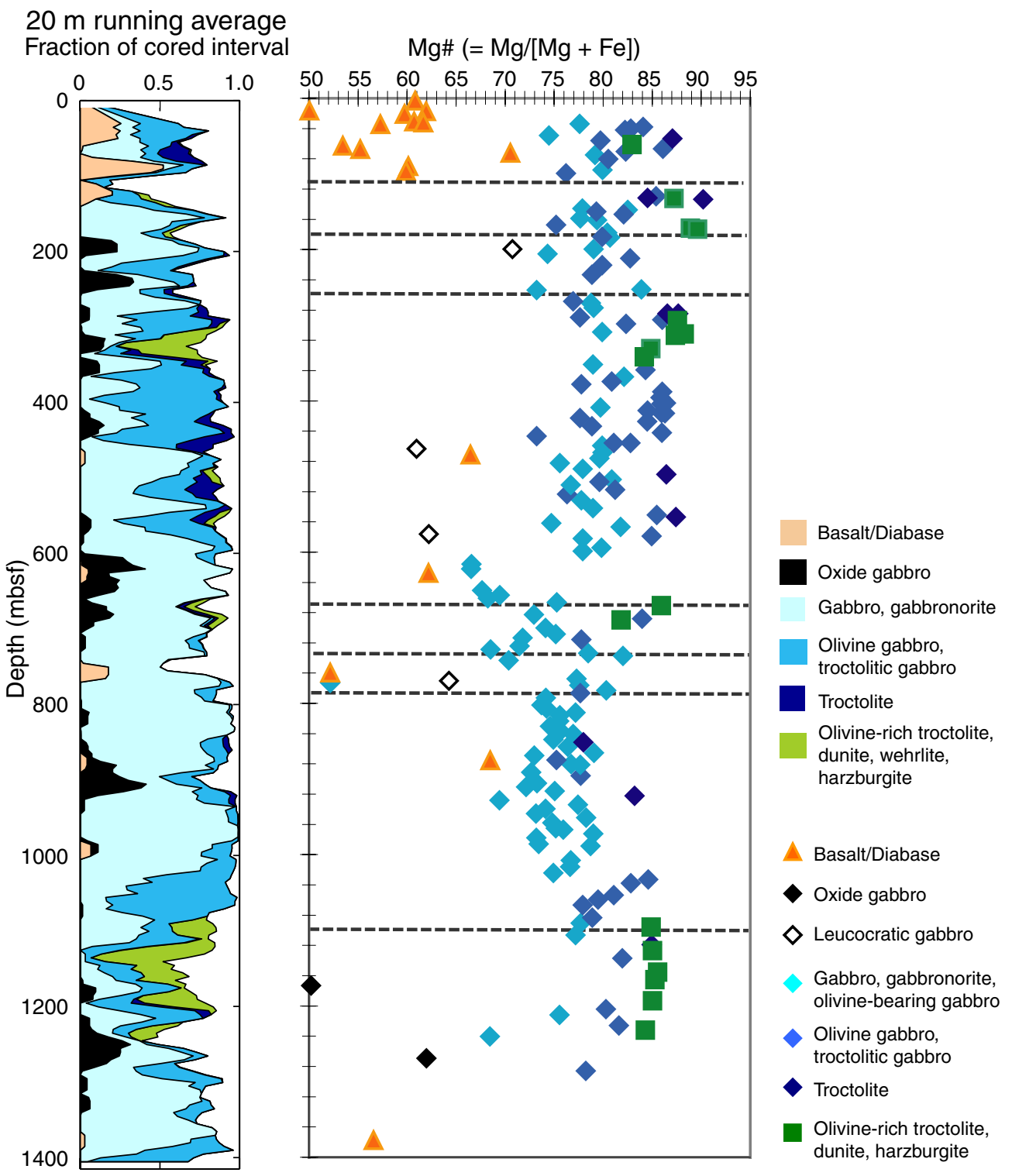


Figure F16. Total alkalis, $\mathrm{Na}_{2} \mathrm{O}+\mathrm{K}_{2} \mathrm{O}$, versus $\mathrm{SiO}_{2}$ (after Le Maitre et al., 1989). Data are plotted on a volatilefree basis for basalts, diabases, and basalt breccia from Holes U1309B and U1309D. Compilation of the compositions of Mid-Atlantic Ridge (MAR) glasses (PetDB, December 2004; www.petdb.org) is shown for comparison. The continuous line represents the alkalic/tholeiitic boundary of Irvine and Baragar (1971). Ol = normative olivine, $\mathrm{Q}=$ normative quartz.

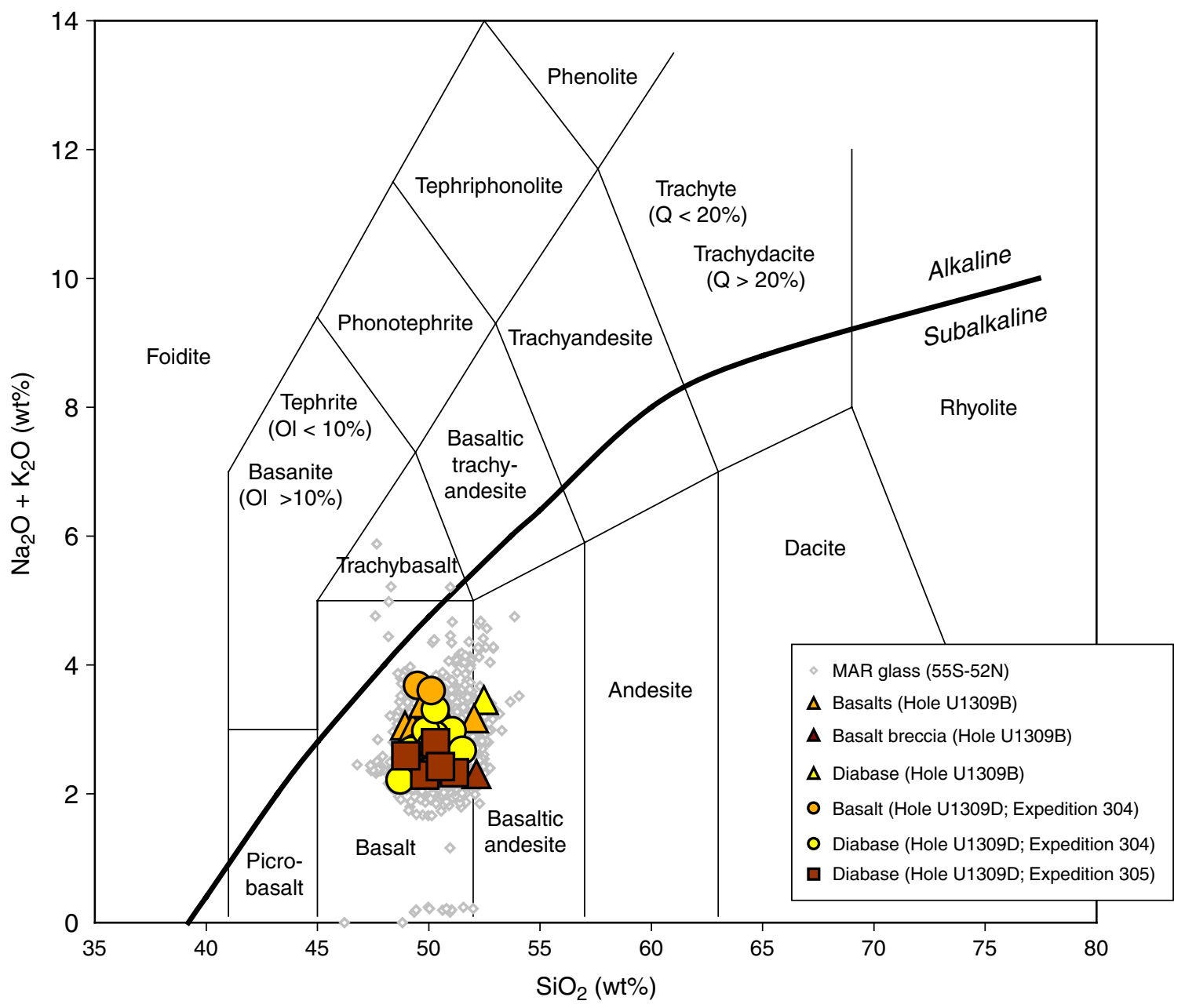


Figure F17. Downhole alteration and veining in Hole U1309D. A. Igneous lithology B. Overall alteration logged during visual core description (percent per core). C. Total number of veins per core.

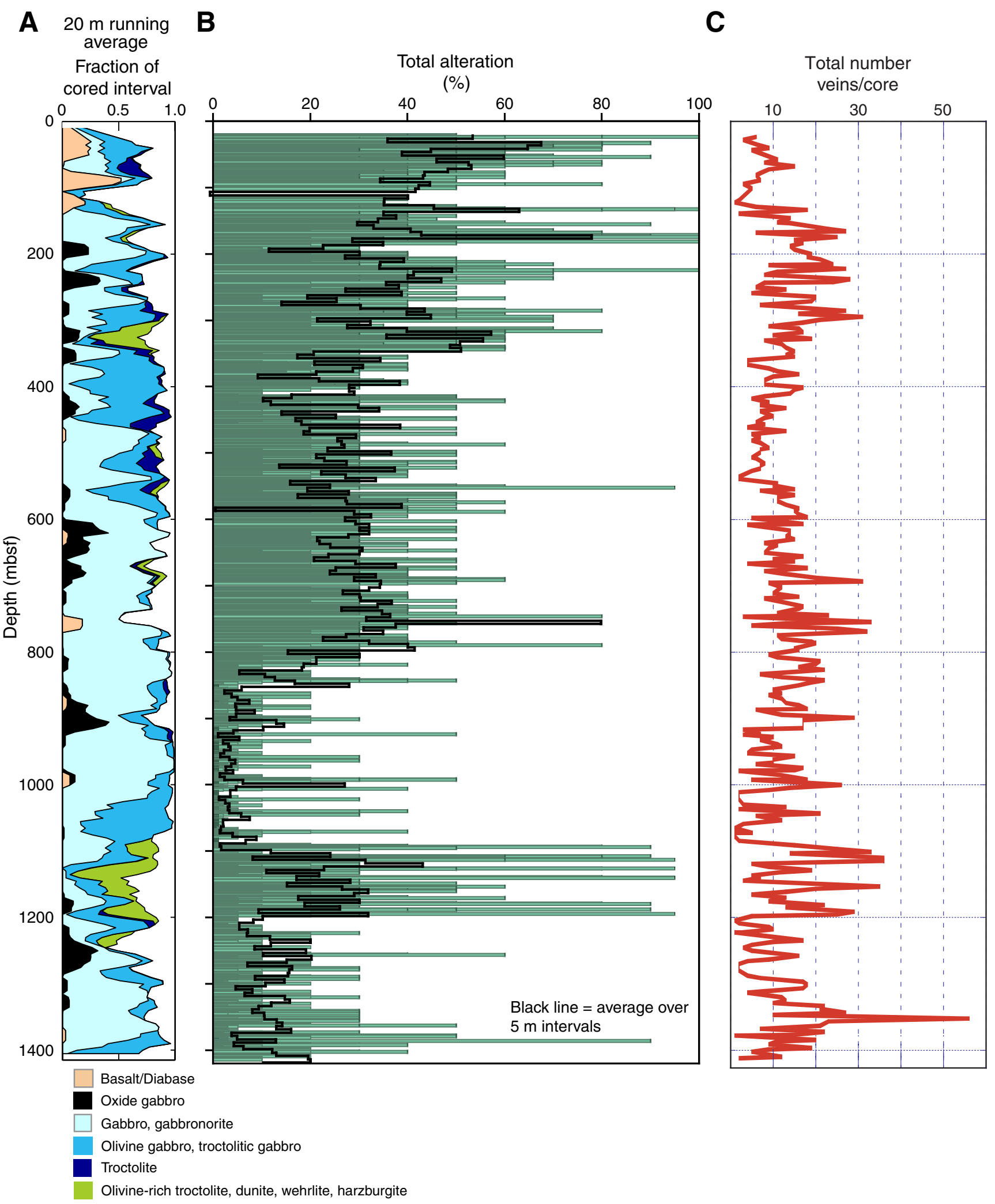


Figure F18. Examples of high-temperature, ductile deformation structure that is recorded in some Hole U1309D rocks. A. Whole thin section showing a well-defined mylonite in gabbro cut by a fracture (Sample 304-U1309D-8R-1, 68-71 cm) (plane-polarized light; field of view [FOV] $=\sim 2 \mathrm{~cm}$ ). B. Brown amphibole vein crosscuts highly localized shear zone in mylonite with domains of recrystallized plagioclase and pyroxene (Sample 304-U1309D-9R-1, 71-73 cm) (cross-polarized light; FOV = $4 \mathrm{~mm}$ ).
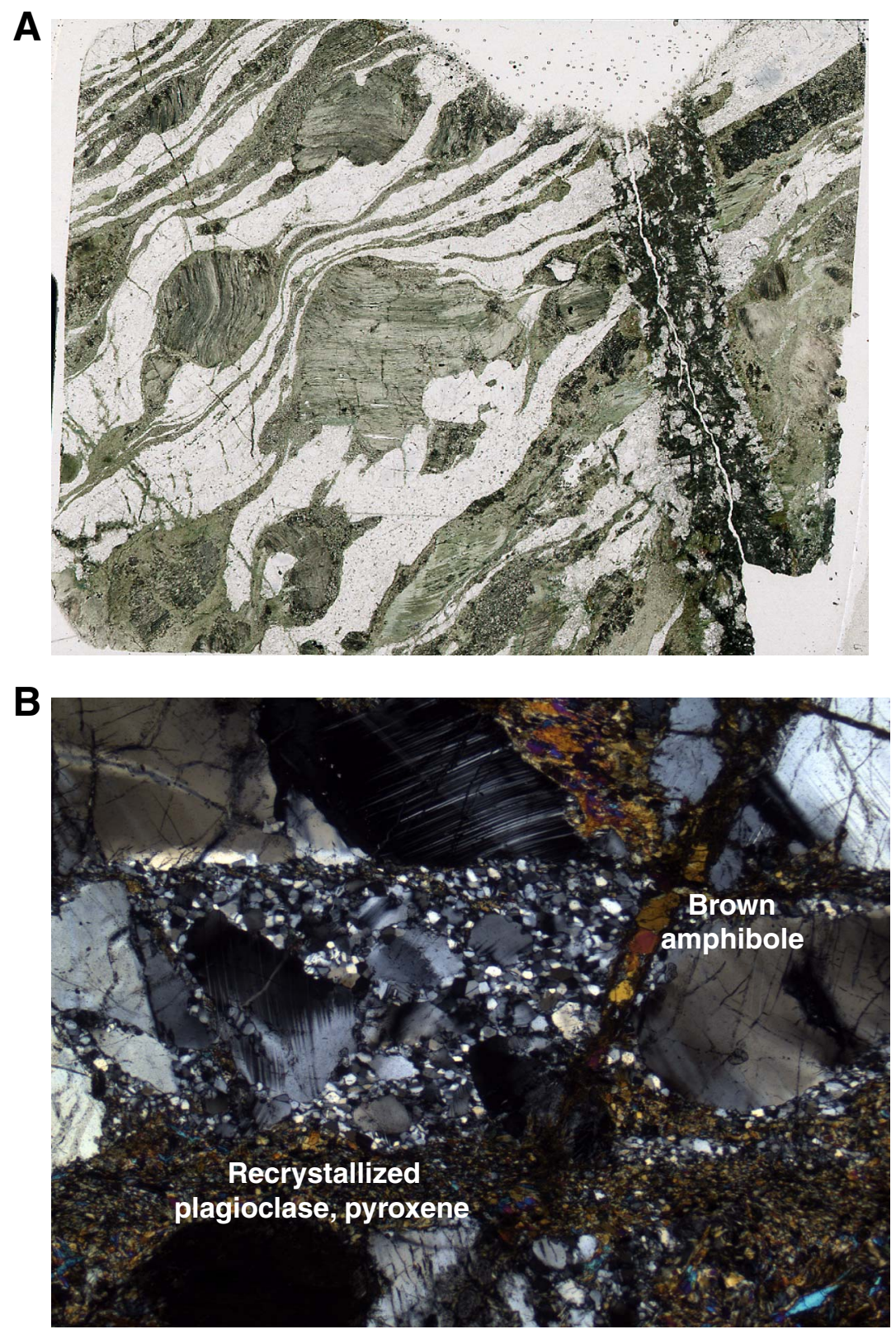
Figure F19. A. Dark green amphibole veins cutting gabbro (interval 305-U1309D-294R-2, 30-44 cm). B. Gabbro cut by parallel set of dark green amphibole veins (interval 305-U1309D-160R-4, 0-23 cm). The density of such sets locally approaches that of a foliation. Note development of corona texture in the alteration halo of these veins.

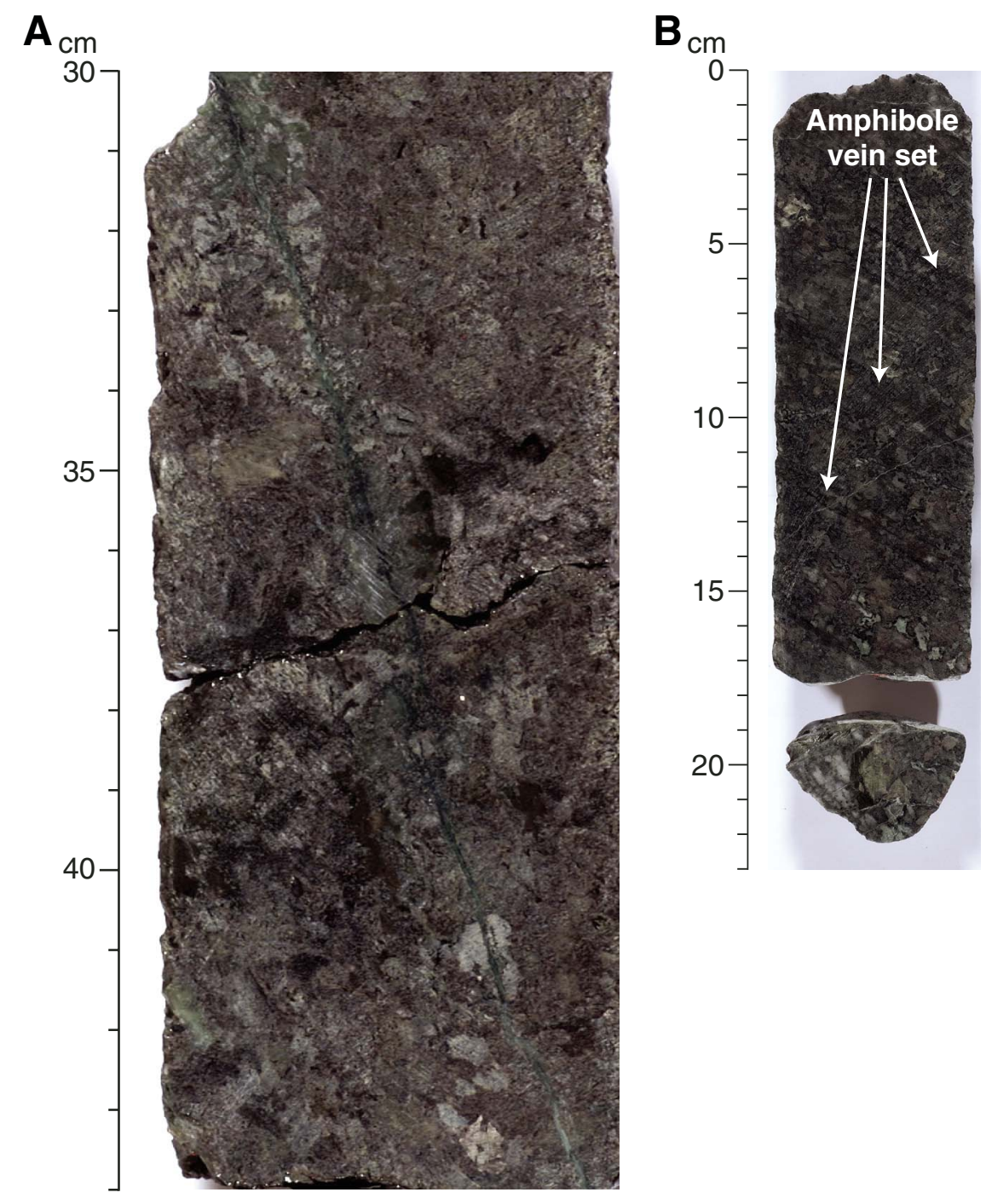


Figure F20. A. Troctolite layer showing well-developed corona mesh texture (interval 304-U1309B-15R-2, 53$64 \mathrm{~cm}$ ). Lighter green areas are actinolite after relict clinopyroxene. Original grain boundaries are outlined by dark green (appears black) chlorite. B. Corona texture in olivine gabbro consisting of talc, tremolite, oxides after olivine, and chlorite after plagioclase where the two original minerals were in contact (Sample 305U1309D-80R-2, 16-19 cm) (cross-polarized light; field of view = $1.4 \mathrm{~mm}$ ).

$\mathbf{A}_{\mathrm{cm}}$

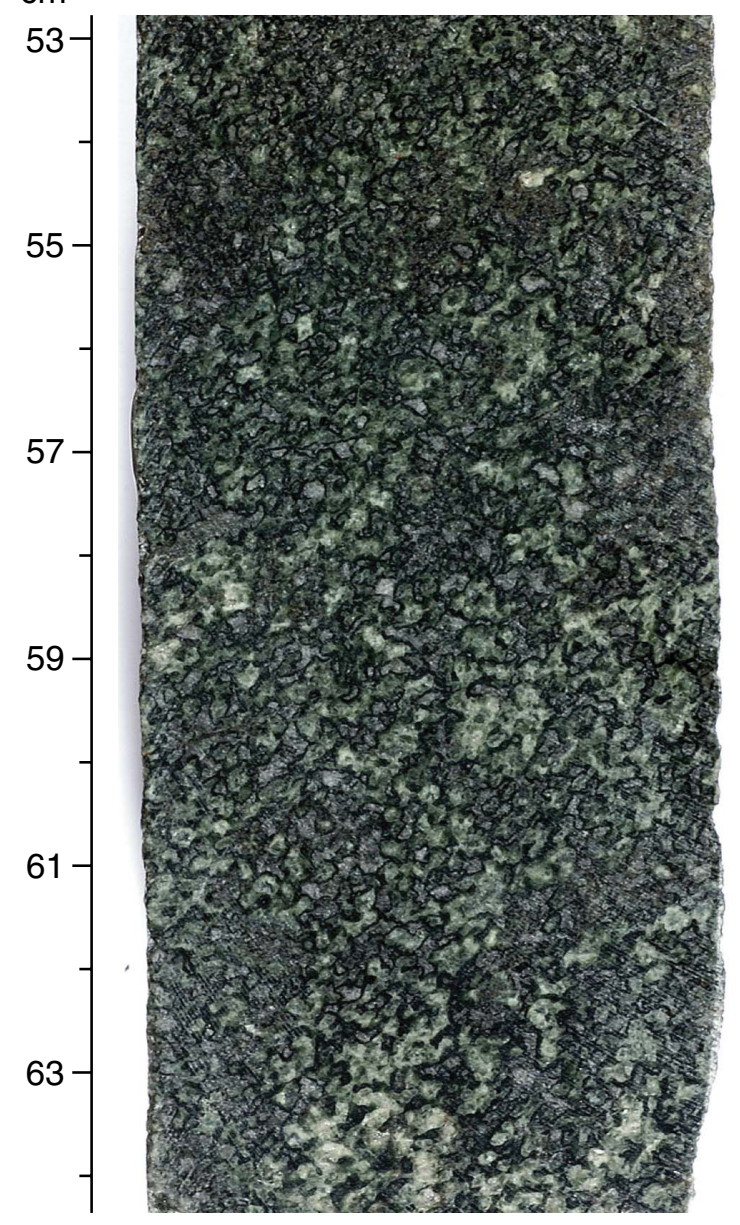

B

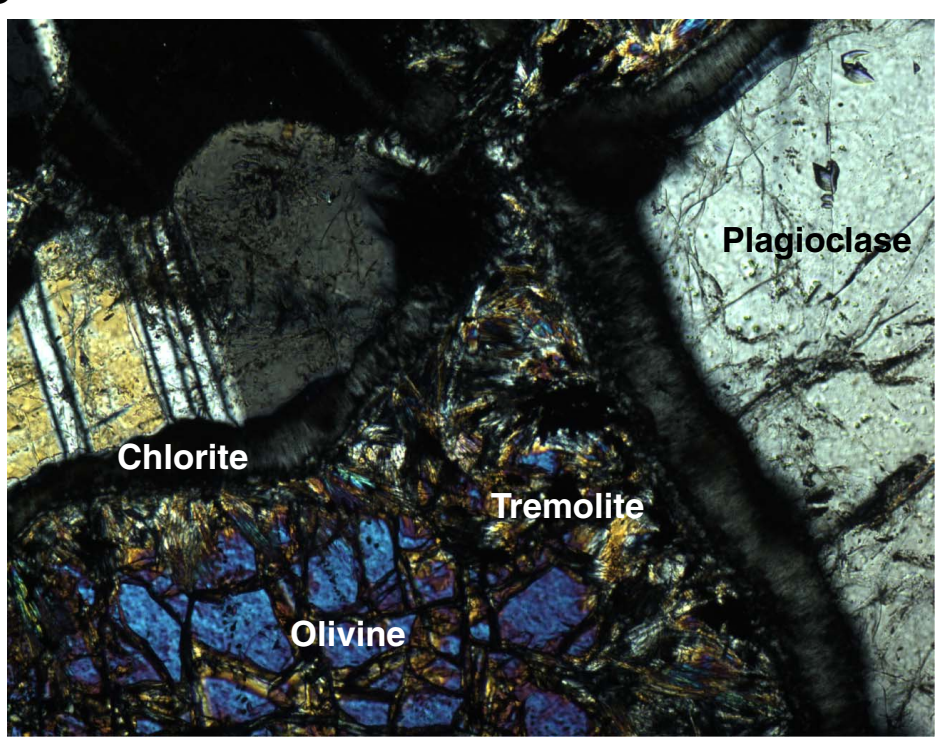


Figure F21. Contact between coarse-grained gabbro and harzburgite (interval 304-U1309B-11R-1, 86-99 cm). Note the talc-tremolite band between the two lithologies and the variations in serpentinization style.

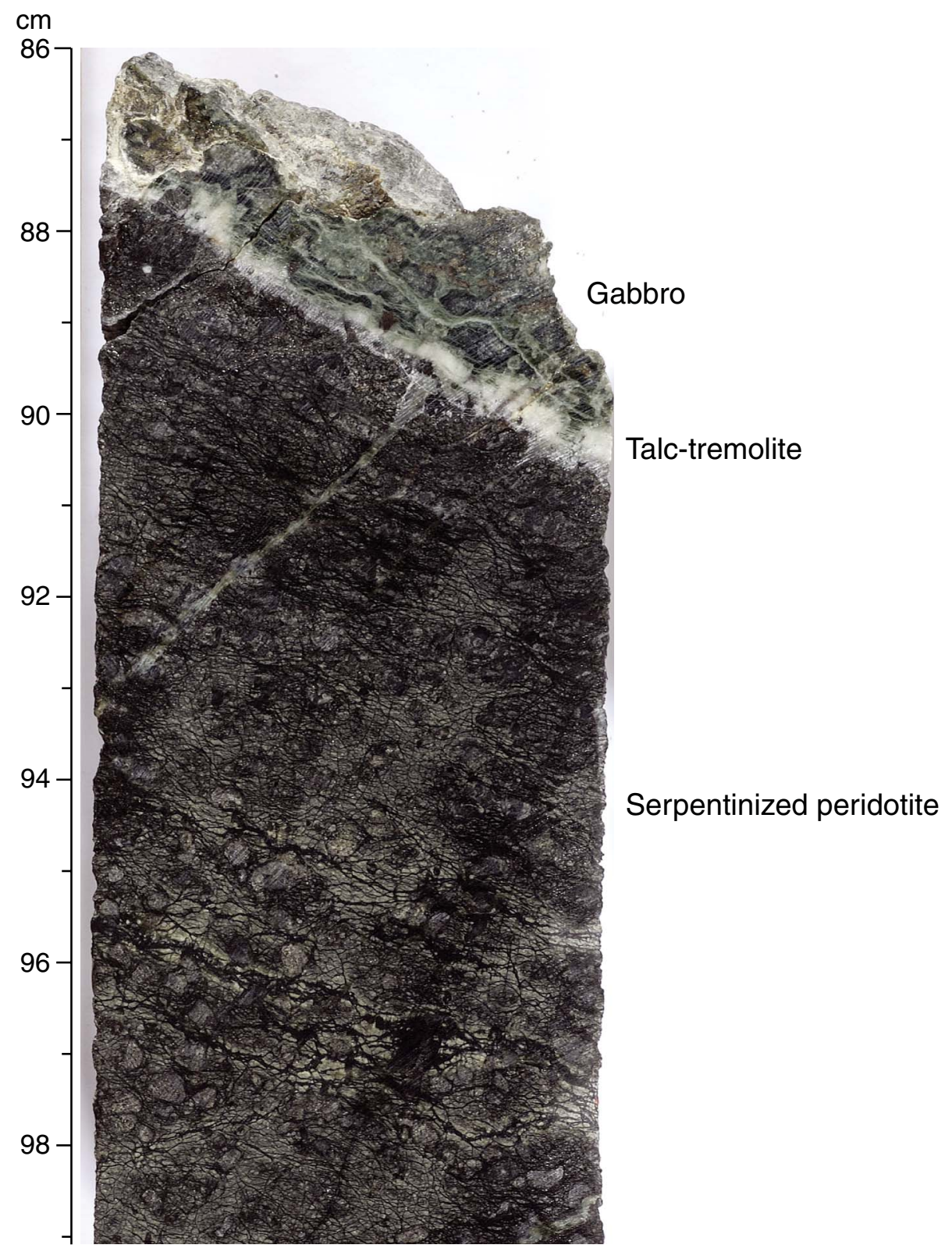


Figure F22. A. Serpentinized olivine with kernel texture (Sample 305-U1309D-80R-1, 39-41 cm) (planepolarized light; field of view $[\mathrm{FOV}]=5.5 \mathrm{~mm}$ ). B. Serpentine vein with dusty magnetite in olivine (Sample 305-U1309D-236R-2, 10-13 cm) (cross-polarized light; FOV = $700 \mu \mathrm{m}$ ).
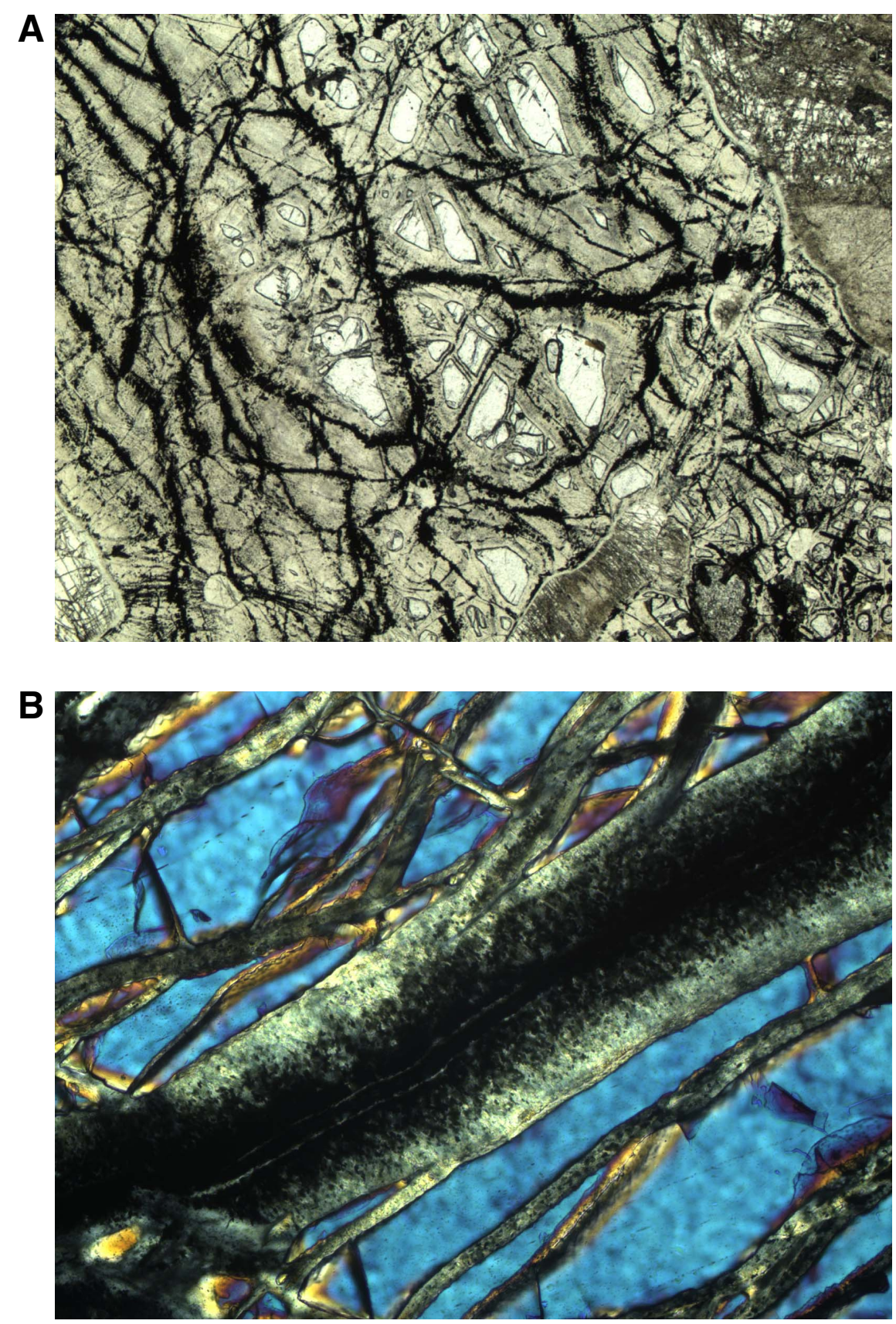
Figure F23. A. Metamorphic expansion microfractures in plagioclase adjacent to serpentinized olivine (Sample 305-U1309D-82R-2, 110-112 cm) (field of view $[\mathrm{FOV}]=5.5 \mathrm{~mm}$ ). B. Serpentinization-induced microfracturing (Sample 305-U1309D-232R-1, 102-105 cm) $(\mathrm{FOV}=5.5 \mathrm{~mm})$.

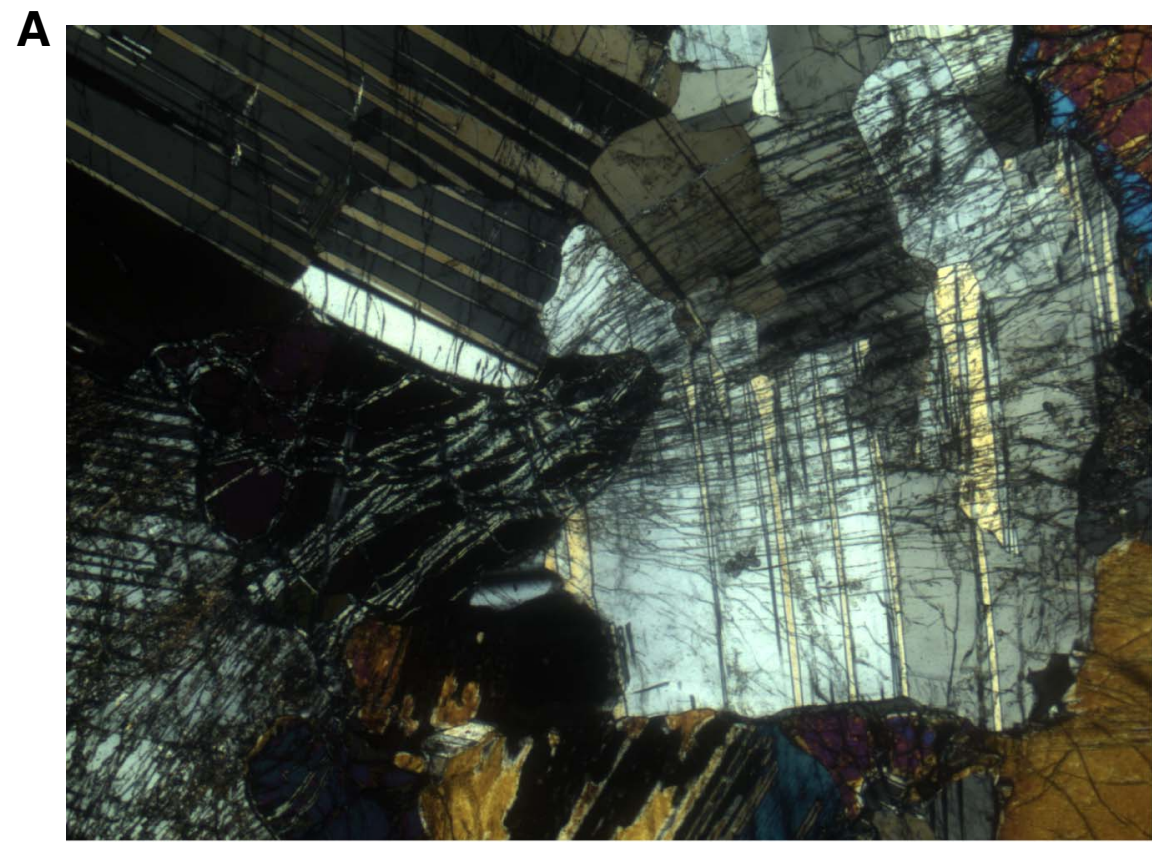

B

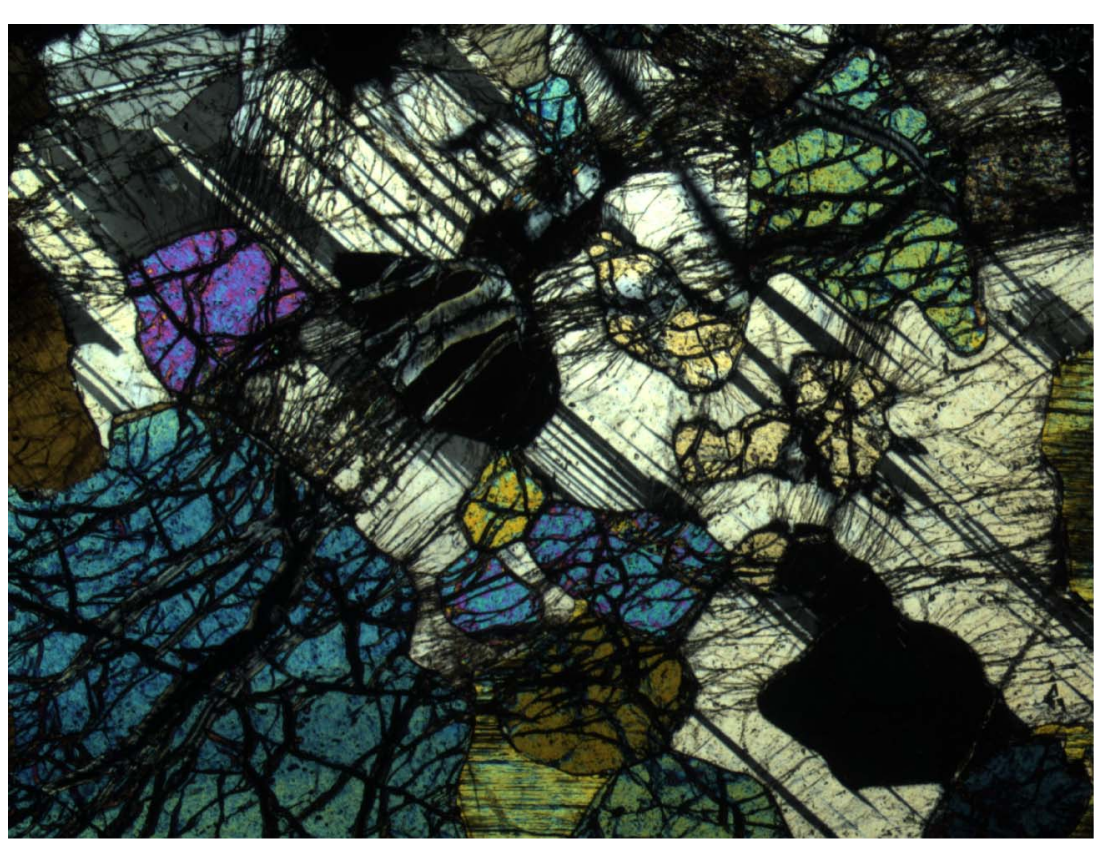


Figure F24. Prehnite vein with zeolite spherules projecting from the vein wall (Sample 305-U1309D-192R-1, $80-82 \mathrm{~cm}$ ) (cross-polarized light; field of view $=1.4 \mathrm{~mm}$ ).

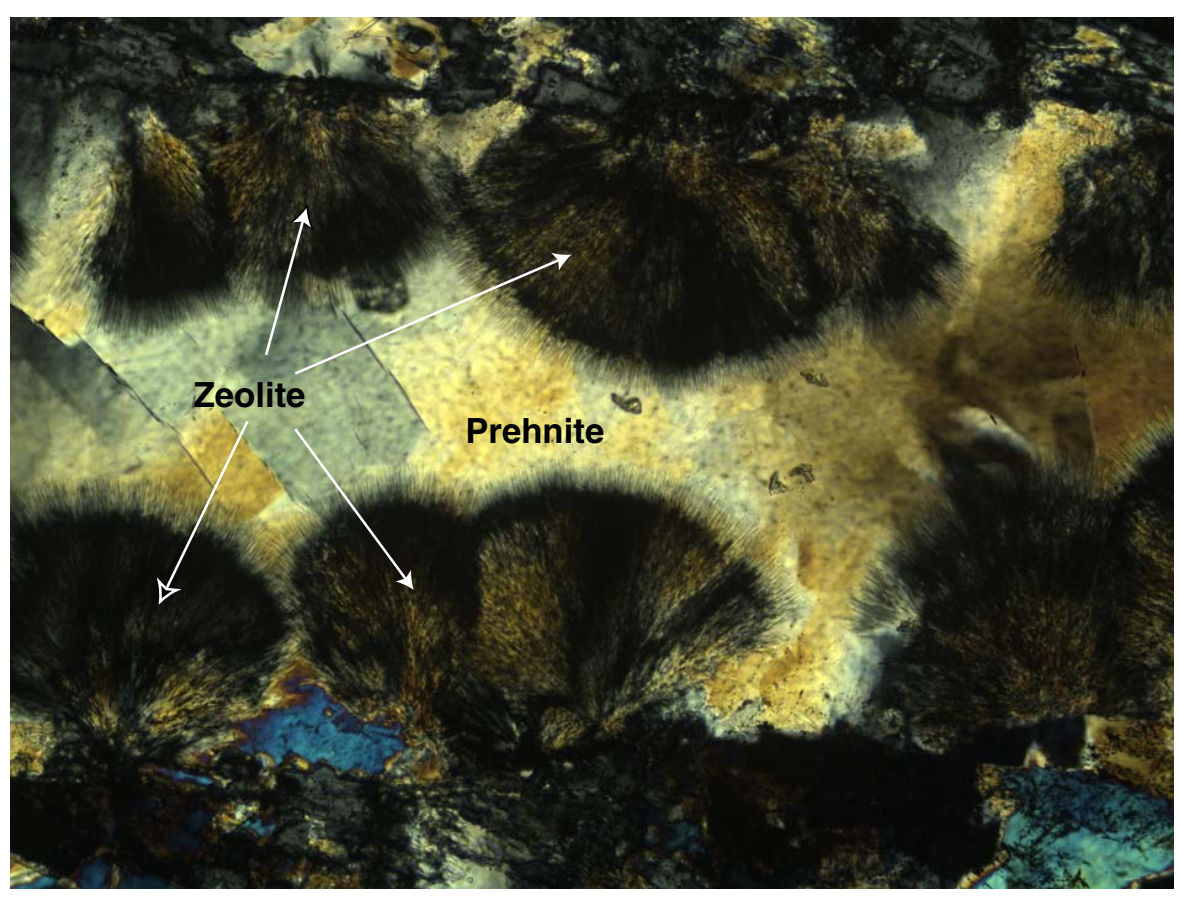


Figure F25. Synthetic seismogram model derived from Hole U1309D logging measurements and comparison to a section of MCS reflection Line Meg-4 (Fig. F2). A. Two-way traveltime-to-depth based on VSP check shot data to $750 \mathrm{mbsf}$ and an assumed value at $1415 \mathrm{mbsf}$. B. Conversion of logging $P$-wave velocity to traveltime at depth. C. Logging bulk density. D. Time-depth scales. E. Reflectivity model derived from data from B and C with bottom velocity value assumed. $\mathrm{RC}=$ reflectivity coefficient, which indicates impedance contrast. F. Wavelet convolved with reflectivity model. G. Resulting synthetic seismogram. H. Synthetic seismogram trace overlain on section of MCS Line Meg-4 at projected location of Hole U1309D. SP = shotpoint.

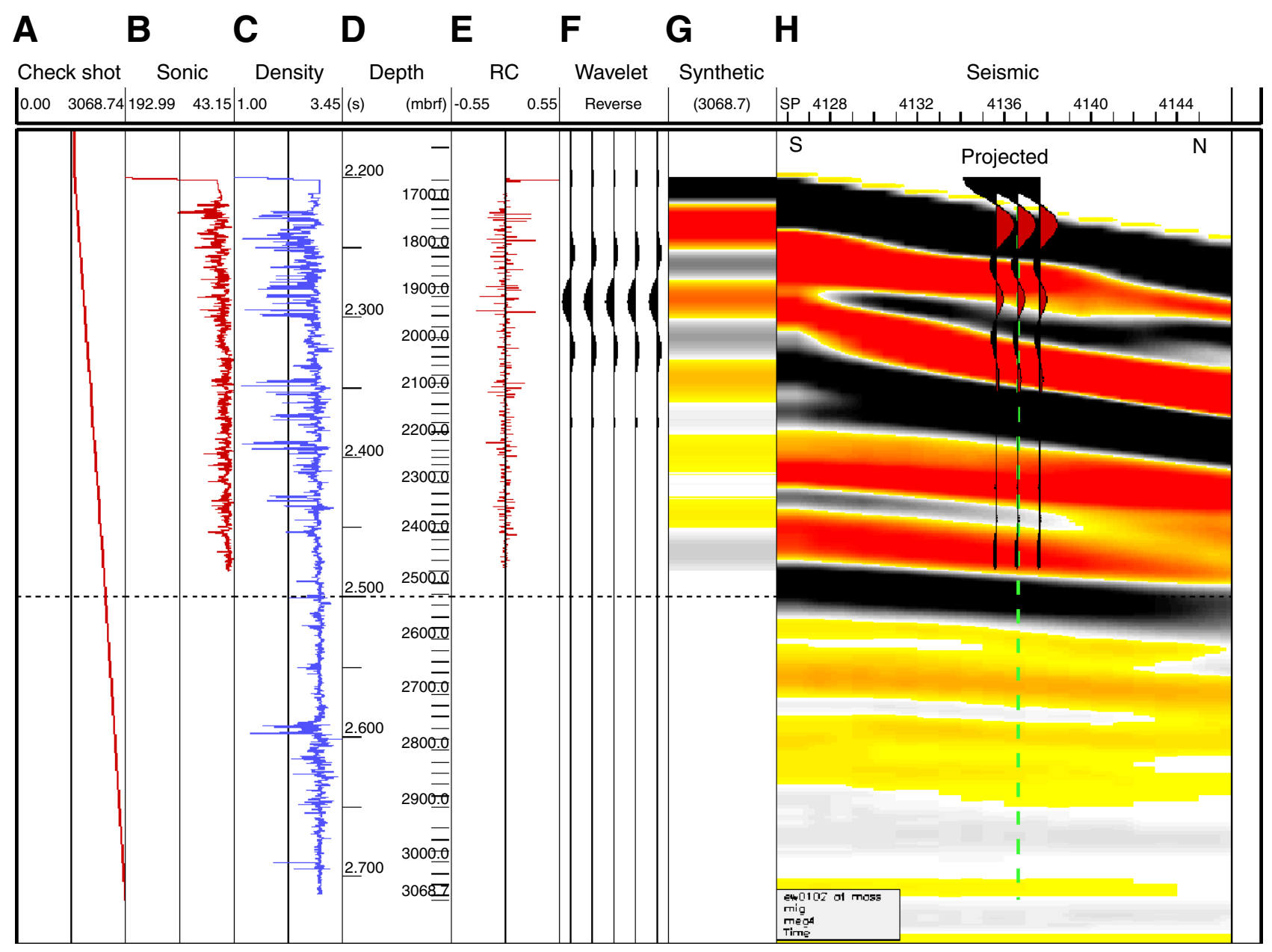


Figure F26. Example of magmatic foliation (Sample 305-U1309D-222R-2, 84-87 cm) (cross-polarized light; field of view $=22 \mathrm{~mm}$ ). About $22 \%$ of all recovered rocks show a weak magmatic foliation.

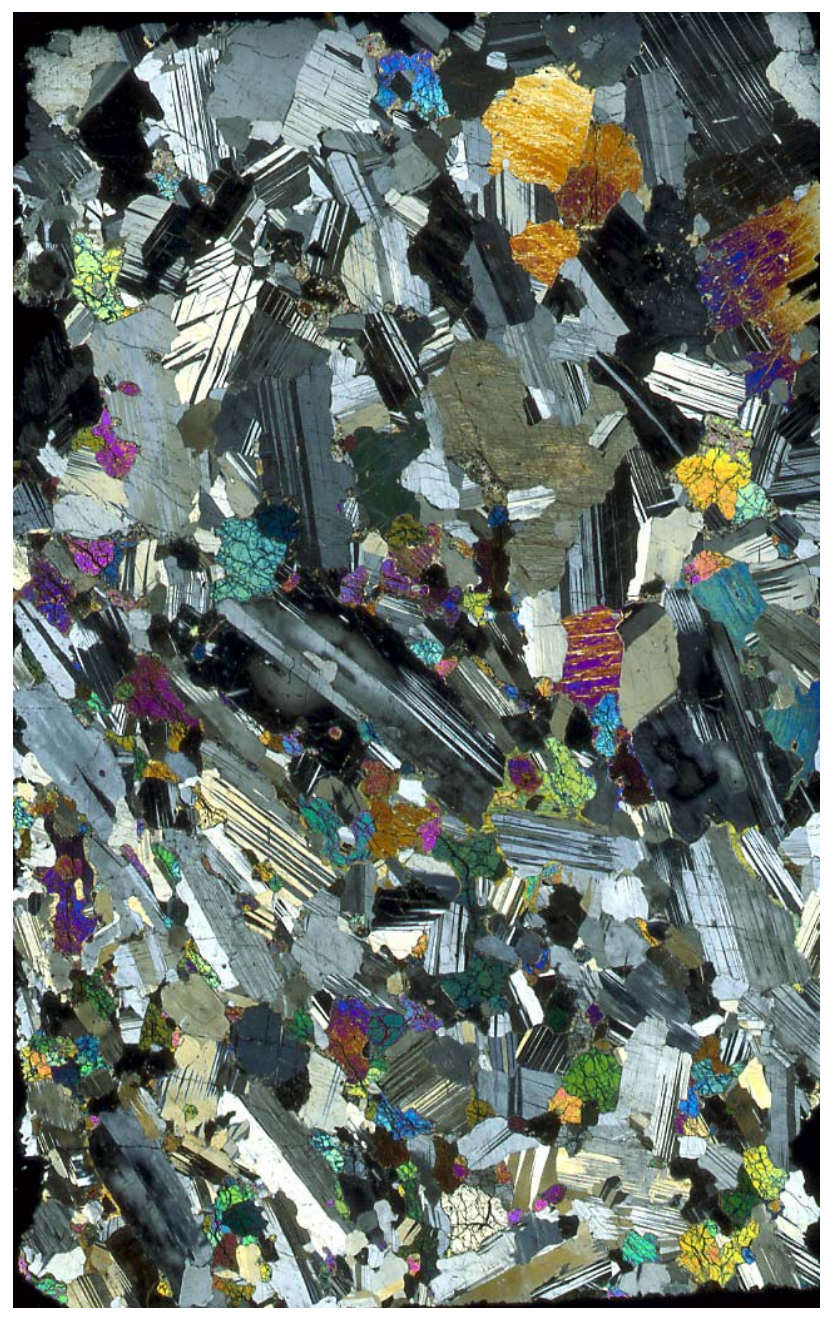


Figure F27. High-temperature plastic deformation foliation (Sample 305-U1309D-263R-2, 34-37 cm) (crosspolarized light; field of view $=\sim 2 \mathrm{~cm}$ ). Although core descriptions suggest an absence of plastic deformation except for local shear zones, microstructural observations commonly indicate a weak to moderate crystal-plastic strain overprint in samples selected to be representative of primary igneous texture.

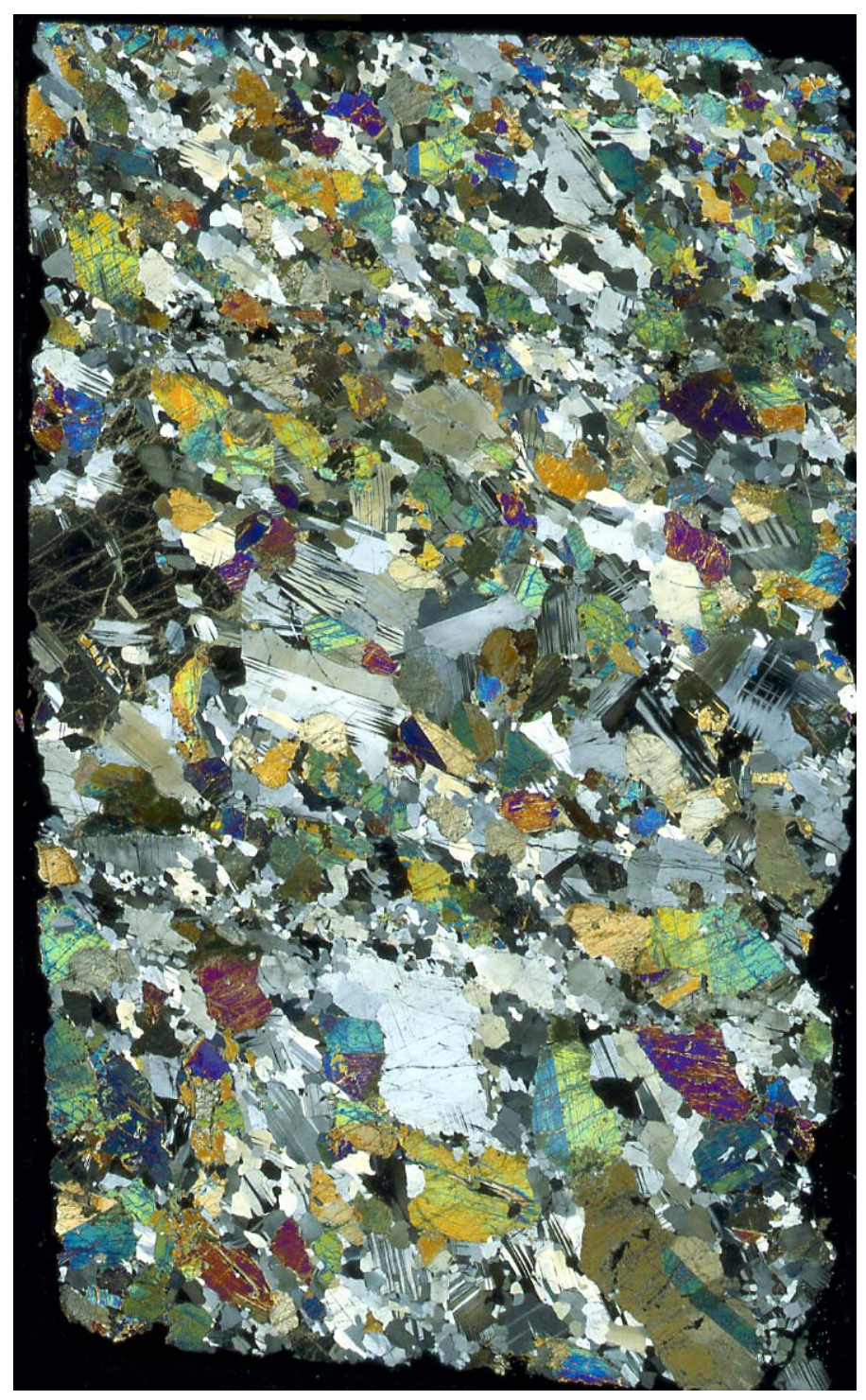


Figure F28. Serpentine foliation (interval 305-U1309D-235R-2, 98-113 cm).

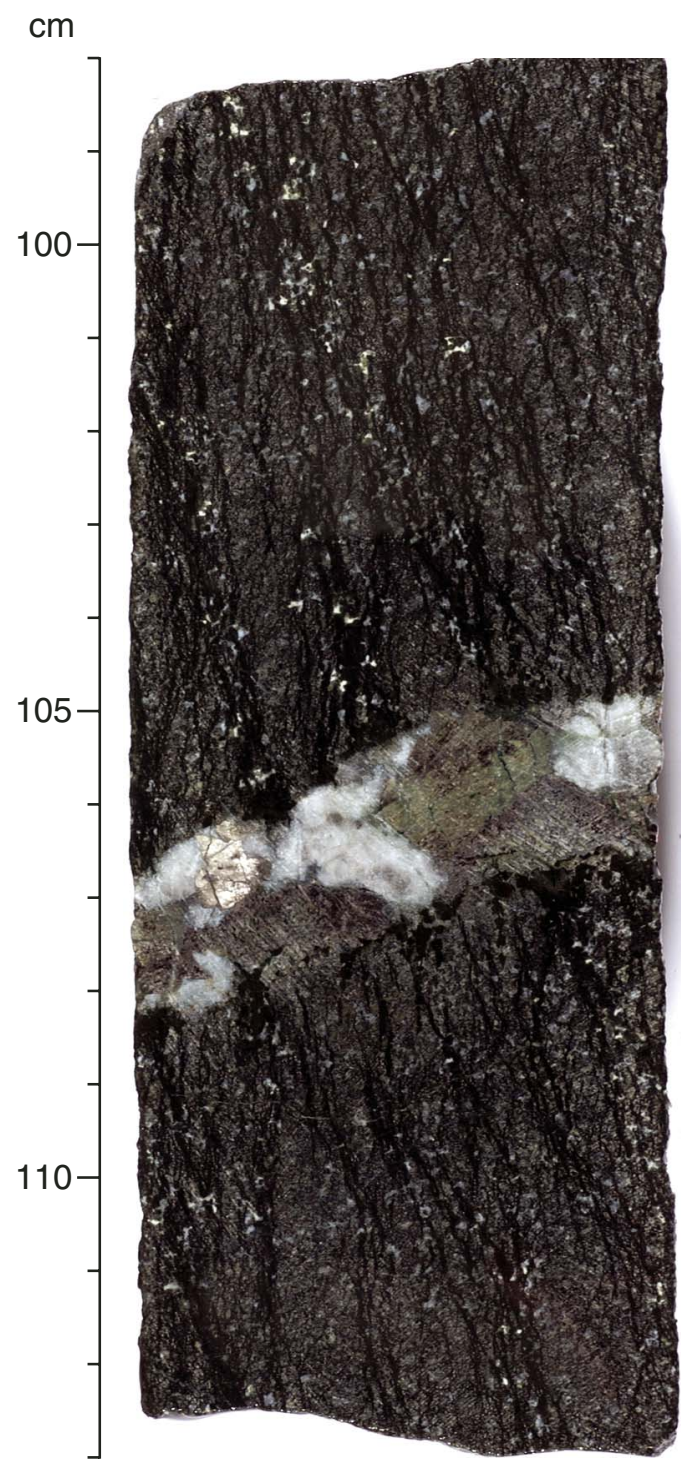


Figure F29. Downhole plots of structural features of Hole U1309D. A. Lithostratigraphy. B. Average intensity of magmatic and plastic foliation from core observations. C. Paleomagnetic inclination from archive-half and discrete samples. Groups $1-5$ correspond to zones with distinct average inclinations. Parts D-I are a summary of deformation in the upper $400 \mathrm{~m}$. D. Lithology. E. Intensity of magmatic fabrics $(3=$ strong shapepreferred orientation). F. Intensity of crystal-plastic fabrics $(4-5=$ mylonitic-ultramylonitc). G. Frequency of alteration veins $(5=>20 / \mathrm{cm})$. H. Intensity of cataclastic fabrics ( 5 = cataclasite). I. Magnetic inclination deduced from core samples that have been demagnetized to remove drilling overprint.

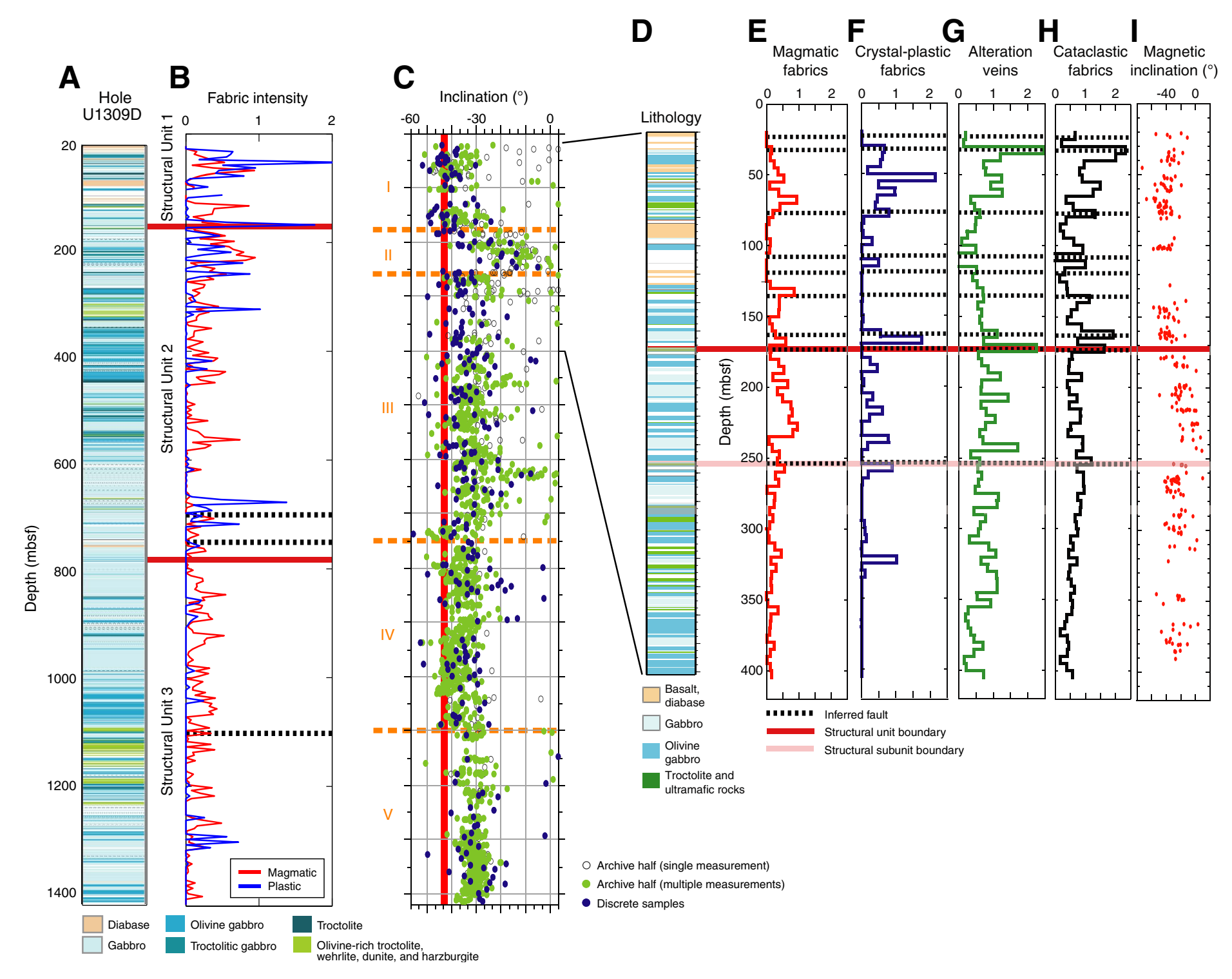


Figure F30. Section of moderately dipping, reverse sense zone of cataclasis at 760 mbsf (interval 305-U1309D$152 \mathrm{R}-1,1-22 \mathrm{~cm})$. The zone is overprinted by greenschist-facies mineralogy.

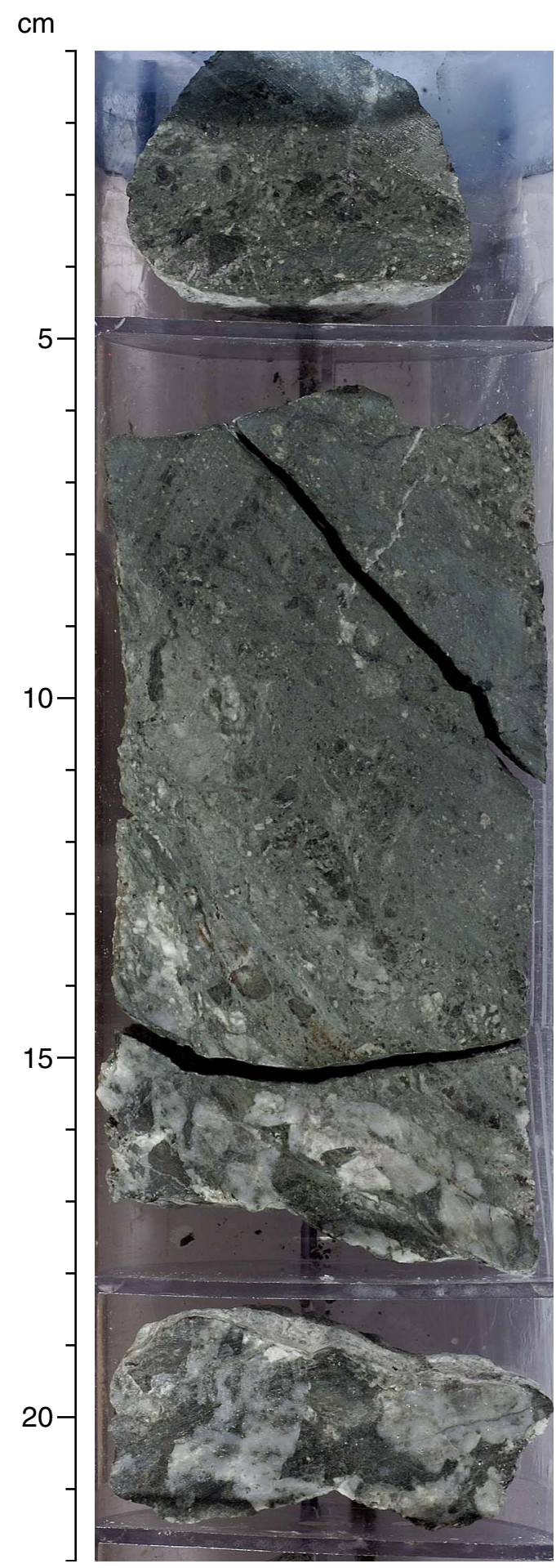


Figure F31. Downhole variation in magnetic properties and relationship to lithology and alteration. A. Lithology. B. MST magnetic susceptibility. C. Serpentinization foliation intensity measured by the structural team illustrates regions where degree of serpentinization is high.

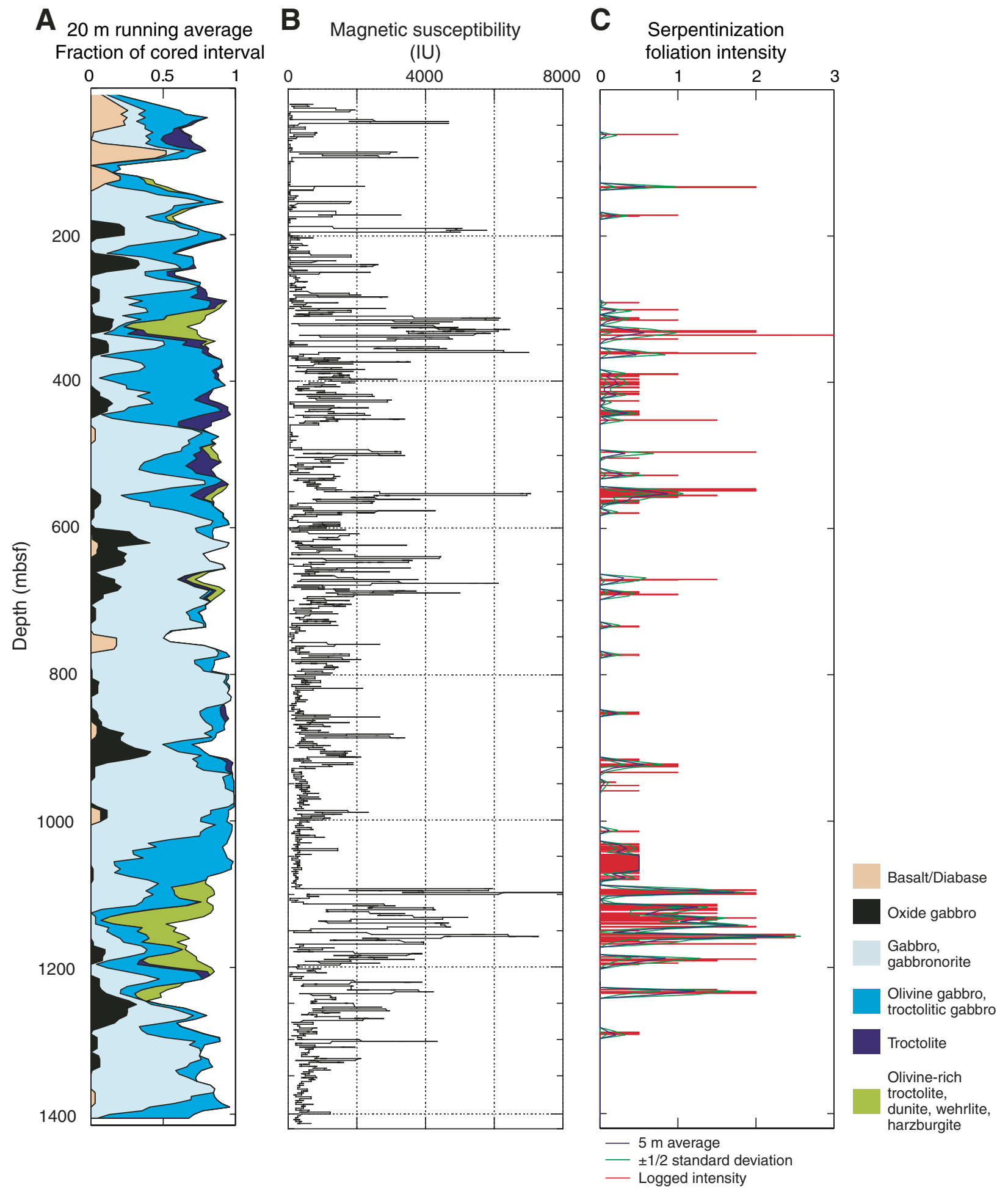


Figure F32. Demagnetization results from two diabase intervals illustrating the difficulty of isolating stable remanence directions in this lithology. In some intervals, a high-stability reversed polarity component is (A) readily identified in the discrete sample but (B) cannot be isolated from the corresponding point in the archive half. In other intervals, a high-stability reversed component is isolated in both (C) discrete sample and (D) archive-half data, but this only represents a small fraction of the natural remanent magnetization (NRM). Open circles $=$ projections of the remanence onto the north-south vertical plane, solid circles $=$ projections of the remanence onto the horizontal plane.

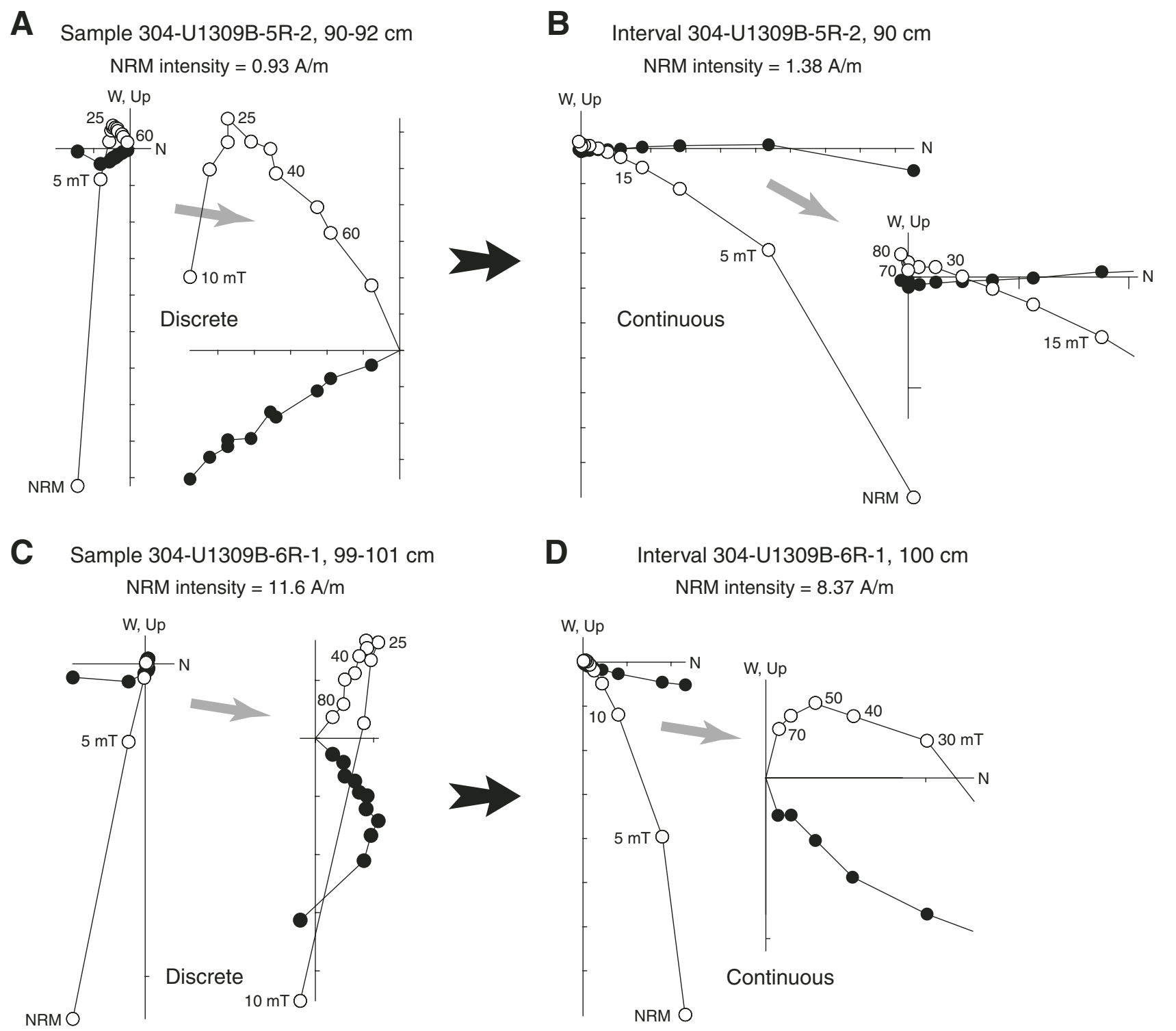


Figure F33. Downhole variations in physical properties in Hole U1309D. A. Lithology. B. Bulk density of core samples. Data from Expedition 304 are not color-coded based on lithology. C. $P$-wave velocity of core samples. D. Bulk density measured by logging. E. $P$-wave velocity measured by logging. F. Electrical resistivity measured by the Dual Laterolog borehole tool.

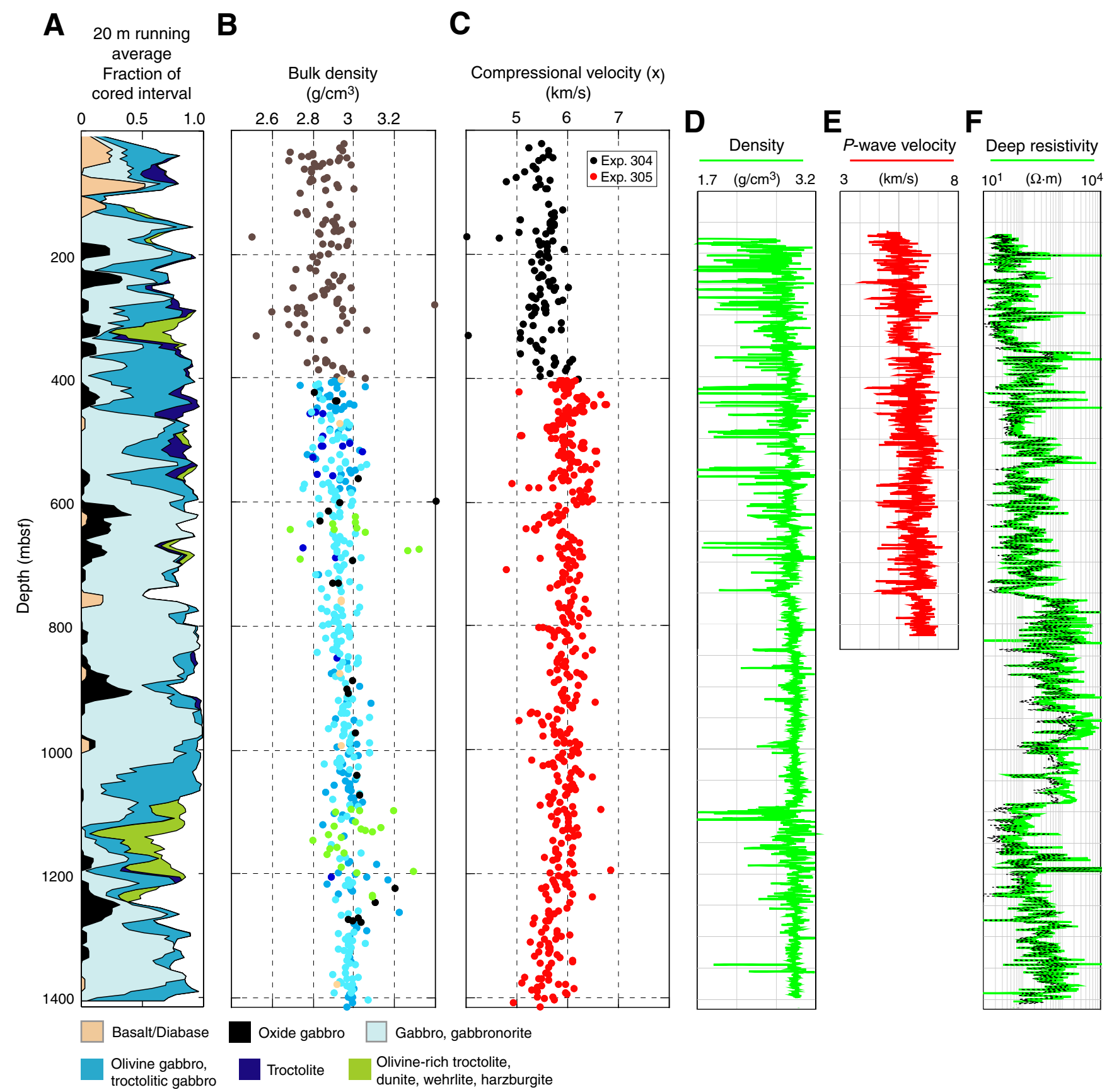


Figure F34. Downhole variation of vein mineralogy plotted with running average of lithology. The overall downcore distribution of veins is relatively homogeneous. Except for a possible occurrence shallow in the hole (not confirmed by XRD or thin section), zeolites first appear near $700 \mathrm{mbsf}$ and then increase regularly to the bottom of the hole. Secondary sulfide minerals are most common in the upper $400 \mathrm{~m}$ of Hole U1309D.

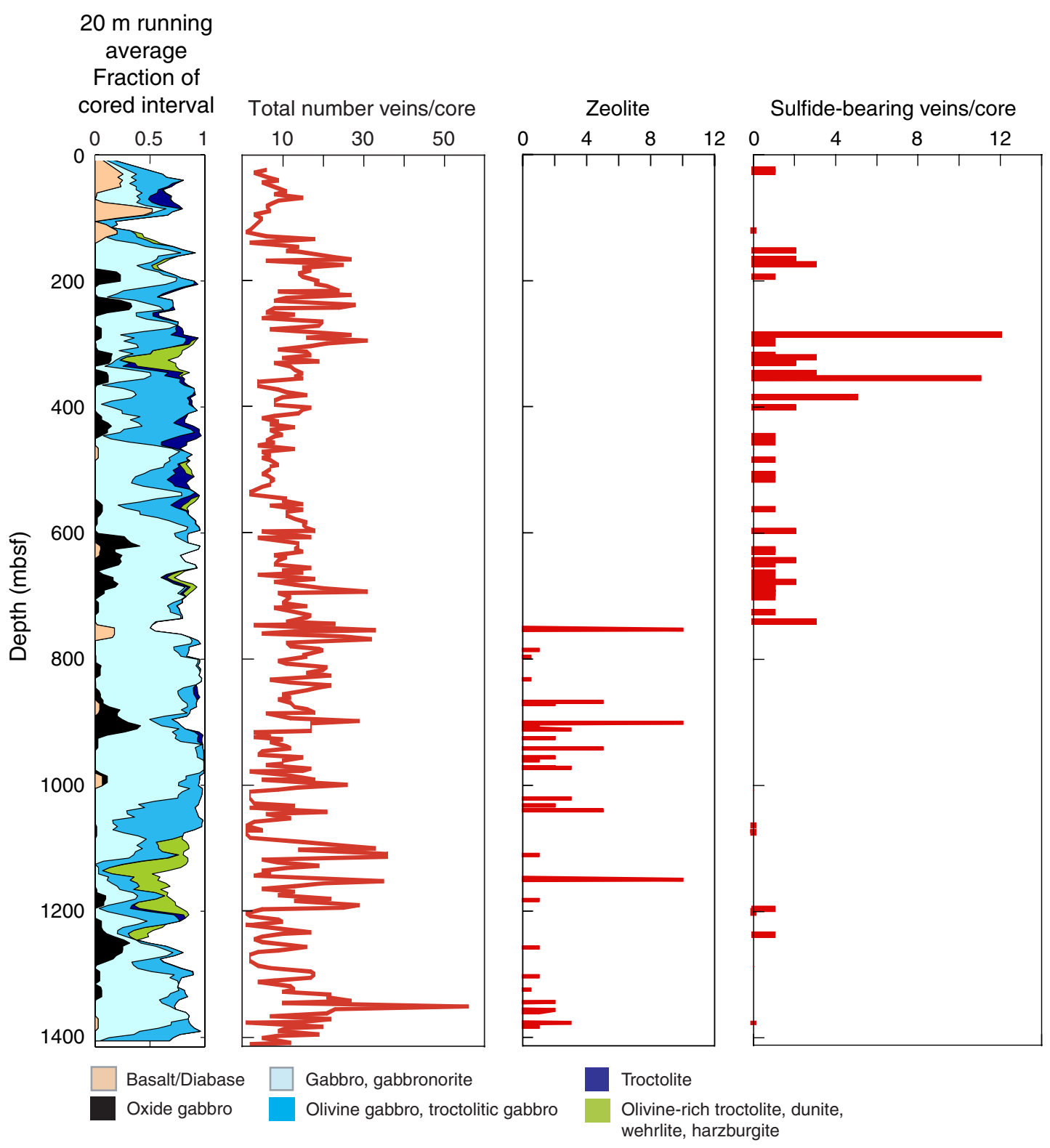


Figure F35. Temperature recorded by the TAP tool. Increase in borehole temperature with time can be seen in downhole versus uphole logging runs and between the main and repeat logging passes. Dashed lines indicate the location of consistent dips in temperature, the lower two of which are located where a fault zone is inferred to occur.

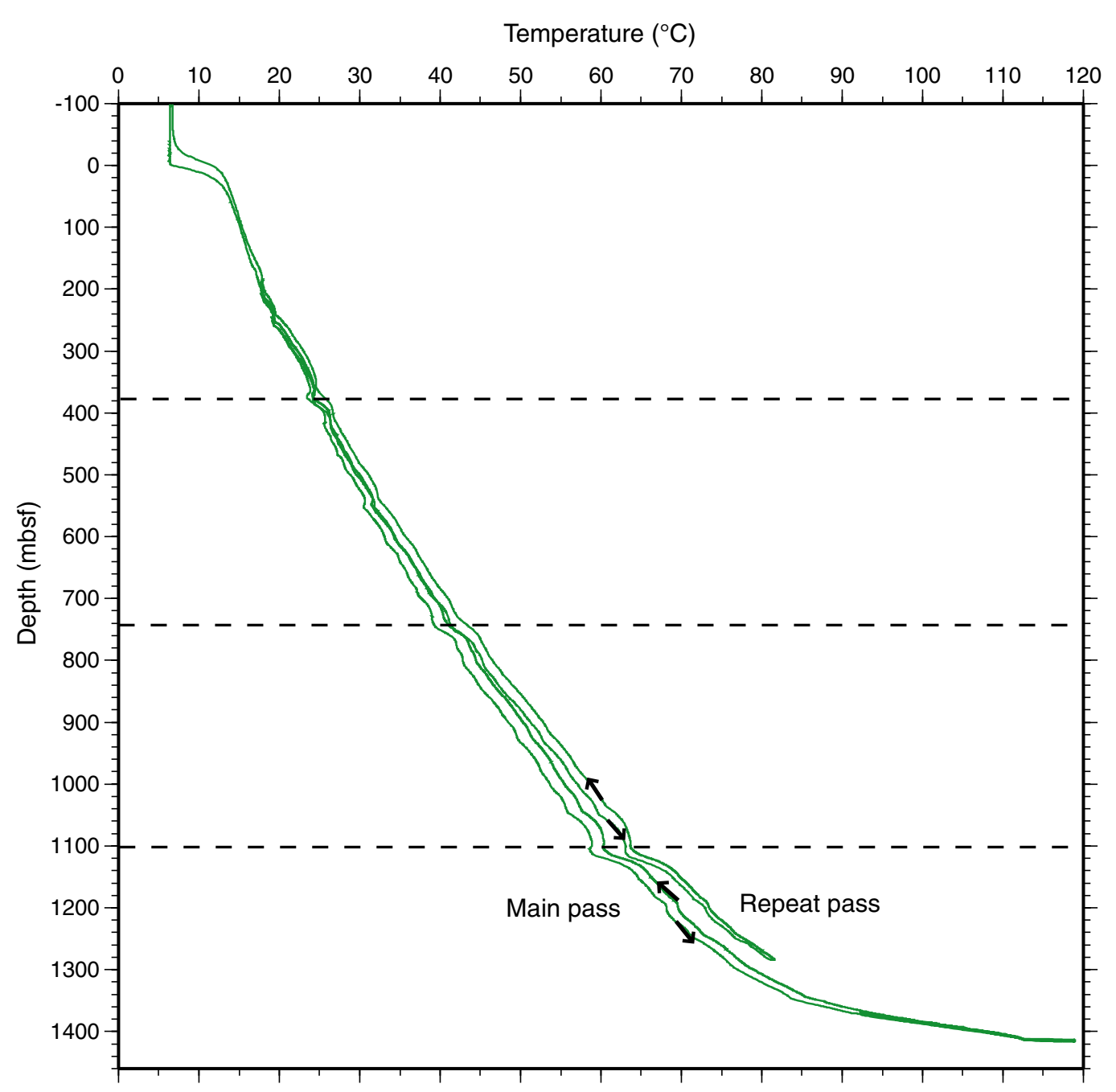

20 m running average

Fraction of cored interval

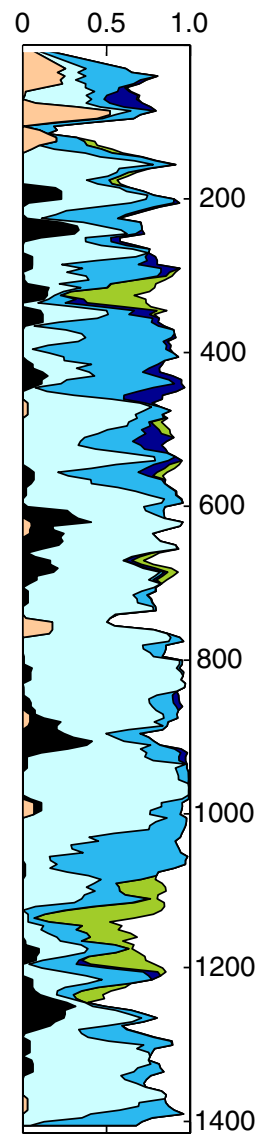

Basalt/Diabase Oxide gabbro Gabbro, gabbronorite

Olivine gabbro, troctolitic gabbro

Troctolite

Olivine-rich troctolite, dunite, wehrlite, harzburgite 
Figure F36. Setting of hanging wall sites. The area shown is $5 \mathrm{~km} \times 3 \mathrm{~km}$; each gridbox $=500 \mathrm{~m}$. Universal Transverse Mercator (UTM) Zone 23 and latitude/longitude coordinates are labeled. Side-scan sonar data are overlain by bathymetric contours (50 m interval), which show the eastern scarp of the hanging wall that drops steeply into the median valley, the relatively gentle topography on the top of the block, and the break in slope from the lower central dome. Sites U1310 and U1311 are both near this inferred contact between the footwall and hanging wall. The side-scan data show several high backscatter features (white) that mark scarps. Several small volcanic mounds can also be recognized from high reflectivity on one side and a small shadow on the other side.

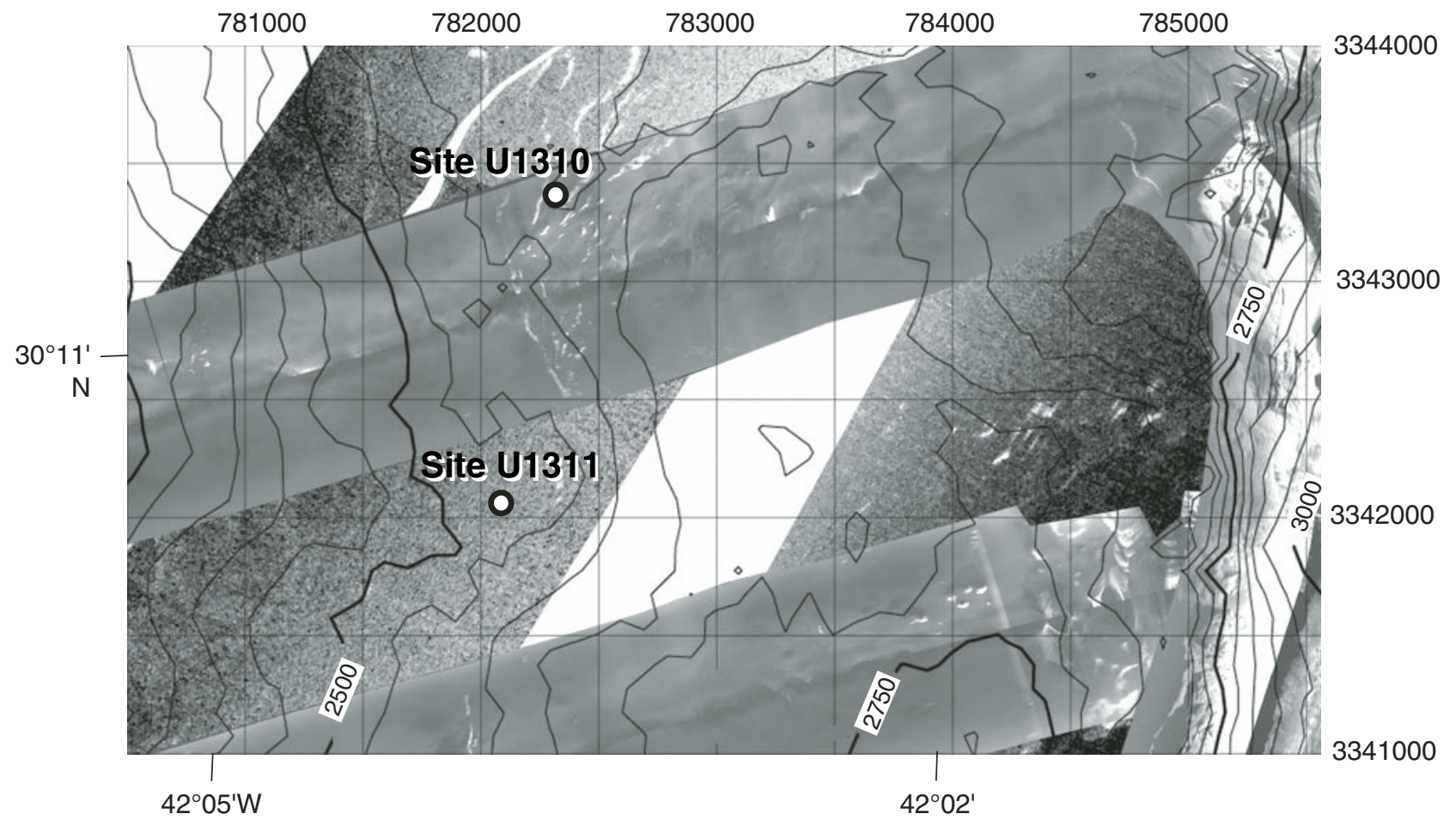


Figure F37. U1311A basalt thin section (Sample 304-1311A-1R-1, 26-29 cm) (field of view $=2 \mathrm{~cm}$; planepolarized light).

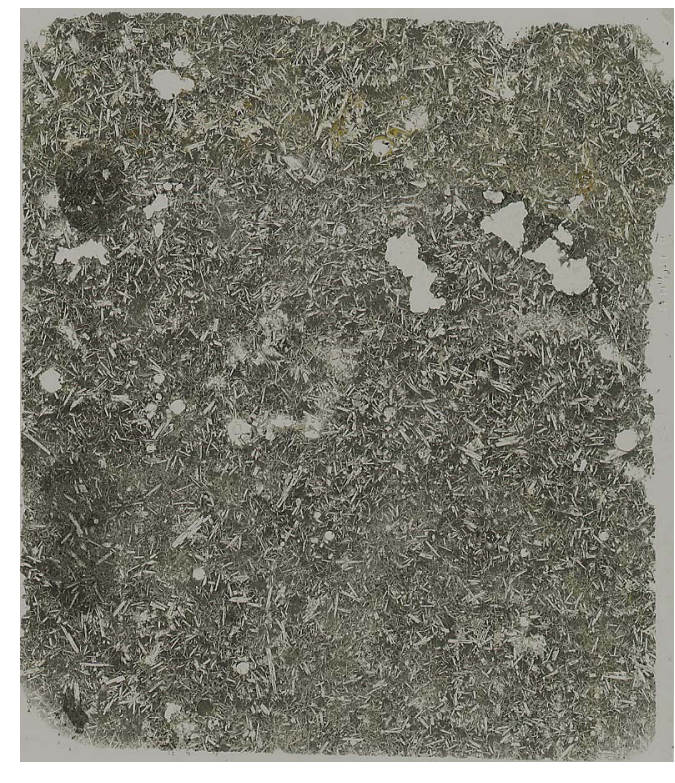

$25 \mathrm{~mm}$ 
Table T1. Expedition 304 and 305 site summaries.

\begin{tabular}{|c|c|c|c|c|c|c|c|c|c|c|c|}
\hline Hole & Latitude & Longitude & $\begin{array}{l}\text { Seafloor } \\
\text { depth } \\
\text { (mbrf) }\end{array}$ & $\begin{array}{l}\text { Cores } \\
(N)\end{array}$ & $\begin{array}{c}\text { Cored } \\
(\mathrm{m})\end{array}$ & $\begin{array}{l}\text { Recovered } \\
(\mathrm{m})\end{array}$ & $\begin{array}{c}\text { Recovery } \\
\text { (\%) }\end{array}$ & $\begin{array}{c}\text { Drilled } \\
(\mathrm{m})\end{array}$ & $\begin{array}{c}\text { Total } \\
\text { penetration } \\
(\mathrm{m})\end{array}$ & $\begin{array}{l}\text { Time on } \\
\text { hole }(h)\end{array}$ & $\begin{array}{c}\text { Time on } \\
\text { hole (days) }\end{array}$ \\
\hline U1309A & $30^{\circ} 10.11^{\prime} \mathrm{N}$ & $42^{\circ} 7.11^{\prime} \mathrm{W}$ & 1653.4 & 1 & 2.0 & 1.9 & 96.0 & 0.0 & 2.0 & 14.75 & 0.6 \\
\hline U1309B & $30^{\circ} 10.11^{\prime} \mathrm{N}$ & $42^{\circ} 7.11^{\prime} \mathrm{W}$ & 1653.4 & 20 & 101.8 & 46.7 & 45.9 & 0.0 & 101.8 & 152.83 & 6.4 \\
\hline U1309C & $30^{\circ} 10.11^{\prime} \mathrm{N}$ & $42^{\circ} 7.12^{\prime} \mathrm{W}$ & 1646.0 & 0 & 0.0 & 0.0 & 0.0 & 6.0 & 6.0 & 47.83 & 2.0 \\
\hline U1309D & $30^{\circ} 10.12^{\prime} \mathrm{N}$ & $42^{\circ} 7.11^{\prime} \mathrm{W}$ & 1656.0 & 294 & 1395.0 & 1043.3 & 74.8 & 20.5 & 1415.5 & 1400 & 59.4 \\
\hline U1309E & $30^{\circ} 10.12^{\prime} \mathrm{N}$ & $42^{\circ} 7.11^{\prime} \mathrm{W}$ & 1656.0 & 1 & 3.8 & 5.6 & 147.4 & 0.0 & 3.8 & 3.25 & 0.1 \\
\hline U1309F & $30^{\circ} 10.20^{\prime} \mathrm{N}$ & $42^{\circ} 7.25^{\prime} \mathrm{W}$ & 1656.0 & 1 & 4.8 & 6.1 & 126.9 & 0.0 & 4.8 & 14.58 & 0.6 \\
\hline U1309G & $30^{\circ} 10.54^{\prime} \mathrm{N}$ & $42^{\circ} 6.32^{\prime} \mathrm{W}$ & 1885.0 & 1 & 3.5 & 0.9 & 26.0 & 0.0 & 3.5 & 16.92 & 0.7 \\
\hline \multirow[t]{2}{*}{$\mathrm{U1309H}$} & $30^{\circ} 10.54^{\prime} \mathrm{N}$ & $42^{\circ} 6.32^{\prime} \mathrm{W}$ & 1885.0 & 1 & 4.0 & 0.2 & 4.8 & 0.0 & 4.0 & 4 & 0.15 \\
\hline & & \multicolumn{2}{|c|}{ Site U1309 totals: } & 319 & 1514.9 & 1104.7 & 72.9 & 26.5 & 1541.4 & 1654.16 & 69.95 \\
\hline U1310A & $30^{\circ} 11.49^{\prime} \mathrm{N}$ & $42^{\circ} 3.93^{\prime} \mathrm{W}$ & 2594.0 & 0 & 0.0 & 0.0 & NA & 12.0 & 12.0 & 115.42 & 4.8 \\
\hline U1310B & $30^{\circ} 11.48^{\prime} \mathrm{N}$ & $42^{\circ} 3.92^{\prime} \mathrm{W}$ & 2594.0 & 2 & 23.0 & 1.3 & 5.7 & 0.0 & 23.0 & 66.67 & 2.8 \\
\hline U1311A & $30^{\circ} 10.61^{\prime} \mathrm{N}$ & $42^{\circ} 4.19^{\prime} \mathrm{W}$ & 2552.0 & 2 & 12.0 & 1.7 & 14.3 & 0.0 & 12.0 & 57.33 & 2.4 \\
\hline \multirow[t]{3}{*}{ U1311B } & $30^{\circ} 10.66^{\prime} \mathrm{N}$ & $42^{\circ} 4.22^{\prime} \mathrm{W}$ & 2516.0 & 0 & 0.0 & 0.0 & 0.0 & 10.6 & 10.6 & 37.42 & 1.6 \\
\hline & \multicolumn{3}{|c|}{ Site U1310 and U1311 totals: } & 4 & 35 & 3.0 & 8.6 & 22.6 & 57.6 & 276.8 & 11.5 \\
\hline & \multicolumn{3}{|c|}{ Expedition 304 and 305 totals: } & 323 & 1549.9 & 1107.7 & 71.5 & 49.1 & 1599 & 1930.96 & 81.45 \\
\hline
\end{tabular}

Notes: Time on hole includes logging. NA = not available. 